Doctoral (Ph.D.) Dissertation

\title{
Free Radical-Initiated Unfolding of Peptide Secondary Structure Elements
}

By: Michael Christopher Owen, M.Sc.

Supervisor: Béla Viskolcz

Chemistry Doctoral School

Department of Chemical Informatics

2012

Szeged, Hungary 
TABLE OF CONTENTS

ABSTRACT

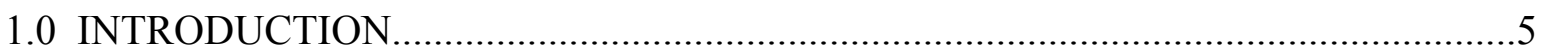

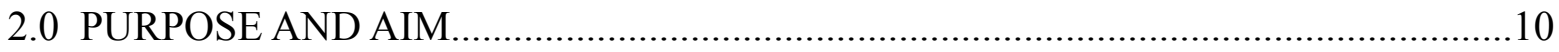

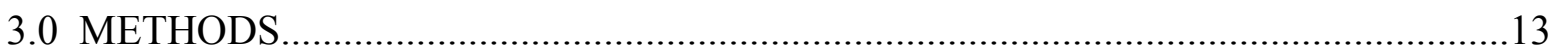

3.1 Computing the Potential Energy Surfaces............................................................13

3.2 Computing the Unfolding of the Pentapeptides......................................................16

3.3 Parameterization of the Gly" and Ala* Force Fields................................................18

3.4 Molecular Dynamics Simulations of the Ala Heptapeptide.....................................20

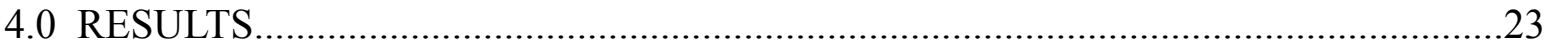

4.1 General Features of the Amino Acid Potential Energy Surfaces..............................23

4.2 Hydrogen Abstraction from Monopeptides.............................................................27

4.2.1 The Potential Energy Surfaces................................................................27

4.2.2 Hydrogen Abstraction Reaction Coordinates............................................29

4.3 Structural Analysis of the Pentapeptides...............................................................

4.3.1 Comparison of the G5 to the G5 Peptide Radicals....................................42

4.3.2 Comparison of the A5 to the A5 Peptide Radicals....................................48

4.4 Thermodynamic Analysis of the Pentapeptides......................................................54

4.4.1 Hydrogen Atom Abstraction from G5........................................................5

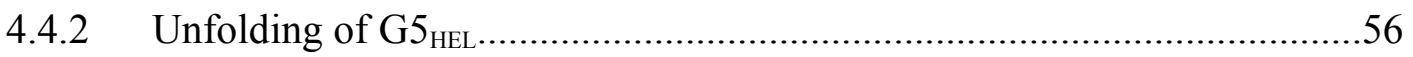

4.4.3 Reactions of G5 with the Reactive Oxygen Species...................................57

4.4.4 Hydrogen Atom Abstraction from A5 .........................................................58

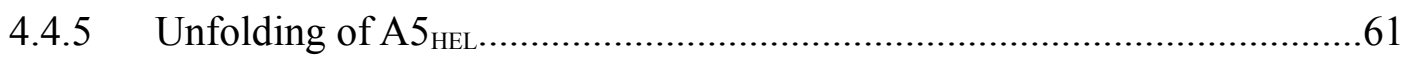

4.4.6 Reactions of A5 with the Reactive Oxygen Species..................................62

4.5 Molecular Dynamics Simulations of Heptapeptides....................................................64

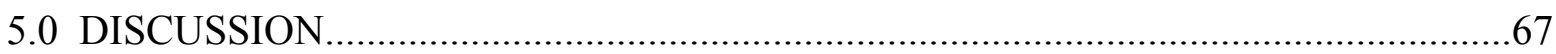

5.1 Consequences of $\mathrm{C}_{\alpha}$ Radical Formation on Monopeptide Confomers............................67

5.2 Hydrogen Abstraction from the Monopeptides.........................................................68

5.3 Deviations from the G5 and A5 Structures............................................................

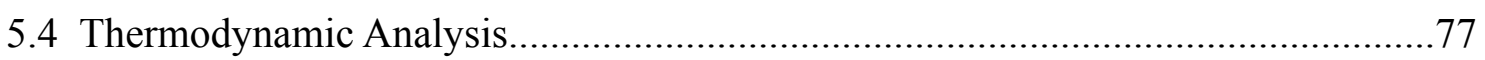

5.4.1 Hydrogen Abstraction Energy and Peptide Radical Stability.......................77

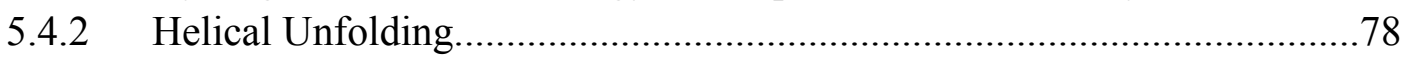

5.4.3 Reactions of G5 and A5 with Reactive Oxygen Species.............................79

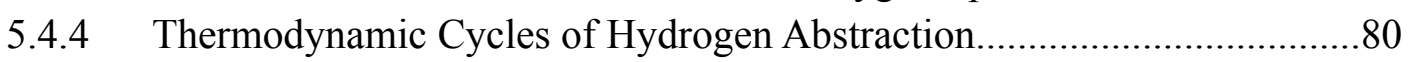

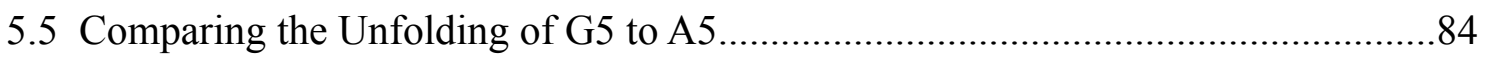

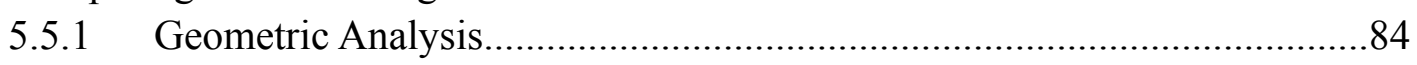

5.5.2 Thermodynamic Analysis.........................................................................

5.6 Comparing the MD Simulation to the Potential Energy Surfaces...............................85

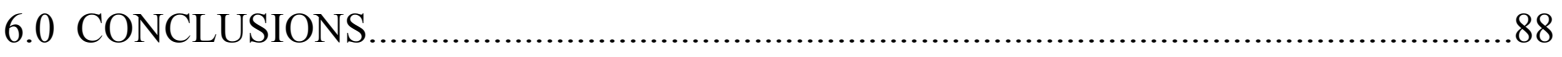

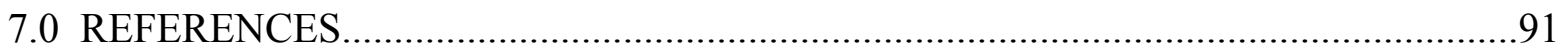

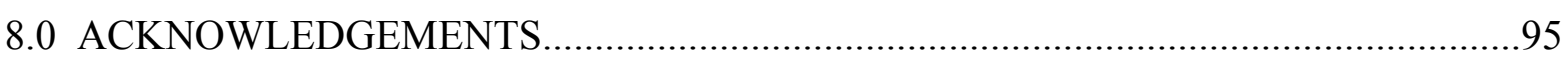

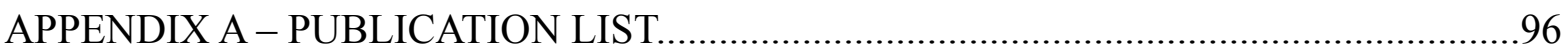




\section{$\underline{\text { ABSTRACT }}$}

The present thesis investigates the effect of radical formation on peptide secondary structure elements, and analyses the changes such radical formations can induce.

To determine if the pro- $\mathrm{L}$ hydrogen on $\mathrm{C}_{\alpha}$ of the glycyl residues are more prone to hydrogen abstraction by ${ }^{\circ} \mathrm{OH}$ than the respective hydrogen in Ala, the pre-reaction van der Waals complexes, transition states, and post-reaction van der Waals complexes of $\mathrm{H}$ abstraction from Ala and Gly were computed. To evaluate the conformational effect of $\mathrm{H}$ abstraction, different conformers $\left(\beta_{\mathrm{L}}, \gamma_{\mathrm{L}}, \gamma_{\mathrm{D}}, \alpha_{\mathrm{L}}\right.$ and $\left.\alpha_{\mathrm{D}}\right)$ of these residues were studied. These calculations were carried out at the MPWKCIS1K/6-311++G(3df,2p)//BHandHLYP/6$311+G(d, p)$ level of theory.

To study the effect of hydrogen abstraction on peptide secondary structures, model pentapetides were also studied. Helical unfolding (as shown in Figure 1) was investigated by computing the thermodynamic functions of the radical-initiated unfolding of a helix. A hydrogen atom was extracted from the $\mathrm{C}_{\alpha}$ and amide nitrogen of $\mathrm{Gly}^{3}$, and the $\mathrm{C}_{\alpha}, \mathrm{C}_{\beta}$ and amide nitrogen of Ala ${ }^{3}$, of the respective G5 ( $N$-Ac-GGGGG-NH$\left.)_{2}\right)$ and A5 ( $N$-Ac-AAAAA$\mathrm{NH}_{2}$ ) homo-peptides. The $\mathrm{HO}^{*}, \mathrm{HO}_{2}{ }^{-}$and $\mathrm{O}_{2}{ }^{-}$radicals were used in each case, and the thermodynamic functions were computed using the B3LYP density functional. The changes in potential energy, standard enthalpy, Gibbs free energy and entropy during these reactions were computed with G5 and A5 in the $3_{10}$-helical and fully-extended conformations. These computations were carried out in the gas phase and the effect of solvent was mimicked with the C-PCM implicit water model.

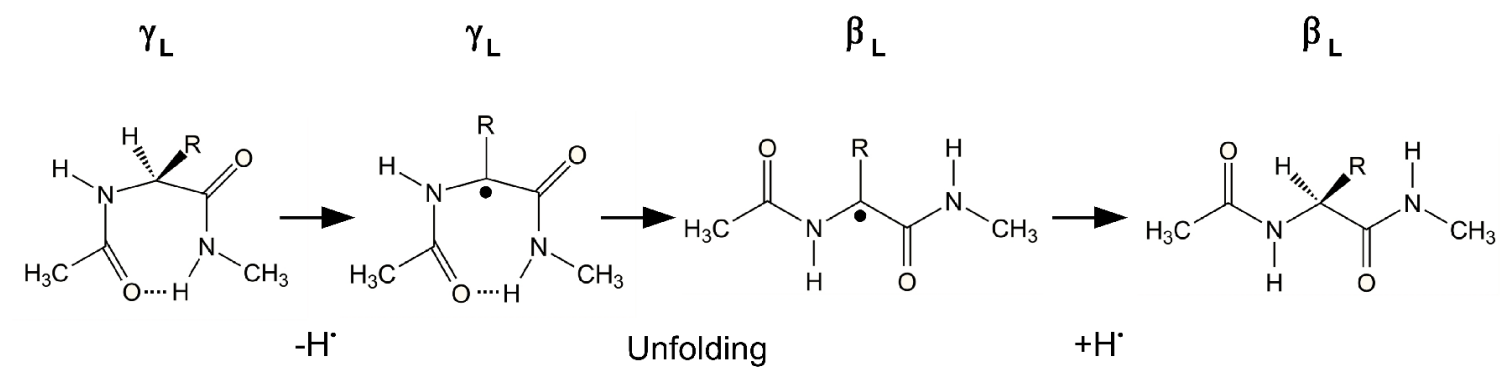

Figure 1. A schematic representation of the radical-initiated unfolding of an amino acid residue. 
To enable the effects of $\mathrm{C}_{\alpha}$-centered radicals to be studied in longer peptides and proteins over greater time intervals with molecular dynamics (MD), force field parameters for the $\mathrm{C}_{\alpha^{-}}$ centered Ala radical were developed for use with the OPLS force field. This was done by minimizing the sum of squares deviation between the quantum chemical and OPLS-AA energy hypersurfaces. These parameters were used to determine the effect of the $\mathrm{C}_{\alpha}$-centered Ala radical on the structure of a hepta-alanyl peptide in molecular dynamics simulations.

A dramatic change in conformation is observed in the Gly and Ala conformers after converting to $\mathrm{Gly}^{\circ}$ and $\mathrm{Ala}$, respectively, and this change can be monitored along the minimal energy pathway by computing the intrinsic reaction coordinate for the conformers of each residue. The $\beta_{\mathrm{L}}$ conformer of Gly and Ala form the lowest-lying transition states, whereas the side-chain of Ala strongly destabilizes the $\alpha$ conformers compared to the $\gamma$ conformers. The energies of the $\alpha$ to $\gamma$ transition in Gly are more similar than those of Ala. This effect shown in Ala could inhibit the abstraction of hydrogen from the chiral amino acid residues in the helices. The energy of a subsequent hydrogen abstraction reactions between Ala ${ }^{\circ}$ and Gly and $\mathrm{H}_{2} \mathrm{O}_{2}$ remains approximately $90 \mathrm{~kJ} \mathrm{~mol}^{-1}$ below the entrance level of the ${ }^{\circ} \mathrm{OH}$ reaction, indicating that the ${ }^{\circ} \mathrm{OH}$ radical can initiate an $\alpha$ to $\beta$ transition in an amino acid. However, a molecule such as $\mathrm{H}_{2} \mathrm{O}_{2}$ must provide the hydrogen atom necessary to reform the Gly and Ala residues.

As shown in the G5 and A5 peptides, hydrogen abstraction is the most favorable at the $\mathrm{C}_{\alpha}$, followed by the $\mathrm{C}_{\beta}$, then amide nitrogen. The secondary structure has a strong influence on the bond dissociation energy of the $\mathrm{H}-\mathrm{C}_{\alpha}$, but a negligible effect on the dissociation energy of the $\mathrm{H}-\mathrm{CH}_{2}$ and $\mathrm{H}-\mathrm{N}$ bonds. The $\mathrm{HO}^{\circ}$ radical is the strongest hydrogen abstractor, followed by $\mathrm{HO}_{2}{ }^{\circ}$ and finally $\mathrm{O}_{2}^{-}$. Secondary structure elements, like H-bonds in the 310 -helix, protect the peptide from radical attack by hindering the potential electron delocalization at the $\mathrm{C}_{\alpha}$ which is present when the peptide is in the extended conformation. The $\mathrm{C}_{\alpha}$-centered pentapeptide radicals have a significantly higher propensity to unfold than the closed shell pentapeptides. Furthermore, only the $\mathrm{HO}^{\circ}$ radical can initiate the unfolding of the pentapeptides to an extended pentapeptide radical, and the unfolding of the $\mathrm{C}_{\alpha}$-centered $\mathrm{G} 5$ is 
more favorable than the unfolding of the $\mathrm{C}_{\alpha}$-centered A5.

A negligible sum-of-squares energy deviation was observed in the stretching parameters, and the newly-developed OPLS-AA torsional parameters showed a good-agreement with the LMP2/cc-pVTZ(-f) hypersurface. The MD simulations showed planar conformations of the residue with the radical on its alpha carbon (Alr) are preferred and these conformations increase the formation of $\gamma$ - $\alpha$ - and $\pi$-turn structures depending on the position in the turn occupied by the Alr residue. Higher-ordered structures are destabilized by Alr except when this residue occupies position " $i+1$ " of the $3_{10}$-helix.

These results offer new insight in to the protein-misfolding mechanisms initiated by Habstraction from the $\mathrm{C}_{\alpha}$ of peptide and protein residues. 


\subsection{INTRODUCTION}

\subsection{General Implication of Oxidative Stress}

$\mathrm{O}_{2}$ is the terminal electron acceptor in the oxidation of carbon fuels to generate ATP by oxidative phosphorylation. However, the physiological role of $\mathrm{O}_{2}$ is not limited to energy metabolism. The metabolism of sterols, indoles, alkaloids, antibiotics and some detoxifying pathways are also $\mathrm{O}_{2}$-dependent. ${ }^{1}$ The metabolic analysis of 70 genomes suggested that $\mathrm{O}_{2}$ is directly or indirectly associated with over a thousand metabolic reactions not associated with anaerobes. $^{2}$ In aerobic organisms, the synthesis of mono-unsaturated fatty acids, tyrosine and nicotinic acid are $\mathrm{O}_{2}$-dependent. ${ }^{3}$

A general consequence of $\mathrm{O}_{2}$-dependent biosynthesis and aerobic respiration is the production of reactive oxygen species (ROS). When the amount of ROS in the body reaches an elevated state, significant structural modification can be observed in biological macromolecules. This state is known as 'oxidative stress', and result in loss of function and degradation. Oxidative stress is a common feature in the mechanisms that cause carcinogenesis, tumor promotion, Parkinson's disease, Alzheimer's disease and is also implicated in the ageing process. ${ }^{4-9}$

The superoxide radical anion $\left(\mathrm{O}_{2}^{-*}\right)$, the perhydroxyl radical $\left(\mathrm{HO}_{2}{ }^{\circ}\right)$ and the hydroxyl radical $\left({ }^{\circ} \mathrm{OH}\right)$ comprise the biologically relevant oxygen radicals. ${ }^{10}$ Hydrogen peroxide $\left(\mathrm{H}_{2} \mathrm{O}_{2}\right)$ is another biologically active oxygen species. Superoxide is formed when the groundstate $\mathrm{O}_{2}$ molecule accepts a single electron into one of its $\pi^{*}$ anti-bonding orbitals and is formed in almost all aerobic cells. ${ }^{11}$ The addition of the subsequent electron forms the 
peroxide ion $\left(\mathrm{O}_{2}^{2-}\right)$ which has no unpaired electron and is not a radical, and readily accepts two protons to form $\mathrm{H}_{2} \mathrm{O}_{2}$. Homolytic cleavage of the $\mathrm{O}-\mathrm{O}$ bond in $\mathrm{H}_{2} \mathrm{O}_{2}$ produces two hydroxyl radicals. It has been shown that ${ }^{\circ} \mathrm{OH}$ can be produced by heat, ionization radiation or in several reactions with $\mathrm{Fe}^{2+} .{ }^{12}$ The hydroxyl radical reacts at an extremely high rate with carbohydrates, amino acids, phospholipids, DNA bases and organic acids. ${ }^{12} \mathrm{HO}_{2}{ }^{\circ}$ is produced in reactions between $\mathrm{H}^{\cdot}$ and $\mathrm{O}_{2}$, however $\mathrm{HO}_{2}{ }^{\circ}$ has a $\mathrm{pK}_{\mathrm{a}}$ of 4.8 , therefore the biological significance of this radical may be limited. ${ }^{11}$

Reactive oxygen species can oxidize lipids or DNA, and form glycation end-products. However, proteins form by far the largest mass of oxidizable organic components of living matter. ${ }^{13-16}$ Free radicals have been shown to induce the formation of bi-tyrosine induced protein aggregates, increase the rate of protein fragmentation and increase the susceptibility of proteins to degradation. ${ }^{10,17}$ The formation of protein carbonyls has become the marker used to identify proteins that have been damaged by oxidative stress. ${ }^{18,19}$ All amino acids are susceptible to modification by both ${ }^{\circ} \mathrm{OH}$ and ${ }^{\circ} \mathrm{OH}+\mathrm{O}_{2}^{-{ }^{-}}$, however tryptophan, tyrosine, histidine and cysteine showed greater sensitivity and the rate of oxidation depended on the concentration of the ROS. Moreover, it was suggested that ${ }^{\circ} \mathrm{OH}$ is the primary radical responsible for all amino acid modifications and that $\mathrm{O}_{2}^{-}$and $\mathrm{O}_{2}$ can further transform the products of ${ }^{\circ} \mathrm{OH}$ reactions. ${ }^{18,20-22}$ A decrease in protein solubility, used as a measure of protein unfolding, was also shown in the presence of ${ }^{\circ} \mathrm{OH}$ in a dose-dependent manner, which was also exacerbated in the presence of $\mathrm{O}_{2}$ and $\mathrm{O}_{2}{ }^{-23}$

\subsection{Basic Structural Properties of Peptides}


$A b$ initio and DFT methods, once limited to small molecules, are becoming practical for use on peptides and peptide analogues. The use of $\mathrm{N}$-Ac- and -NHMe protection groups for the $\mathrm{N}$ and $\mathrm{C}$ termini, respectively, allows an amino acid residue to be studied in a local environment comparable to that of a peptide. ${ }^{23}$ This method can be used to accurately calculate the relative energies of two or more systems, allowing the relative stabilities of different secondary structures to be determined.

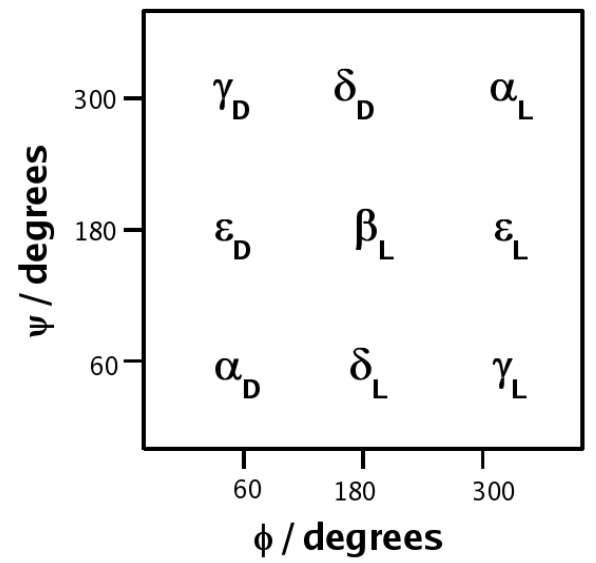

Figure 2. The symbols used to describe the conformations of an amino acid residue and their corresponding $\phi$ and $\psi$ angles.

The conformation of an amino acid residue can be described by its $\phi$ and $\psi$ angles. The relationship between $\phi$ and $\psi$ angles and conformation are described in Figure 2. The Greek letters originate from an older nomenclature, involving $\alpha, \beta, \gamma$, and $\varepsilon$ for an $\alpha$-helix, $\beta$-sheet, $\gamma$-turn, and $\varepsilon$ for the polyproline II conformations, respectively, while the L and D subscripts indicate the conformations favored by the $\mathrm{L}$ and $\mathrm{D}$ configurations of amino acids. ${ }^{25}$ This scheme will be used to describe the conformations of the peptide structures in this work.

In the search of a subset of the protein data bank, it was observed that the $3_{10}$-helix occurs less frequently than the $\alpha$-helix in regions that are greater than 5 residues, but is more 
prevalent in regions containing 5 residues or less. ${ }^{26,27}$ Also, $3_{10}$-helices are considered to be sequential type III $\beta$-turns, therefore the occurrence of these structures can be underestimated. $^{28,29}$ These short $33_{10}$-helices can be crucial motifs which mediate the conformational transitions of proteins..$^{30-32}$ It has been observed that $3_{10}$-helices are an intermediate structure in the conversion of $\alpha$-helices to $\beta$-sheets in amyloid fibrils, and this has been shown to be initiated by free radicals. ${ }^{33}$ The aim of this study is to understand how free radicals initiate the unfolding of the $3_{10}$-helix to an extended conformation.

\subsection{Parameterization of the $\mathrm{Gly}^{\bullet}$ and Ala ${ }^{*}$ Force Fields}

The OPLS-AA force field is a Class I force-field according to the generally accepted force-field classification criteria and is widely accepted for simulations of structures of peptides and proteins in solution. ${ }^{34-36}$ The energy of a molecule at a particular geometry can be described with the OPLS-AA/L force field using Equation 1. The energy of the same

$$
\begin{gathered}
E_{i}^{M M}=\sum_{\text {bonds }} K_{r}\left(r-r_{0}\right)^{2}+\sum_{\text {angles }} K_{\Theta}\left(\Theta-\Theta_{0}\right)^{2} \\
+\sum_{\text {torsions }}\left(\frac{V_{1}^{k}}{2}\left[1+\cos \left(\phi_{i}\right)\right]+\frac{V_{2}^{k}}{2}\left[1-\cos \left(2 \phi_{i}\right)\right]+\frac{V_{3}^{k}}{2}\left[1+\cos \left(3 \phi_{i}\right)\right]\right) \\
+\sum_{k<l}\left(\frac{q_{k} q_{l} e^{2}}{r_{k l}}+4 \epsilon_{k l}\left(\frac{\sigma_{k l}^{12}}{r_{k l}^{12}}-\frac{\sigma_{k l}^{6}}{r_{k l}^{6}}\right)\right)
\end{gathered}
$$

molecule at the same geometry can be computed using quantum mechanics and yield the

$E_{i}^{Q M}$ energy described in Equation 2, where $\hat{H}$ is the molecular Hamiltonian and $\boldsymbol{\Psi}$ is the wave function:

$$
\hat{\mathrm{H}}_{\mathrm{i}} \Psi=\mathrm{E}_{\mathrm{i}}^{\mathrm{QM}} \Psi
$$


The quantum mechanical energy can be used to develop molecular mechanical parameters by fitting the mechanical hyper-surface to the values obtained using quantum mechanics, as initially described by Lifson and Warshel. ${ }^{37}$ In this method, the molecular mechanics parameter-dependent sum of squares distances between the selected points on these two hyper-surfaces are minimized. In this work, the experimental values were replaced with the computed energy values as a function of the geometrical parameters. 


\subsection{PURPOSE AND AIM}

The presence of the methyl side chain of the alanyl (Ala, A) residue could be the reason for the difference in the kinetics of hydrogen abstraction reactions between ${ }^{\circ} \mathrm{OH}$ and the respective glycyl (Gly, G) and Ala residues. To see if this is the case, the influence of the methyl side chain of Ala on the stability of the Gly- ${ }^{-} \mathrm{OH}$ and Ala- ${ }^{-} \mathrm{OH}$ pre-reaction complexes, transition states, and post-reaction complexes will be determined. This will reveal the extent to which steric hindrance inhibits hydrogen abstraction and also determines which conformations enable or inhibit the progress of the reaction. Moreover, the structural perturbations induced by hydrogen abstraction from two model pentapeptides will be investigated. The B3LYP density functional will be used to compare the geometries of $N$-AcAAAAA- $\mathrm{NH}_{2}$ and $N$-Ac-GGGGG-NH$H_{2}$ peptides with radicals centered at the $\mathrm{C}_{\alpha}, \mathrm{C}_{\beta}$ and amide nitrogen atoms of the third Ala residue $\left(\mathrm{Ala}^{3}\right)$, and the $\mathrm{C}_{\alpha}$ and amide nitrogen of the third Gly residue $\left(\mathrm{Gly}^{3}\right)$ to that of the respective third residue of the closed-shell peptides.

Density functionals have been shown to lead to accurate predictions for the energetics of $\mathrm{H}$-atom abstraction reactions and have also been shown to compute geometries that are in good agreement with experimentally determined values. ${ }^{38,39}$ The penta-alanyl helix was chosen because Ala is the smallest amino acid residue that is able to stabilize the conformations preferred by L-amino acids, and its small size causes a small entropy loss during helix formation. ${ }^{40}$ On the basis of X-ray crystallographic data, the frequency at which Gly is found at the $3^{\text {rd }}$ position of the type-III $\beta$-turns is among the highest of all the amino acid residues. ${ }^{41}$ Since Gly is the only achiral amino acid residue used for protein synthesis, it 
is important to investigate the unfolding properties of this residue.

Quantum chemical calculations have been shown to elucidate mechanisms of free radical-initiated oxidation of amino acids and peptide analogues..$^{24,42-47}$ One of many peptide radical structures and reaction intermediates, the $\mathrm{C}_{\alpha}$-centered radical is of particular interest because it is common to all of the amino acid residues and is stabilized by the capto-dative effect. $^{48-50}$ In quantum chemical studies of pentapeptides, it has been determined that peptides with $\mathrm{C}_{\alpha}$-centered radicals have a higher propensity to unfold to the $\beta$ conformation..$^{51,52}$ The number of atoms in the pentapeptide is near the upper limit for quantum chemical studies, and this technique is best-applied near potential energy critical points, using time-independent techniques. In order to determine the effect of $\mathrm{C}_{\alpha}$-centered radicals on the structure of large and dynamic systems, force-field parameters for $\mathrm{C}_{\alpha}$-centered Gly and Ala radicals will be developed. The use of these systems will enable it to be

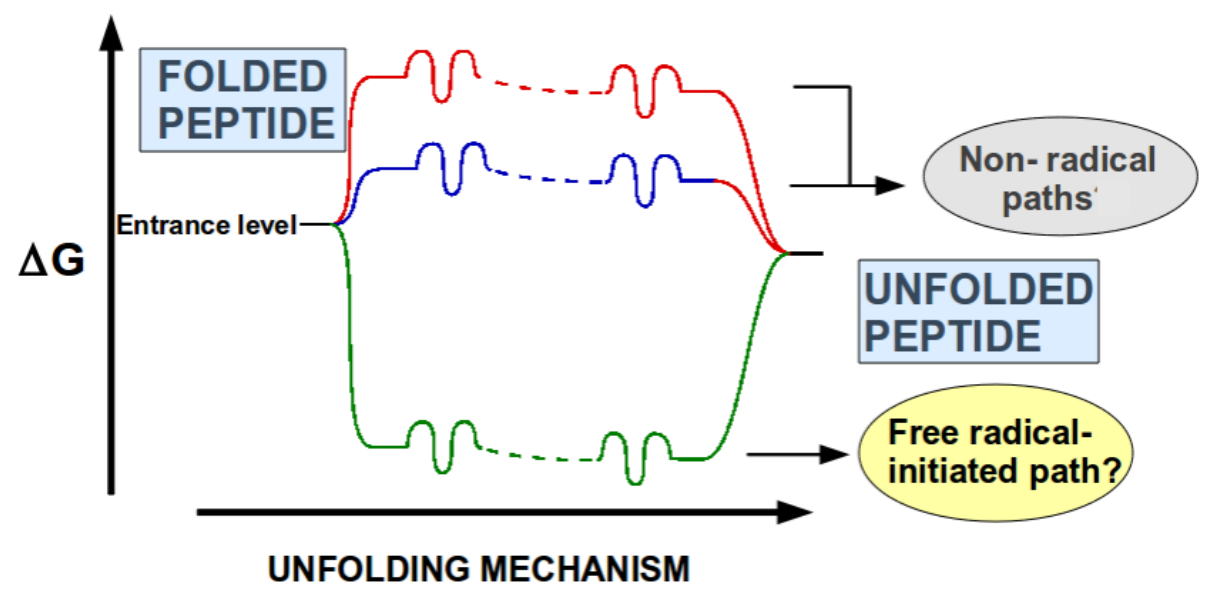

Figure 3. The central question of this work: does radical initiated unfolding of peptides occur through a lower energy path than unfolding without free radical initiation?

determined whether a free radical can initiate the unfolding of a peptide. This scheme is 
illustrated in Figure 3. The changes to the structure of these peptides will be determined using the methods described in the subsequent section. 


\subsection{METHODS}

\subsection{Computing the Potential Energy Surfaces}

\subsubsection{Determining the General Features of the Potential Energy Surfaces}

The Jaguar $5.5^{\circledR}$ software package was used to determine the general features of the potential energy surfaces. The $N$-Ac-Gly-NHMe and $N$-Ac-Gly-NHMe molecules were constructed using a previously described Z-matrix method. ${ }^{25}$ To generate a PES, $\phi$ and $\psi$ angles were independently constrained at $30^{\circ}$ intervals starting at $\phi$ and $\psi=0^{\circ}$, and all other variables were fully relaxed during geometry optimization. This procedure generated 144 conformers on each PES. Geometry optimizations, using the ab initio method at the HF/3$21 \mathrm{G}$ and then $\mathrm{HF} / 6-31 \mathrm{G}(\mathrm{d}, \mathrm{p})$ levels of theory, provided the input structures for the final optimization using DFT at the B3LYP/6-31G(d,p) level of theory, both in vacuo and in a simulated aqueous environment. The aqueous environment was mimicked with a selfconsistent reaction field method, using a Poisson-Boltzmann solver as incorporated in Jaguar $5.5^{\circledR} .53,54$ Water was represented with a dielectric constant of 80.37 and a probe radius of $1.40 \AA \AA$.

\subsubsection{Obtaining the Conformers of Gly, Gly', Ala, Ala ${ }^{\bullet}$ for the $\mathrm{H}$ Abstraction Reaction Coordinates}

The subsequent computations were completed with the Gaussian 09 program package. ${ }^{55}$ The $\phi$ and $\psi$ angles of $N$-Ac-Ala-NHMe (Ala), $N$-Ac-Ala-NHMe (Ala ${ }^{\circ}$ ), $N$-Ac-Gly-NHMe (Gly) and $\mathrm{N}$-Ac-Gly-NHMe (Gly) were rotated in $30^{\circ}$ increments to produce 144 conformations for each residue, which were then energy minimized using the Becke three- 
parameter Lee-Yang-Parr (B3LYP) density functional, with the 6-31G(d) basis set. ${ }^{56-58}$ The potential energy values as a function of the $\phi$ and $\psi$ angles were plotted to construct the potential energy surfaces of Ala, Ala’, Gly and Gly diamides (Figure 4).

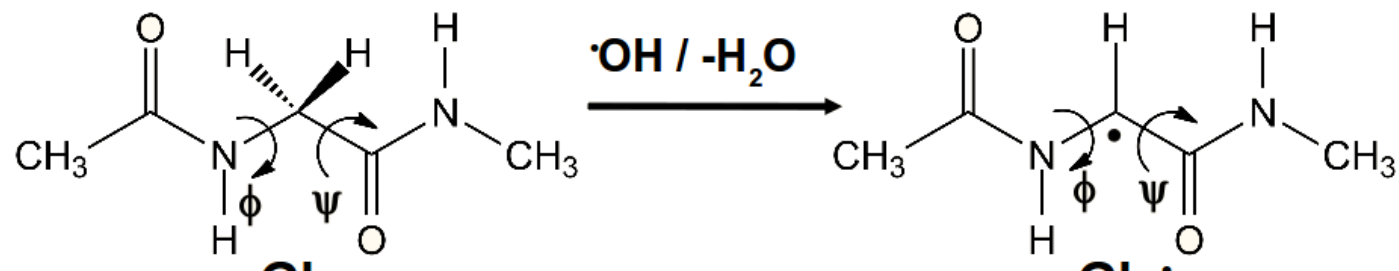

Gly<smiles>CNC(=O)[C@@H](C)[C@@H](O)NC(C)=O</smiles>

Ala<smiles>CNC(=O)CC(C)C(=O)NC(C)=O</smiles>

Ala'

Figure 4. The Gly, Gly', Ala and Ala diamide structures. The $\phi$ and $\psi$ angles which were the dependent variables for the potential energy surfaces are also shown.

Each of the minima of the potential energy surfaces were subsequently optimized using the Berny algorithm at the BHandHLYP/6-311+G(d,p) level of theory and were confirmed as such by asserting that none of the calculated frequencies were imaginary. ${ }^{59,60}$ The standard free energy correction $\left(\mathrm{G}^{\circ}\right)$, enthalpy correction $\left(\mathrm{H}^{\circ}\right)$ and entropy $\left(\mathrm{S}^{\circ}\right)$ were also computed at this level of theory. The MPWKCIS1K/6-311++G(3df,2p) level of theory was used to compute the potential energy of the structures. ${ }^{61}$ The pre-reaction and post-reaction complexes were found by minimizing the transition state structure along the intrinsic reaction coordinate in the reverse and forward directions, respectively. The ability of the MPWKCIS1K and BHandHLYP functionals to reproduce the activation energies computed 
with the G3MP2B3 method was compared by using the $6-311+G(d, p)$ and $6-311++G(3 d f, 2 p)$ basis sets. ${ }^{62}$ An implicit solvent using the conductor-like polarizable continuum model (CPCM) for water with a dielectric constant of $\varepsilon=78.39$ was used for all calculations to mimic an aqueous solvent and all of the optimizations were fully relaxed. ${ }^{63}$

The main disadvantage of the self-consistent reaction field (SCRF) method is the absence of explicit water molecules. In an attempt to account for this simplification, the dielectric coefficient is used to account for the "average" of the ensemble of possible hydrogen bonds between the solvent and solutes and to account for the different electrostatic environments that can surround a peptide when exposed to water. Previous benchmark calculations indicate that the BHandHLYP functional yields geometries and energy values that are in good agreement with results obtained by experiment and high level (G3MP2B3) $a b$ initio methods, which in turn give results that are in excellent agreement with experimentally-derived results in radical systems..$^{38,65-67}$ Moreover, the MPWKCIS1K functional yields hydrogen abstraction barrier height energy values that are in excellent agreement with G3MP2B3 ab initio methods. ${ }^{68}$ Several transition states involving Gly, Gly', Ala and Ala with ${ }^{\circ} \mathrm{OH}$ and $\mathrm{H}_{2} \mathrm{O}_{2}$ were computed in this study. The ability of the MPWKCIS1K and BHandHLYP functionals to reproduce the activation energies computed with the with the G3MP2B3 method was compared by using the $6-311+G(d, p)$ and 6-311+ $+\mathrm{G}(3 \mathrm{df}, 2 \mathrm{p})$ basis sets. The results of this comparison are discussed in Section 3.1. The use of the SCRF with these functionals should yield acceptable results in the systems studied herein. The relative energy values of the structures will be discussed throughout, whereas the 
temperature dependent parameters, $\Delta \mathrm{G}^{\circ}, \Delta \mathrm{H}^{\circ}$ and $\Delta \mathrm{S}^{\circ}$ will be presented for comparison. This will enable the temperature-independent results obtained herein to be compared to larger systems, with more degrees of freedom.

\subsection{Computing the Unfolding of the Pentapeptides}

The Gaussian 09 program package was used to optimize the $N$-Ac-GGGGG-NH $\mathrm{H}_{2}$ (G5) and $\mathrm{N}$-Ac-AAAAA- $\mathrm{NH}_{2}$ (A5) geometries. The G5 and A5 structures were optimized in the gas phase and in an implicit solvent using the unrestricted B3LYP density functional method, with the $6-31 G(d)$ and $6-311+G(d, p)$ basis sets. ${ }^{56-58}$ The implicit solvent was represented by a conductor-like polarizable continuum model (C-PCM) for water, with a dielectric constant $(\varepsilon)$ of 78.39. ${ }^{69}$ The fully-extended conformations ( $\left(\mathrm{G} 5_{\mathrm{EXT}}, \mathrm{A} 5_{\mathrm{EXT}}\right)$ were formed using initial $\phi$ and $\psi$ angles of $180^{\circ}$, whereas the helical conformations $\left(\mathrm{G} 5_{\mathrm{HEL}}, \mathrm{A} 5_{\mathrm{HEL}}\right)$ were stabilized by hydrogen bonds between the respective amide hydrogen and carbonyl oxygen of residues "i" and " $\mathrm{i}+2$ ". The geometry of both structures was subsequently optimized and their frequencies were computed to confirm that they were minima. Figure 5 illustrates the definition of the $\phi, \psi$ and "i" symbols used to specify the sequence number of the amino acid residues in the peptides. The thermodynamic functions were calculated using the unscaled frequencies. A hydrogen atom was removed from the $\mathrm{C}_{\alpha}$ and amide nitrogen of $\mathrm{Gly}^{3}$ and $\mathrm{Ala}^{3}$ in $\mathrm{G} 5$ and $\mathrm{A} 5$ to construct the $\mathrm{G} 5\left(\mathrm{C}_{\alpha}{ }^{\circ}\right), \mathrm{A} 5\left(\mathrm{C}_{\alpha}{ }^{\circ}\right), \mathrm{G} 5\left(\mathrm{~N}^{\circ}\right), \mathrm{A} 5\left(\mathrm{~N}^{*}\right)$ peptide radicals, whereas a hydrogen atom was also removed from the methyl group of $\mathrm{Ala}^{3}$ to form the $\mathrm{A} 5\left(\mathrm{CH}_{2}{ }^{\circ}\right)$ peptide radical. The geometries of the peptide radicals were subsequently optimized in the doublet electron configuration using the levels of theory, conformations and environments used to 
optimize G5 and A5. The bond lengths, $\phi$ and $\psi$ dihedral angles pertaining to $\mathrm{Gly}^{3}$ and $\mathrm{Ala}^{3}$, hydrogen bond distances and root-mean-squared deviations<smiles>C[C@H](NC(=O)[C@H](C)NC(=O)[C@H](C)NC(=O)O)C(=O)O</smiles><smiles>CC(=O)NC(C)(C)C(=O)N[C@@H](C)C(=O)NC(C)(C)C(=O)N[C@@H](C)C(=O)N[C@@H](C)C(N)=O</smiles>

Figure 5. Representations of the $\phi$ and $\psi$ nomenclature for the peptide dihedral angles (top) and the " $\mathrm{i}-$ 1", "i", and " $\mathrm{i}+1$ " nomenclature of amino acid residues of A5 ( $N$-Ac-AAAAA- $\left.\mathrm{NH}_{2}\right)$. The same nomenclature was used for the G5 peptide ( $N$-Ac-GGGGG-NH $\mathrm{NH}_{2}$ ).

(RMSD) of peptide backbone atoms of the peptide radicals were compared to those of the respective G5 and A5 peptides. A diagram that schematically outlines these peptides can be

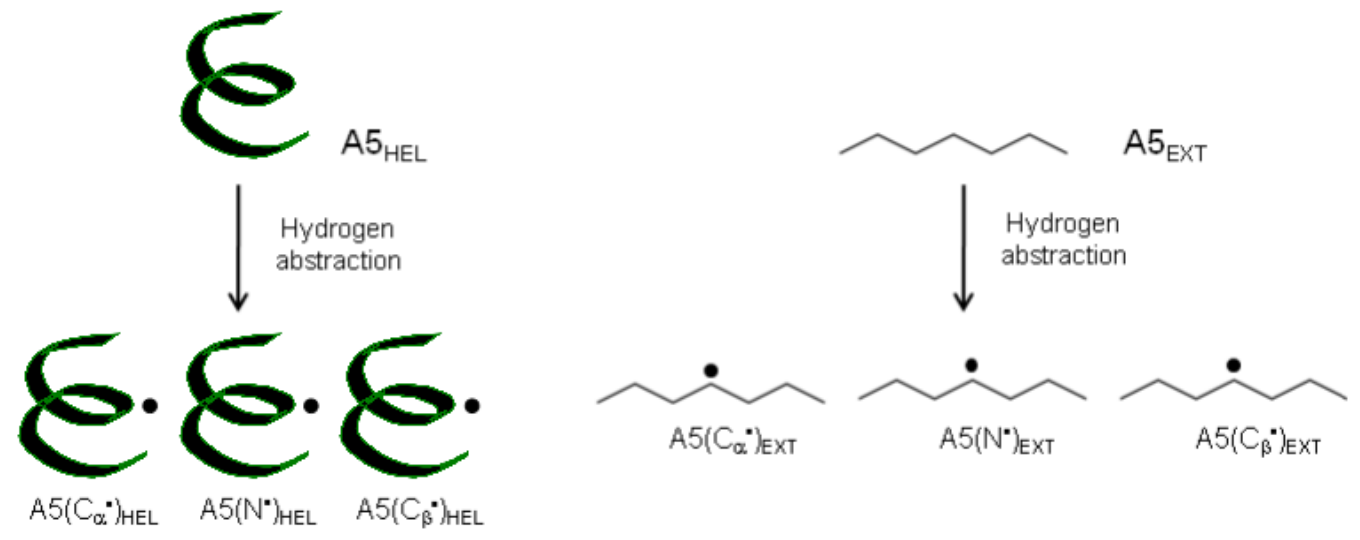

Figure 6. A schematic representation of the peptides computed in this study. The structures of the $\mathrm{A} 5_{\mathrm{HEL}}$ and $\mathrm{A} 5_{\mathrm{EXT}}$ peptides are to be compared to the structures of the respective peptide radicals after hydrogen abstraction. The G5, $\mathrm{G}_{\mathrm{EXT}}$ and $\mathrm{G}_{\mathrm{HEL}}$ peptides were compared in a similar way. 
found in Figure 6.

The $\Delta \mathrm{H}^{\circ}, \Delta \mathrm{G}^{\circ}$ and $\Delta \mathrm{S}^{\circ}$ for the reactions with ${ }^{\circ} \mathrm{OH}, \mathrm{HO}_{2}{ }^{\circ}$ and $\mathrm{O}_{2}^{-\bullet}$ that resulted in the formation of the peptide radicals were measured using the previously described gas phase and implicit solvent conditions. The relative stability and the $\Delta \mathrm{H}^{\circ}, \Delta \mathrm{G}^{\circ}$ and $\Delta \mathrm{S}^{\circ}$ of the unfolding of the peptide radicals were also computed in these conditions.

\subsection{Parameterization of the Gly ${ }^{\circ}$ and Ala ${ }^{\bullet}$ force-fields}

\subsubsection{Force-field Parameterization of Gly}

The parameter fitting of Gly was accomplished by calculating the OPLS-AA/L energy and the analytical energy first derivatives with respect to the molecular mechanical parameters. The point-charge parameters for $\mathrm{N}$-Ac-Gly $-\mathrm{N}$-Me-amide were fitted to the electrostatic potential using the restrained electrostatic potential (RESP) methodology and the RESP program from the AMBER 8 program package. ${ }^{70-73}$ The partial charges on the $N$-Acetyl and $N$-Methyl groups were kept the same as they were in the original OPLS-AA/L force field, to conserve the electroneutrality of the core Gly radical structure. The electrostatic potentials at nine geometries, with independent $\pm 15.0^{\circ}$ fluctuations of $\varphi$ and $\psi$ from the planar equilibrium geometry, were calculated.

\subsubsection{Force-field Parameterization of Ala}

A new atom type was defined for the carbon atom at the radical center (CRA), being different from that at the glycyl radical in order to allow more flexible parameter derivation. However, the van der Waals parameters were chosen to be identical for both of them. The atomic partial charges were generated from RESP HF/6-31G(d) calculation, as in the case of 
Gly. ${ }^{60}$

During parameterization only small perturbations were allowed for all but the torsion internal coordinates. Only the C-N-CRA-CT, H-N-CRA-CT, N-C-CRA-CT, O-C-CRA-CT, N-CRA-CT-H and the C-CRA-CT-H torsion parameters were developed. Rigid rotor approach was used to scan the torsion potential energy surface. The N-CRA-C-O, N-CRA-CN, C-N-CRA-C, H-N-CRA-C, CT1-C-N-CRA, O-C-N-CRA, H-N-C-CRA and CT1-N-CCRA torsion parameters were adopted from the glycyl radical force field.

The proper torsion parameters were derived from LMP2/cc-pVTZ(-f) computations as proposed by Kaminski et al. using a rigid rotor approach from the MP2/6-31+G(d,p) equilibrium geometry. ${ }^{36}$ All the other force field parameters were obtained with the use of $\mathrm{MP} 2 / 6-31+\mathrm{G}(\mathrm{d}, \mathrm{p})$ calculations.

The geometry of $N$-Ac-Ala-NHMe was fully optimized at the MP2/6-31+G(d,p) level of theory. In order to derive the parameters, the potential energy of a series of geometries of $N$-Ac-Ala-NHMe was computed and the variations thereof are shown in Table $\mathbf{1}$.

Table 1. The variation in bond lengths, bond angles and torsional angles used to parameterize the N- $N$-Ac-Ala'Me amide.

\begin{tabular}{ccc}
\hline Parameter & Atoms & Variations \\
\hline Bond Lengths & C-CR & $+/-\left(0.01^{\circ}, 0.02^{\circ}, 0.03^{\circ}, 0.04^{\circ}, 0.05^{\circ}, 0.06^{\circ}, 0.07^{\circ}, 0.08^{\circ}, 0.1^{\circ}, 0.12^{\circ}\right.$, \\
& CR-CT & $\left.0.15^{\circ}\right)$ \\
Bond Angles & CR-N & \\
& CR-CT-H & $+/-\left(1.0^{\circ}, 2.0^{\circ}, 3.0^{\circ}, 4.0^{\circ}, 5.0^{\circ}, 6.0^{\circ}, 7.0^{\circ}, 8.0^{\circ}, 9.0^{\circ}, 10.0^{\circ}, 12.0^{\circ}, 14.0^{\circ}\right.$, \\
& C-CR-CT & $\left.16.0^{\circ}, 20.0^{\circ}\right)$ \\
Torsional Angles & N-C-CT & $15.0^{\circ}$ increments \\
& T1 & \\
& T2 & \\
& T3 & \\
\hline
\end{tabular}

Quantum chemical calculations were performed with the Gaussian09 software package, while the parameter fitting was carried out by Professor István Komáromi, at the University of Debrecen. ${ }^{74}$ 


\subsection{Molecular Dynamics Simulations of the Ala Heptapeptides}

Using the newly developed alanyl radical parameters described in Section 2.1, the conformational space of two heptapeptides was investigated with molecular dynamics simulations. The peptides were solvated with 2360 TIP4P water molecules in a cubic box of $41.7 \AA \times 41.7 \AA \times 41.7 \AA .^{75}$ The two model heptaalanyl peptides were used: $N$-Ac 1 -Ala ${ }_{2}-$ $\mathrm{Ala}_{3}-\mathrm{Ala}_{4}-\mathrm{Ala}_{5}-\mathrm{Ala}_{6}-\mathrm{Ala}_{7}-\mathrm{Ala}_{8}-\mathrm{Nma}_{9}(\mathrm{ALA})$ and $N-\mathrm{Ac}_{1}-\mathrm{Ala}_{2}-\mathrm{Ala}_{3}-\mathrm{Ala}_{4}-\mathrm{Alr}_{5}-\mathrm{Ala}_{6}-\mathrm{Ala}_{7}-\mathrm{Ala}_{8}-$ $\mathrm{Nma}_{9}$ (ALR), where the central alanine $\left(\mathrm{Ala}_{5}\right)$ of the latter peptide was modified manually into the radical form $\left(\mathrm{Alr}_{5}\right)$ by deleting the hydrogen from the $\mathrm{C}_{\alpha}$ atom (Figure 7).
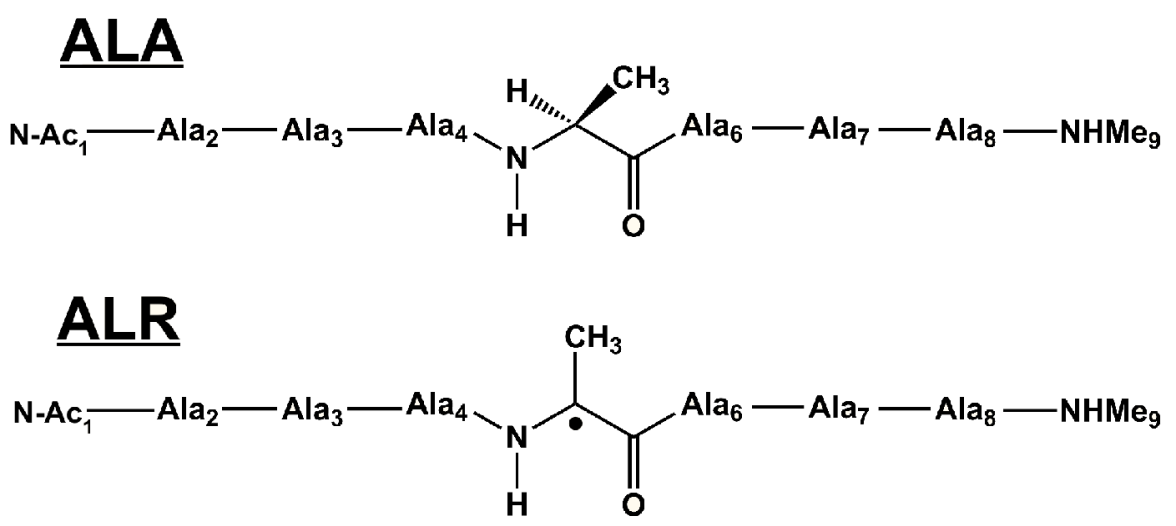

Figure 7. A schematic representation of the ALA and ALR heptapeptides. The force field for the ALR peptide contains the newly-developed alanyl radical parameters.

The system was pre-equilibrated with the provided protocol followed by a 96 ns simulation under NPT conditions $(\mathrm{T}=310 \mathrm{~K}, \mathrm{P}=1.01325$ bar), using the Martyna-TobiasKlein pressure and temperature control. ${ }^{76}$ A 2 fs integration step was used, while the cutoff for the short-range non-bonded interactions was $9 \AA$ and was updated every second step. Long-range electrostatic interactions were treated with the particle mesh Ewald method, containing 32 Fourier mesh points along each axis, and were updated every third integration 
step. $^{77}$ The structures were saved every $4.8 \mathrm{ps}$, which established a trajectory of 20,000 structures.

Table 2. Definitions of the Secondary Structure Elements (SSE). Higher order structures consist of repeating turn structures.

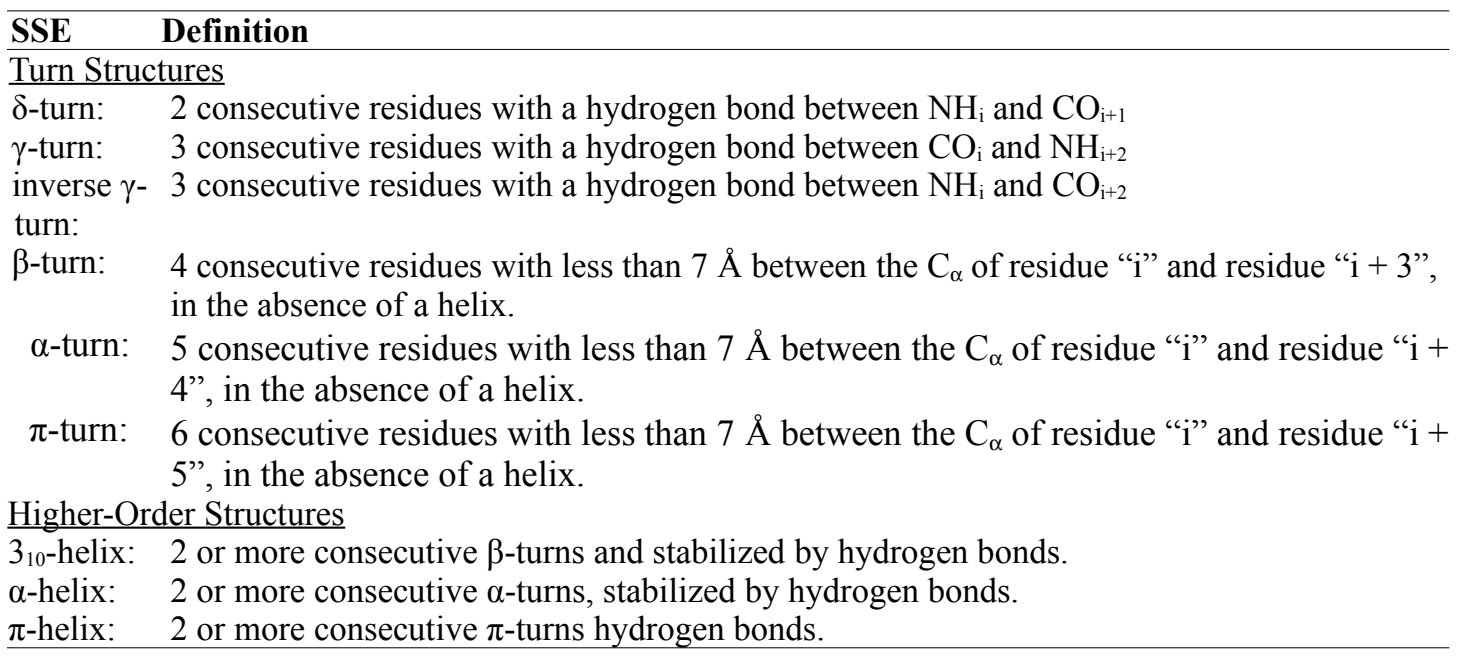

The density Ramachandran map was used to analyze the conformational space sampled by the $\mathrm{Ala}_{5}$ or $\mathrm{Alr}_{5}$ residues. The Ramachandran space was divided into $30^{\circ} \times 30^{\circ}$ boxes, and the percentage of the structures in which $\mathrm{Ala}_{5}$ or $\mathrm{Alr}_{5}$ had $\phi$ and $\psi$ angles values that fit within each box was recorded. The number of secondary structure elements that were found in the discrete regions of the heptapeptides containing the $\mathrm{Ala}_{5}$ or $\mathrm{Alr}_{5}$ residues was quantified using secondary structure analysis (Table 2 ).

The secondary structure elements consisted of individual $\beta-, \gamma-\delta$-, $\alpha-$, and $\pi$-turns as described by Chou, and also higher-order secondary structure elements (SSE), which are composed of individual turns that combine to form helices. ${ }^{78}$ The definition of the each secondary structure element can be found in Table 2 .

An $\mathrm{H}$ bond was assigned to the peptide residues if the distance between the amide $\mathrm{N}$ and the carbonyl oxygen was less than $3.5 \AA$ and the angle, $\alpha(\mathrm{N}-\mathrm{H} \cdots \mathrm{O})$, was greater than $100^{\circ}$. 


\subsection{RESULTS}

\subsection{General Features of the Amino Acid Potential Energy Surfaces}

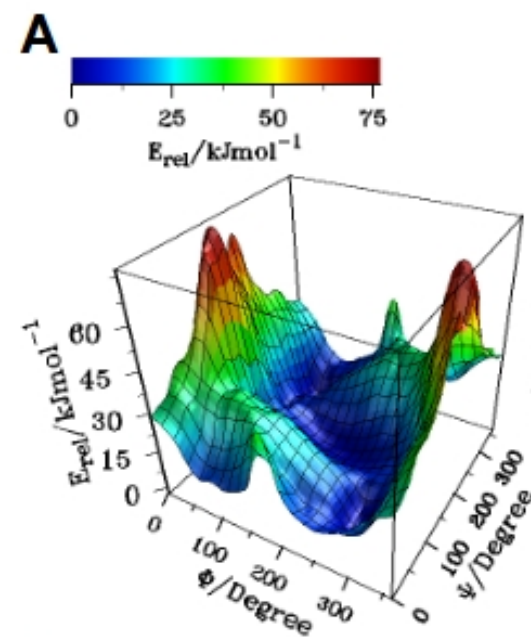

B
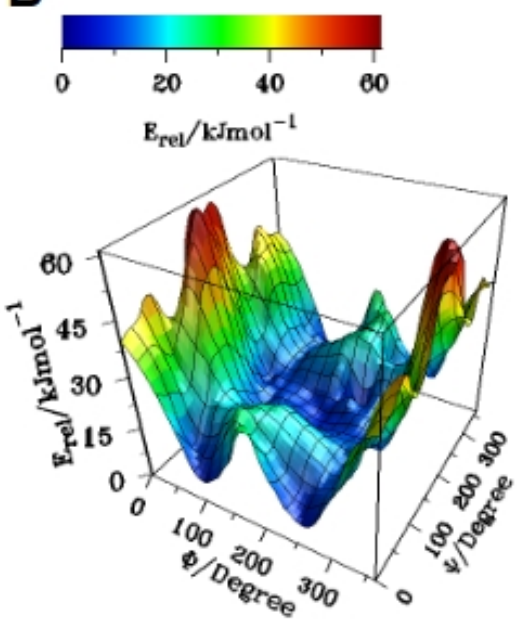
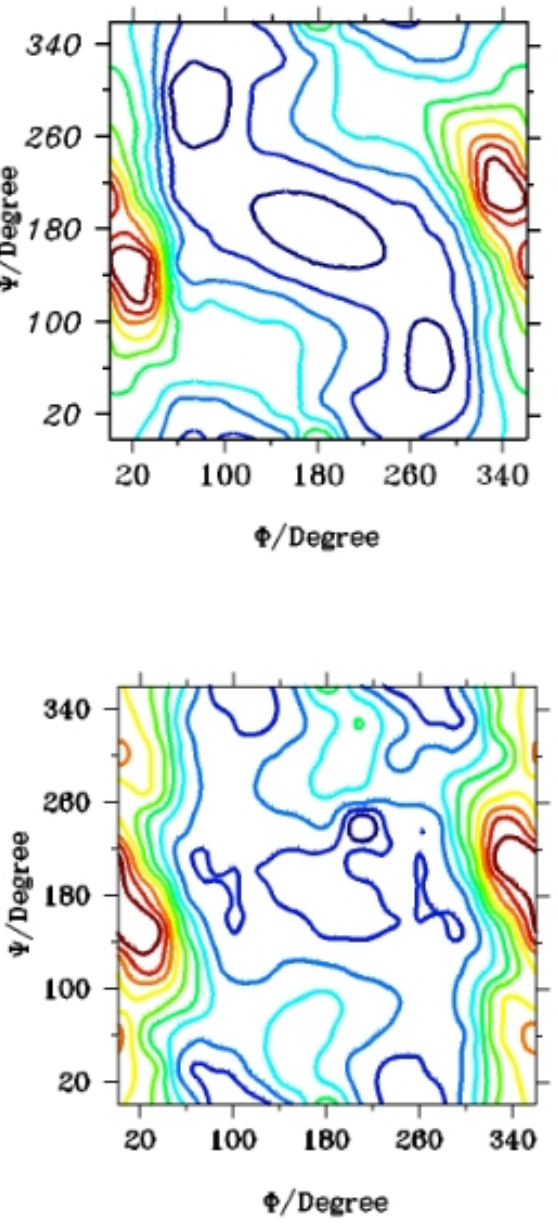

Figure 8. PES and contour plot for N-Ac-Gly-NHMe in the gas phase (A) and in solution (B).

The PES of $\mathrm{N}$-Ac-Gly-NHMe in the gas phase was predominantly flat, except for a maximum at $\phi=0^{\circ}$ and $\psi=180^{\circ}$ (Figure 8A). A large and broad valley connected several conformations of Gly. When $\phi$ was between $30^{\circ}$ and $120^{\circ}$ and $\psi$ between $150^{\circ}$ and $300^{\circ}$, the system was in a low energy state. This was also the case when $\phi$ was between $90^{\circ}$ and $270^{\circ}$ and $\psi$ was between $150^{\circ}$ and $210^{\circ}$, and when $\phi$ was between $270^{\circ}$ and $300^{\circ}$ and $\psi$ was 
between $30^{\circ}$ and $\psi 180^{\circ}$. These three regions were connected and contained low-energy conformers with minima located in the $\gamma_{D}, \beta_{\mathrm{L}}$ and $\gamma_{\mathrm{L}}$ conformations. The PES of $N$-Ac-GlyNHMe in a simulated aqueous environment (Figure 8B) was similar to that of the gas phase PES, indicating the same stable conformations as that of the gas phase model (Figure 8A).

The $\mathrm{C}_{\alpha}$-centered $\mathrm{N}$-Ac-Gly-NHMe lacked the conformational flexibility of the closedshell model. The PES of this model indicated that the $\beta_{\mathrm{L}}$ conformation was the global minimum (Figure 9A).

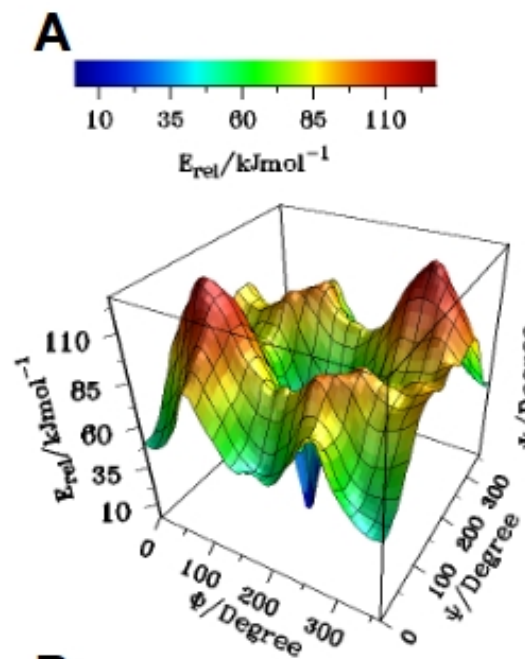

B

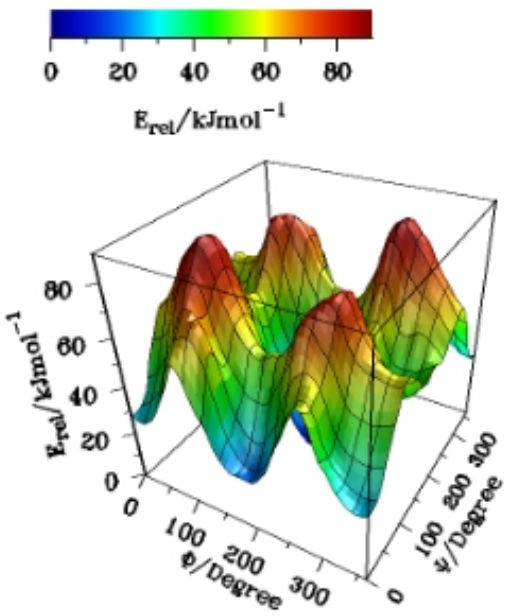

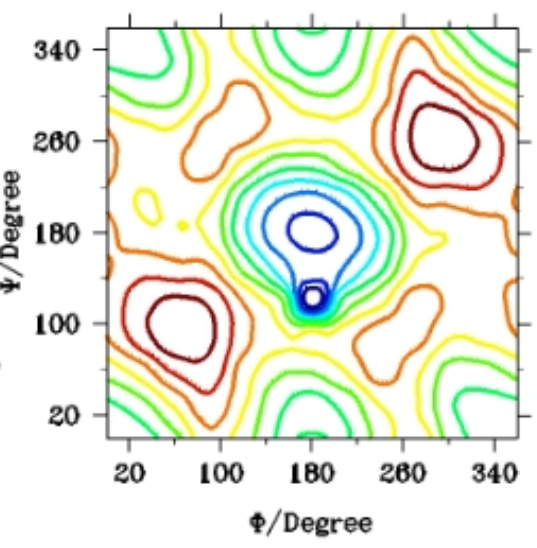

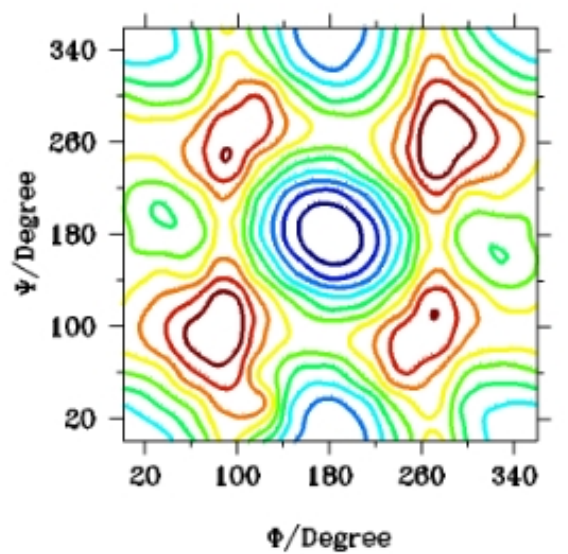

Figure 9. PES and contour plot for $N$-Ac-Gly-NHMe in the gas phase (A) and in solution (B). 
This minimum had a high energy barrier of about $80 \mathrm{~kJ} \mathrm{~mol}^{-1}$ extending in a $90^{\circ}$ radius from the geometry with $\phi$ of $180^{\circ}, \psi$ of $180^{\circ}$. Other minima were present in the $\delta_{\mathrm{L}}, \delta_{\mathrm{D}}$, and $\phi=0^{\circ}$, $\psi=0^{\circ}$ geometry, which also includes the $\alpha_{D}, \alpha_{L}, \gamma_{D}, \gamma_{L}$ conformations. Two maxima were located at $\phi=60^{\circ}, \psi=90^{\circ}$ and $\phi=300^{\circ}, \psi=270^{\circ}$, and were $127 \mathrm{~kJ} \mathrm{~mol}^{-1}$ less stable than the global minimum. The aqueous environment induced a qualitatively similar PES (Figure 3B) to that in the gas phase. The global minimum was still present in the $\beta_{\mathrm{L}}$ conformation with a barrier of $60 \mathrm{~kJ} \mathrm{~mol}^{-1}$, restricting this conformation. The minima found in the gas phase also were found in the solvent. In addition, the solvent stabilized $\varepsilon_{\mathrm{D}}$ and $\varepsilon_{\mathrm{L}}$ conformations. The unstable conformers in the aqueous environment had the same geometry as those in the gas phase, but the structures were $88 \mathrm{~kJ} \mathrm{~mol}^{-1}$ less stable than the global minimum.

\subsubsection{Comparison of the MPWKCIS1K and BHandHLYP functionals}

Activation energies of Gly- ${ }^{\cdot} \mathrm{OH}$, Ala- ${ }^{\cdot} \mathrm{OH}$, Gly $-\mathrm{H}_{2} \mathrm{O}_{2}$ and Ala $-\mathrm{H}_{2} \mathrm{O}_{2}$ transition states using the BHandHLYP/6-311+G(d,p), BHandHLYP/6-311++G(3df,2p), MPWKCIS1K/6$311+\mathrm{G}(\mathrm{d}, \mathrm{p})$, MPWKCIS1K/6-311++G(3df,2p) methods were calculated on geometries obtained by the BHandHLYP/6-311+G(d,p) level of theory. This was done to compare the accuracy of the respective method. The G3MP2/BHandHLYP/6-311G(d,p) calculations were

used as a reference and the results of the comparison are shown in Table $3 .^{38,68}$ The maximum absolute deviation (MAD) and average absolute deviation (AAD) of the BhandHLYP/6$311+\mathrm{G}(\mathrm{d}, \mathrm{p})$ energies from the reference values is 19.4 and $14.5 \mathrm{~kJ} \mathrm{~mol}^{-1}$, respectively, showing that the use of this functional with the smaller basis set is unsuitable for computing 
Table 3. Single point activation energies of Gly- ${ }^{-} \mathrm{OH}$, Ala- ${ }^{-} \mathrm{OH}, \mathrm{Gly}^{*}-\mathrm{H}_{2} \mathrm{O}_{2}$ and $\mathrm{Ala} \cdot \mathrm{H}_{2}-\mathrm{O}_{2}$ calculated with the BHandHLYP and MPWKCIS1K functionals. The G3MP2 method was used as a reference. The maximum absolute deviation (MAD) and average absolute deviation (AAD) are reported, and the deviations pertaining to the Gly- ${ }^{\circ} \mathrm{OH}$ and Ala- $\mathrm{OH}$ transition states are in parenthesis.

\begin{tabular}{|c|c|c|c|c|c|c|}
\hline \multirow{2}{*}{$\begin{array}{l}\text { Transition } \\
\text { State }\end{array}$} & \multirow{2}{*}{ Conf } & \multicolumn{5}{|c|}{ Activation Energy $\left(\Delta \mathbf{E}^{0}\right) / \mathrm{kJ} \mathrm{mol}^{-1}$} \\
\hline & & $\begin{array}{c}\text { BHandHLYP/ } \\
\text { 6-311+G(d,p) }\end{array}$ & $\begin{array}{c}\text { BHandHLYP/ } \\
\text { 6-311++G(3df,2p) }\end{array}$ & G3MP2 & $\begin{array}{l}\text { MPWKCIS1K } \\
/ 6-311+G(d, p)\end{array}$ & $\begin{array}{c}\text { MPWKCIS1K/ } \\
\text { 6-311++G(3df,2p) }\end{array}$ \\
\hline \multirow[t]{5}{*}{ Gly-'OH } & $\beta_{\mathrm{L}}$ & 12.2 & -5.3 & -2.9 & 0.2 & -0.3 \\
\hline & $\gamma_{\mathrm{L}}$ & 18.1 & 0.1 & 2.2 & 4.5 & 3.8 \\
\hline & $\gamma_{\mathrm{D}}$ & 15.1 & -4.2 & 5.7 & 1.0 & 0.3 \\
\hline & $\alpha_{L}$ & 22.2 & 4.2 & 3.4 & 7.9 & 7.0 \\
\hline & $\alpha_{D}$ & 19.9 & 1.1 & 7.5 & 6.6 & 5.6 \\
\hline \multirow[t]{5}{*}{ Ala-'OH } & $\beta_{\mathrm{L}}$ & 11.0 & -6.4 & -6.3 & -1.3 & -1.6 \\
\hline & $\gamma_{\mathrm{L}}$ & 14.0 & -3.7 & -3.1 & 2.1 & 1.6 \\
\hline & $\gamma_{D}$ & 19.1 & 0.4 & 0.6 & 3.8 & 2.9 \\
\hline & $\alpha_{L}$ & 15.2 & -3.0 & -4.2 & 2.7 & 1.8 \\
\hline & $\alpha_{\mathrm{D}}$ & 20.4 & 2.4 & 5.9 & 9.6 & 8.6 \\
\hline Gly $-\mathrm{H}_{2} \mathrm{O}_{2}$ & $\beta_{\mathrm{L}}$ & 57.3 & 51.8 & 44.9 & 45.8 & 51.2 \\
\hline $\mathrm{Ala}-\mathrm{H}_{2} \mathrm{O}_{2}$ & $\beta_{\mathrm{L}}$ & 35.1 & 47.6 & 31.9 & 41.4 & 47.8 \\
\hline MAD & & $19.4(19.4)$ & $15.7(9.9)$ & $0.0(0.0)$ & $9.5(6.9)$ & $15.9(6.0)$ \\
\hline AAD & & $14.5(15.8)$ & $4.2(2.7)$ & $0.0(0.0)$ & $4.2(4.0)$ & $4.8(3.6)$ \\
\hline
\end{tabular}

transition state energies, given the overestimation of the activation energies. The use of the BHandHLYP/6-311++G(3df,2p) $\left(\mathrm{MAD}=15.7 \mathrm{~kJ} \mathrm{~mol}^{-1}, \quad \mathrm{AAD}=4.2 \mathrm{~kJ} \mathrm{~mol}^{-}\right.$ $\left.{ }^{1}\right), \operatorname{MPWKCIS} 1 \mathrm{~K} / 6-311+\mathrm{G}(\mathrm{d}, \mathrm{p}) \quad\left(\mathrm{MAD}=9.5 \mathrm{~kJ} \mathrm{~mol}^{-1}, \mathrm{AAD}=4.2 \mathrm{~kJ} \mathrm{~mol}^{-1}\right)$ and MPWKCIS1K/6-311++G(3df,2p) $\left(\mathrm{MAD}=15.9 \mathrm{~kJ} \mathrm{~mol}^{-1}, \mathrm{AAD}=6.0 \mathrm{~kJ} \mathrm{~mol}^{-1}\right)$ functionals yielded results that are close to the experimental error, given that the AAD values are $6.0 \mathrm{~kJ}$ $\mathrm{mol}^{-1}$ or less.

The use of either basis set with the MPWKCIS1K functional and the larger basis set with the BHandHLYP functional is suitable for these systems. When the reactions involving $\mathrm{OH}$ are combined with that of $\mathrm{H}_{2} \mathrm{O}_{2}$ to regenerate Gly or Ala, the Gly- ${ }^{\circ} \mathrm{OH}$ and Ala- $\mathrm{OH}$ transition 
states were shown to be the rate limiting step. Therefore, the accuracy of the Gly- ${ }^{\circ} \mathrm{OH}$ and Ala- ${ }^{\circ} \mathrm{OH}$ barrier height energies are crucial for determining the minimum energy path for the 'OH-initiated unfolding of Gly and Ala. When the conformers of the Gly- $\mathrm{OH}$ and Ala- $\mathrm{OH}$ transition states are considered, the MAD and AAD obtained from the MPWKCIS1K/6-311+ $+\mathrm{G}(3 \mathrm{df}, 2 \mathrm{p})$ combine to be the lowest of the three methods $\left(\mathrm{MAD}=6.0 \mathrm{~kJ} \mathrm{~mol}^{-1}, \mathrm{AAD}=3.6\right.$ $\mathrm{kJ} \mathrm{mol}^{-1}$ ), therefore this method was chosen for the remainder of the calculations. The efficiency of this computational method makes it suitable for use in larger systems in future studies.

\subsection{Hydrogen Abstraction from the Monopeptides}

The conformers of the Gly, Gly, Ala and Ala potential energy surfaces were identified from the respective potential energy surface. The pre-reaction complexes, transition states, post-reaction complexes and a general description of the $\mathrm{H}$ abstraction reaction coordinate with ${ }^{\circ} \mathrm{OH}$ are presented in the subsequent sections.

\subsubsection{The Potential Energy Surfaces}

Figure 10 shows the Gly and Ala potential energy surfaces. The subsequent optimization of the minima of the PES of Gly and Ala each yielded five minima: $\beta_{L}, \gamma_{L}, \gamma_{D}$, $\alpha_{\mathrm{L}}$ and $\alpha_{\mathrm{D}}$. The $\beta_{\mathrm{L}}$ conformation is the global minimum in the case of Gly, whereas the $\alpha_{\mathrm{L}}$ conformation is the global minimum of the Ala PES. The $\phi$ and $\psi$ angles and energy values for all of the minima can be found in Table 4. In Ala, the D-configurations are less favorable and are more than $10 \mathrm{~kJ} \mathrm{~mol}^{-1}$ higher in energy than the respective L-configurations. Conversely, the $\alpha_{\mathrm{L}}$ and $\gamma_{\mathrm{L}}$ conformations have energy values that are similar to their 

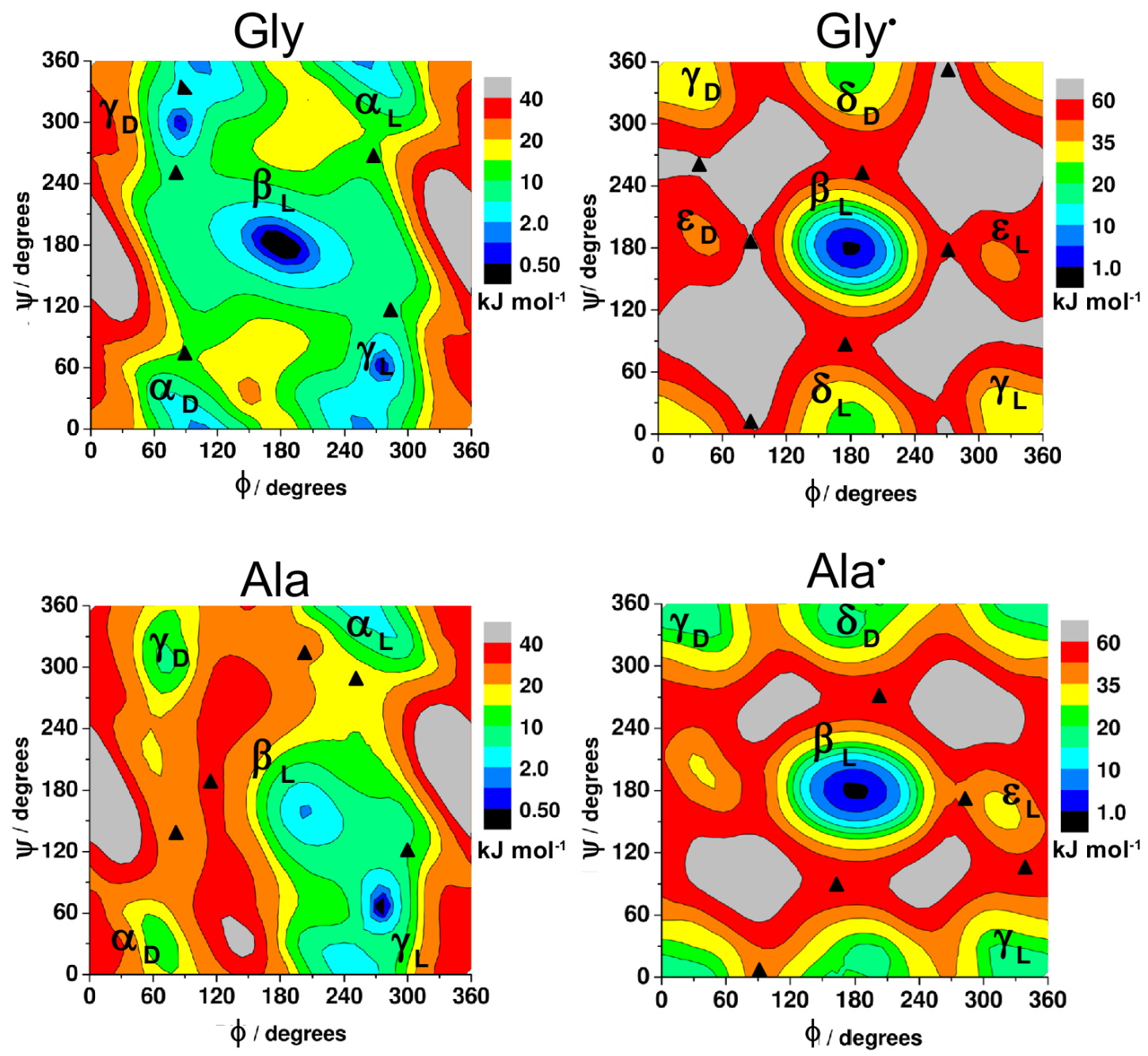

Figure 10. The potential energy surfaces of the Gly, Gly', Ala, and Ala amino acid diamides. The minima are labeled by their respective conformation whereas the transition states are labeled with triangles.

respective $\alpha_{D}$ and $\gamma_{D}$ conformations in Gly.

The $\beta_{\mathrm{L}}$ conformation is the global minimum of both the Ala ${ }^{\bullet}$ and the Gly potential energy surfaces. These conformations have the lowest relative free energy and enthalpy, and also the most entropy. In contrast to the closed-shell Gly and Ala potential energy surfaces, the other minima in the $\mathrm{Gly}^{*}$ and Ala ${ }^{*}$ surfaces are less stable than their respective global minimum. The higher-energy minima of Gly are greater than the global minimum by $20 \mathrm{~kJ}$ 
$\mathrm{mol}^{-1}$, whereas energy of the the Ala ${ }^{\cdot}$ minima are $15 \mathrm{~kJ} \mathrm{~mol}^{-1}$ higher in energy than the global minimum. Moreover, to convert from the global minima of the $\mathrm{Gly}^{\bullet}$ and Ala structures to any of the other minima requires at least $50 \mathrm{~kJ} \mathrm{~mol}^{-1}$ of energy to overcome the $\phi$ and $\psi$ rotational barriers. Therefore, the Gly and Ala peptide radicals are prone to convert to the $\beta_{\mathrm{L}}$ conformer. This increased barrier height can be attributed to the increased electron delocalization and increased influence of the capto-dative effect shown in the $\beta_{\mathrm{L}}$ conformation. This barrier constrains the conformation of the Gly and Ala structures and increases the propensity of these molecules to be in the $\beta$-conformation. The first-order saddle points of the potential energy surfaces listed in Table 4 show the relative flexibility of the Gly Gly', Ala and Ala residues. The difference in energy between the minima and firstorder saddle points of Gly $\left(17 \mathrm{~kJ} \mathrm{~mol}^{-1}\right)$ is less than that of Ala $\left(33 \mathrm{~kJ} \mathrm{~mol}^{-1}\right)$, indicating that Gly is more flexible than Ala. The relative energy of the transition states (first-order saddle points) of the Gly PES is similar to those of Ala and Ala', suggesting that the peptide radicals have a similar flexibility. The $\Delta \mathrm{H}^{\mathrm{o}}$ values corresponded well with the electronic energy values $(\Delta \mathrm{E})$. The $\Delta \mathrm{G}^{\mathrm{o}}$ values were usually more elevated than the $\Delta \mathrm{E}$ values and this increase was usually coupled to an increase in the negativity of the $\Delta S^{o}$ value. The $\Delta S^{o}$ values of the transition states were generally lower than those of the minima, due to the extra intrinsic degree of freedom of the transition state structures.

\subsubsection{The Hydrogen Abstraction Reaction Coordinates}

The structures and relative energies of the different Gly and Ala conformers in complexes with ${ }^{\circ} \mathrm{OH}$ will be presented in the subsequent sections. 
Table 4. Conformation (Conf), $\phi$ and $\psi$ angles, intra-residue hydrogen bond $[(\mathrm{N}) \mathrm{H} \cdots \mathrm{O}(=\mathrm{C})]$ and the $\Delta \mathrm{E}^{\circ}$ rel, $\Delta \mathrm{G}^{\circ}{ }_{\text {rel, }} \Delta \mathrm{H}^{\circ}{ }_{\text {rel, }}, \Delta \mathrm{S}_{\text {rel }}^{\circ}$ of the lowest energy conformations and transition state structures of Gly, Gly', Ala and Ala:

\begin{tabular}{|c|c|c|c|c|c|c|c|}
\hline Struct. & Conf. & $\phi, \psi /$ degrees & $\begin{array}{c}(\mathrm{N}) \mathrm{H} \cdots \mathbf{O}(=\mathrm{C}) \\
/ \AA\end{array}$ & $\underset{\mathbf{k J} \mathbf{~ m o l}^{-1}}{\Delta \mathbf{E}_{\text {rel }}^{\mathbf{0}} /}$ & $\begin{array}{c}\Delta \mathbf{G}^{\mathbf{o}}{ }_{\text {rel }} / \\
\mathbf{k J ~ m o l}^{-1}\end{array}$ & 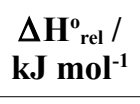 & $\underset{\mathbf{J} \mathbf{m o l}^{-1} \mathbf{K}^{-1}}{\Delta \mathbf{S}^{\mathbf{o}} /} /$ \\
\hline \multirow[t]{5}{*}{ Gly } & $\beta_{\mathrm{L}}$ & $-179.9,179.9$ & 2.18 & 0.0 & 0.0 & 0.0 & 0.0 \\
\hline & $\gamma_{\mathrm{L}}$ & $-83.9,60.4$ & 2.06 & 3.8 & 9.5 & 5.2 & -14.6 \\
\hline & $\gamma_{\mathrm{D}}$ & $83.9,-60.4$ & 2.06 & 3.8 & 9.5 & 5.2 & -14.6 \\
\hline & $\alpha_{\mathrm{L}}$ & $-92.5,-5.8$ & 3.37 & 0.1 & -0.1 & 0.7 & 2.9 \\
\hline & $\alpha_{\mathrm{D}}$ & $92.6,5.6$ & 3.37 & 0.1 & -0.1 & 0.7 & 2.8 \\
\hline \multirow[t]{5}{*}[\text{Gly}]{$^{\ddagger}$} & $\gamma_{D}<->\alpha_{D}$ & $88.0,-6.70$ & 3.19 & 2.8 & 5.4 & -1.1 & -21.8 \\
\hline & $\beta_{\mathrm{L}}<->\gamma_{\mathrm{L}}$ & $-77.4,-115.2$ & 2.78 & 11.5 & 16.8 & 8.1 & -29.3 \\
\hline & $\beta_{\mathrm{L}}<->\gamma_{\mathrm{D}}$ & $77.4,115.2$ & 2.78 & 11.5 & 16.8 & 8.1 & -29.2 \\
\hline & $\beta_{L} \ll->\alpha_{L}$ & $-95.3,-74.2$ & 3.97 & 16.4 & 20.3 & 12.7 & -25.4 \\
\hline & $\beta_{\mathrm{L}}<->\alpha_{\mathrm{D}}$ & $95.2,74.2$ & 3.97 & 16.4 & 20.3 & 12.7 & -25.4 \\
\hline \multirow[t]{7}{*}{ Gly } & $\beta_{\mathrm{L}}$ & $-179.9,-180.0$ & 2.3 & 0.0 & 0.0 & 0.0 & 0.0 \\
\hline & $\gamma_{\mathrm{L}}$ & $-20.4,4.6$ & 1.81 & 31.0 & 31.8 & 31.9 & 0.5 \\
\hline & $\gamma_{\mathrm{D}}$ & $20.2,-4.8$ & 1.81 & 30.9 & 32.5 & 31.9 & -2.0 \\
\hline & $\delta_{\mathrm{L}}$ & $-172.8,12.4$ & 3.87 & 39.3 & 40.3 & 38.4 & -6.3 \\
\hline & $\delta_{\mathrm{D}}$ & $172.8,-12.4$ & 3.87 & 21.0 & 23.9 & 21.0 & -9.7 \\
\hline & $\varepsilon_{\mathrm{L}}$ & $-47.2,165.9$ & 3.73 & 39.3 & 40.3 & 38.4 & -6.3 \\
\hline & $\varepsilon_{\mathrm{D}}$ & $47.2,-165.9$ & 3.73 & 39.3 & 40.3 & 38.4 & -6.3 \\
\hline \multirow[t]{7}{*}{ [Gly']" } & $\gamma_{\mathrm{L}}<->\delta_{\mathrm{D}}$ & $10.7,-94.1$ & 3.07 & 61.8 & 63.9 & 57.0 & -23.1 \\
\hline & $\delta_{\mathrm{L}}<->\gamma_{\mathrm{D}}$ & $-95.5,-2.2$ & 3.35 & 57.2 & 53.2 & 50.2 & -10.0 \\
\hline & $\delta_{\mathrm{D}}<->\gamma_{\mathrm{L}}$ & $95.5,2.2$ & 3.35 & 57.2 & 53.2 & 50.2 & -10.1 \\
\hline & $\beta_{\mathrm{L}} \ll->\delta_{\mathrm{L}}$ & $165.1,97.5$ & 3.21 & 54.2 & 54.7 & 49.4 & -17.9 \\
\hline & $\beta_{\mathrm{L}}<->\delta_{\mathrm{D}}$ & $-165.2,-97.5$ & 3.21 & 54.2 & 54.7 & 49.4 & -17.8 \\
\hline & $\beta_{\mathrm{L}} \ll->\varepsilon_{\mathrm{L}}$ & $-86.0,178.4$ & 3.16 & 59.1 & 55.7 & 52.3 & -11.2 \\
\hline & $\beta_{\mathrm{L}}<->\varepsilon_{\mathrm{D}}$ & $86.0,-178.4$ & 3.16 & 59.1 & 55.7 & 52.3 & -11.2 \\
\hline
\end{tabular}


Table 4. Continued

\begin{tabular}{|c|c|c|c|c|c|c|c|}
\hline Struct. & Conf. & $\phi, \psi /$ degrees & $\begin{array}{c}(\mathbf{N}) \mathbf{H}^{\cdots \cdots} \mathbf{O}(=\mathbf{C}) \\
/ \AA\end{array}$ & $\underset{\mathbf{k J} \mathbf{~ m o l}^{-1}}{\Delta \mathbf{E}_{\text {rel }}^{\text {o }} /}$ & $\begin{array}{c}\Delta \mathbf{G}_{\text {rel }}^{\mathbf{0}} / \\
\mathbf{k J} \mathbf{m o l}^{-1}\end{array}$ & $\begin{array}{c}\Delta \mathbf{H}_{\text {rel }}^{\mathbf{o}} / \\
\mathbf{k J} \mathbf{~ m o l}^{-1}\end{array}$ & $\begin{array}{c}\Delta \mathbf{S}_{\text {rel }}^{\mathbf{o}} / \\
\mathbf{J} \mathbf{m o l}^{-1} \mathbf{K}^{-1}\end{array}$ \\
\hline \multirow[t]{5}{*}{ Ala } & $\beta_{\mathrm{L}}$ & $-154.3,156.7$ & 2.23 & 0.0 & 0.0 & 0.0 & 0.0 \\
\hline & $\gamma_{\mathrm{L}}$ & $-85.8,70.5$ & 2.09 & 1.3 & 4.0 & 1.8 & -7.3 \\
\hline & $\gamma_{\mathrm{D}}$ & $74.4,-52.6$ & 1.93 & 10.5 & 16.3 & 11.7 & -15.4 \\
\hline & $\alpha_{\mathrm{L}}$ & $-83.0,-17.6$ & 3.36 & -0.7 & 0.4 & -0.3 & -2.4 \\
\hline & $\alpha_{D}$ & $63.7,34.1$ & 3.21 & 9.6 & 12.3 & 9.7 & -8.8 \\
\hline \multirow[t]{5}{*}[\text{Ala}]{$^{*}$} & $\beta_{\mathrm{L}} \ll->\alpha_{\mathrm{L}}$ & $-96.7,-75.3$ & 3.92 & 15.8 & 16.0 & 10.4 & -18.7 \\
\hline & $\beta_{\mathrm{L}} \ll->\gamma_{\mathrm{L}}$ & $-76.4,117.6$ & 2.88 & 7.5 & 8.6 & 2.4 & -20.8 \\
\hline & $\alpha_{D}<->\gamma_{D}$ & $81.5,155.4$ & 3.24 & 25.5 & 28.2 & 26.0 & -21.5 \\
\hline & $\beta_{L}<->\gamma_{D}$ & $117.4,-150.4$ & 2.32 & 33.5 & 36.7 & 29.0 & -25.7 \\
\hline & $\alpha_{L} \ll \gamma_{D}$ & $-157.6,-61.1$ & 3.50 & 19.6 & 20.5 & 14.1 & -21.5 \\
\hline \multirow[t]{5}{*}{ Ala ${ }^{\circ}$} & $\beta_{\mathrm{L}}$ & $-171.9,176.8$ & 2.09 & 0.0 & 0.0 & 0.0 & 0.0 \\
\hline & $\gamma_{\mathrm{L}}$ & $-46.7,10.8$ & 1.85 & 18.3 & 22.0 & 18.0 & -13.5 \\
\hline & $\gamma_{\mathrm{D}}$ & $46.7,-10.7$ & 1.85 & 18.3 & 22.0 & 18.0 & -13.6 \\
\hline & $\varepsilon_{\mathrm{L}}$ & $-48.8,159.5$ & 4.28 & 24.0 & 26.8 & 22.8 & -13.4 \\
\hline & $\delta_{\mathrm{D}}$ & $155.5,-15.0$ & 3.75 & 15.5 & 20.7 & 15.3 & -18.2 \\
\hline \multirow[t]{5}{*}[\mathrm{Ala}^{*}]{$^{\ddagger}$} & $\beta_{\mathrm{L}}<->\delta_{\mathrm{L}}$ & $-13.5,96.1$ & 3.03 & 45.5 & 48.5 & 39.8 & -29.2 \\
\hline & $\beta_{\mathrm{L}}<->\delta_{\mathrm{L}}$ & $95.7,2.6$ & 3.32 & 30.8 & 28.9 & 23.1 & -19.7 \\
\hline & $\beta_{\mathrm{L}}<->\delta_{\mathrm{L}}$ & $-84.3,172.7$ & 3.04 & 40.2 & 37.4 & 32.7 & -15.6 \\
\hline & $\beta_{\mathrm{L}}<->\delta_{\mathrm{L}}$ & $-177.3,99.9$ & 2.95 & 53.2 & 54.1 & 47.8 & -21.4 \\
\hline & $\beta_{L} \ll->\delta_{L}$ & $177.3,-99.9$ & 2.95 & 53.2 & 54.1 & 47.8 & -21.4 \\
\hline
\end{tabular}

\subsubsection{Pre-Reaction van der Waals complexes}

In each Gly van der Waals complex, the hydrogen atom of the ${ }^{\circ} \mathrm{OH}$ radical formed a hydrogen bond with a carbonyl oxygen that was between $1.73 \AA$ and $1.80 \AA$ (Table 4). The structures of the van der Waals complexes are shown in Figure 11. In the $\gamma_{D}$ and $\alpha_{D}$ conformations, the hydrogen atom formed a hydrogen bond with the carbonyl residue of the $\mathrm{i}^{\text {th }}$ residue, whereas the oxygen atom of the ${ }^{\circ} \mathrm{OH}$ radical was equidistant to the both the pro- $\mathrm{L}$ and pro-D hydrogen atoms. This was also true in the $\beta_{\mathrm{L}}$ conformation, however the hydroxyl 
Table 5. The distances between the Gly and Ala diamide and the ${ }^{\circ} \mathrm{OH}$ radical along the reaction coordinate. The $\mathrm{C} \cdots \mathrm{H}(-\mathrm{O})$ bond is between the $\mathrm{C}_{\alpha}$ and the hydrogen (to be abstracted); the $(\mathrm{C}-) \mathrm{H} \cdots \mathrm{O}$ bond is between the abstracted hydrogen and the oxygen of the hydroxy group and the $\mathrm{H} \cdots \mathrm{O}(=\mathrm{C})$ bond is between the hydroxy oxygen and the carbonyl carbon of the amino acid diamide.

\begin{tabular}{|c|c|c|c|c|}
\hline \multirow[t]{2}{*}{ Struct. } & \multirow[t]{2}{*}{ Conf. } & \multicolumn{3}{|c|}{ Distances / Å } \\
\hline & & 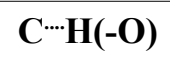 & $(\mathrm{C}-) \mathrm{H} \cdots \mathrm{O}$ & $\mathbf{H} \cdots \mathbf{O}(=\mathbf{C})$ \\
\hline \multirow{5}{*}{$\begin{array}{l}\text { Gly-OH } \\
\text { pre-reaction } \\
\text { complex }\end{array}$} & $\beta_{\mathrm{L}}$ & 1.087 & 3.161 & 1.733 \\
\hline & $\gamma_{\mathrm{L}}$ & 1.085 & 3.052 & 1.770 \\
\hline & $\gamma_{\mathrm{D}}$ & 1.084 & 3.630 & 1.803 \\
\hline & $\alpha_{\mathrm{L}}$ & 1.082 & 2.915 & 1.754 \\
\hline & $\alpha_{D}$ & 1.084 & 3.634 & 1.727 \\
\hline \multirow[t]{5}{*}{ Gly.”.OH $^{*}$} & $\beta_{\mathrm{L}}$ & 1.200 & 1.347 & 2.114 \\
\hline & $\gamma_{\mathrm{L}}$ & 1.216 & 1.316 & 2.111 \\
\hline & $\gamma_{D}$ & 1.209 & 1.330 & 2.170 \\
\hline & $\alpha_{\mathrm{L}}$ & 1.226 & 1.292 & 2.059 \\
\hline & $\alpha_{D}$ & 1.209 & 1.329 & 2.169 \\
\hline \multirow{5}{*}{$\begin{array}{l}\mathrm{Gly}-\mathrm{H}_{2} \mathrm{O} \\
\text { post-reaction } \\
\text { complex }\end{array}$} & $\beta_{\mathrm{L}}$ & 2.268 & - & 1.841 \\
\hline & $\gamma_{\mathrm{L}}$ & 1.892 & - & 1.899 \\
\hline & $\gamma_{\mathrm{D}}$ & 4.676 & - & 1.803 \\
\hline & $\alpha_{\mathrm{L}}$ & 2.997 & - & 1.946 \\
\hline & $\alpha_{D}$ & 4.680 & - & 1.803 \\
\hline \multirow{5}{*}{$\begin{array}{l}\text { Ala-OH } \\
\text { pre-reaction } \\
\text { complex }\end{array}$} & $\beta_{\mathrm{L}}$ & 1.084 & 2.934 & 1.731 \\
\hline & $\gamma_{\mathrm{L}}$ & 1.084 & 2.536 & - \\
\hline & $\gamma_{\mathrm{D}}$ & 1.081 & 3.018 & 1.719 \\
\hline & $\alpha_{\mathrm{L}}$ & 1.084 & 3.252 & 1.726 \\
\hline & $\alpha_{\mathrm{D}}$ & 1.086 & 2.453 & 5.188 \\
\hline \multirow[t]{5}{*}[\text{Ala}{}^{*}\mathrm{OH}]{$^{\ddagger}$} & $\beta_{\mathrm{L}}$ & 1.206 & 1.339 & 2.015 \\
\hline & $\gamma_{\mathrm{L}}$ & 1.207 & 1.332 & 2.063 \\
\hline & $\gamma_{\mathrm{D}}$ & 1.225 & 1.272 & 2.077 \\
\hline & $\alpha_{\mathrm{L}}$ & 1.207 & 1.334 & 2.162 \\
\hline & $\alpha_{\mathrm{D}}$ & 1.200 & 1.338 & 4.026 \\
\hline \multirow{5}{*}{$\begin{array}{l}\text { Ala- } \mathrm{H}_{2} \mathrm{O} \\
\text { post-reaction } \\
\text { complex }\end{array}$} & $\beta_{\mathrm{L}}$ & 5.156 & - & 1.845 \\
\hline & $\gamma_{\mathrm{L}}$ & 3.800 & - & 1.886 \\
\hline & $\gamma_{\mathrm{D}}$ & 4.361 & - & 1.805 \\
\hline & $\alpha_{\mathrm{L}}$ & 3.180 & - & 1.913 \\
\hline & $\alpha_{D}$ & 1.91 & - & 1.913 \\
\hline
\end{tabular}


hydrogen formed a hydrogen bond with the carbonyl carbon of residue "i -1 ". The $\gamma_{\mathrm{L}}$ and $\alpha_{\mathrm{L}}$ Gly complexes were the least stable, in spite of the fact that the distance between the hydroxy oxygen and the pro-D hydrogen was the shortest in these structures. The $\beta_{\mathrm{L}}$ and $\alpha_{\mathrm{D}}$ conformations of Gly were the most stable van der Waals complexes. The relative energy of the pre-reaction complexes are listed in Table 2, whereas the complex-formation energy values are listed in Table 5. The $\gamma_{\mathrm{L}}$ conformation formed the least-stable pre-reaction complex.

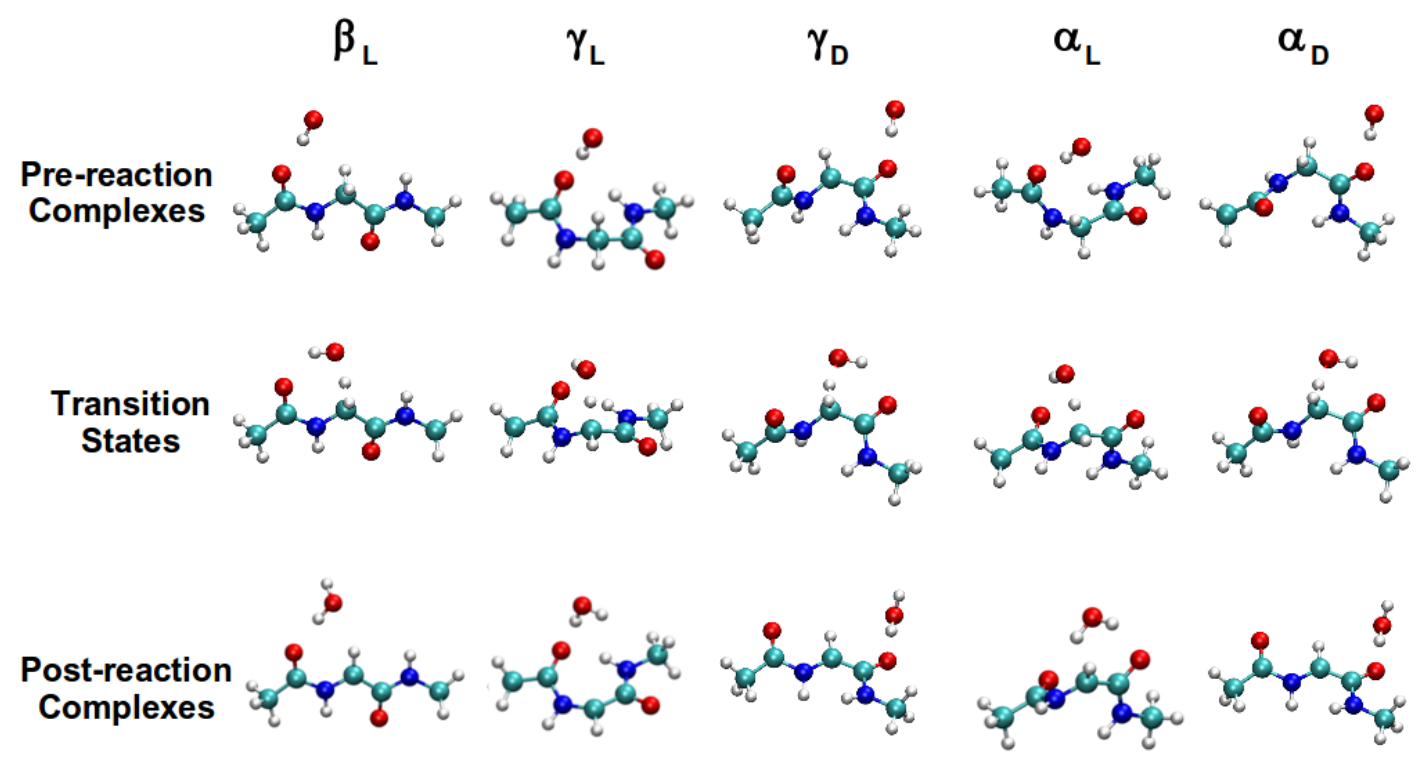

Figure 11. The pre-reaction van der Waals complexes, transition states and post-reaction complexes for the hydrogen abstraction from Gly by ${ }^{\circ} \mathrm{OH}$. The distances between the ${ }^{\circ} \mathrm{OH} / \mathrm{H}_{2} \mathrm{O}$ molecule and each conformation of the Gly/Gly' diamide are shown in Table 5.

In the Ala $\alpha_{D}$ pre-reaction complex the carbonyl oxygens of residues " $i$ " and " $i-1$ " were too far from the pro-D hydrogen to enable a hydrogen bond to form with the hydrogen atom of the hydroxy radical. This is shown in Figure 12. As such, this van der Waals complex was the least stable. The hydrogen atom of the hydroxy radical formed a hydrogen bond with the residue "i" carbonyl carbon of $\gamma_{D}$ and $\alpha_{L}$, however the $\alpha_{L}$ van der Waals complex was the 
most stable. The $\beta_{\mathrm{L}}$ van der Waals complex formed a 9-membered ring, linking the carbonyl oxygen of residue " $n-1$ " to the amide hydrogen of residue " $n+1$ ". A hydrogen bond within residue "i" remained intact.

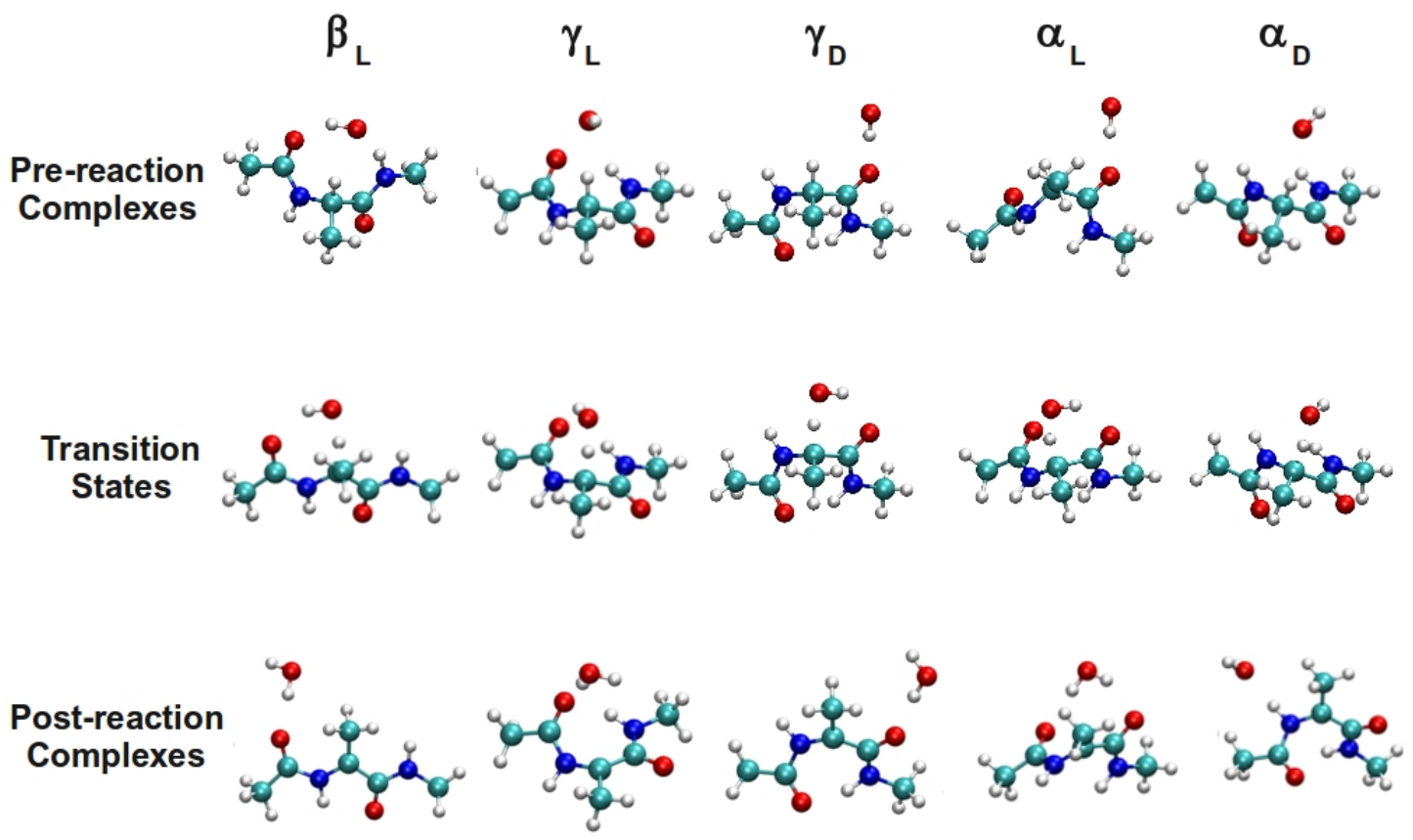

Figure 12. The pre-reaction van der Waals complexes, transition states and post-reaction complexes for the hydrogen abstraction from Ala by ${ }^{\circ} \mathrm{OH}$. The distances between the ${ }^{\circ} \mathrm{OH} / \mathrm{H}_{2} \mathrm{O}$ molecule and each conformation of the Ala/Ala diamide are shown in Table 2.

\subsubsection{The Transition State Structures}

The hydrogen atom of the ${ }^{\circ} \mathrm{OH}$ radical formed a hydrogen bond with the carbonyl carbon of the " $\mathrm{i}-1$ " residue of Gly in the transition state when Gly was in the $\beta_{\mathrm{L}}, \gamma_{\mathrm{L}}$ and $\alpha_{\mathrm{L}}$ conformations. The structure of the transition states are shown in Figure 11. The $\beta_{\mathrm{L}}$ conformation was the lowest-lying transition state, whereas the $\gamma_{\mathrm{L}}$ and $\alpha_{\mathrm{L}}$ conformations had the highest energy. The ${ }^{\circ} \mathrm{OH}$ radical completed a seven-membered ring formed a bridge between the " $\mathrm{i}-1$ " carbonyl and the $\mathrm{C}_{\alpha}$ hydrogen atom. Conversely, the hydroxyl oxygen formed a hydrogen bond of the "i"th carbonyl carbon, and therefore formed a six-membered 
Table 6. The $\phi$ and $\psi$ angles, relative potential energy, free energy, enthalpy, entropy for each of the Gly and Ala pre-reaction and post-reaction complexes and transition states with the $\mathrm{OH}$ radical. The $\beta_{\mathrm{L}}$ conformation was the reference conformation for each structure.

\begin{tabular}{|c|c|c|c|c|c|c|}
\hline Struct. & Conf. & $\phi, \psi /$ degrees & $\begin{array}{c}\Delta \mathbf{E} / \\
\mathbf{k J} \text { mol }^{-1}\end{array}$ & $\begin{array}{c}\Delta \mathbf{G}^{\mathbf{0}} / \\
\mathbf{k J} \mathbf{~ m o l}^{-1}\end{array}$ & $\underset{\mathbf{k J ~ m o l}^{-1}}{\Delta \mathbf{H}^{\mathbf{0}} /}$ & $\begin{array}{c}\Delta \mathbf{S}^{\mathbf{0}} / \\
\mathbf{J} \mathbf{m o l}^{-1} \mathbf{K}^{-1}\end{array}$ \\
\hline \multirow{5}{*}{$\begin{array}{l}\text { Gly-'OH } \\
\text { pre- } \\
\text { reaction } \\
\text { complex }\end{array}$} & $\beta_{\mathrm{L}}$ & $178.3,-176.9$ & 0.0 & 0.0 & 0.0 & 0.0 \\
\hline & $\gamma_{\mathrm{L}}$ & $-85.1,50.7$ & 10.4 & 11.2 & 9.4 & -6.2 \\
\hline & $\gamma_{\mathrm{D}}$ & $94.1,4.0$ & 0.8 & 2.8 & 14.0 & 37.8 \\
\hline & $\alpha_{\mathrm{L}}$ & $-92.2,-4.0$ & 2.7 & 3.2 & 2.6 & -2.0 \\
\hline & $\alpha_{\mathrm{D}}$ & $93.4,5.0$ & -0.9 & -2.5 & -0.9 & -5.4 \\
\hline \multirow{5}{*}[\mathrm{Gly}{}^{*\cdot}\mathrm{OH}]{$^{\ddagger}$} & $\beta_{\mathrm{L}}$ & $-174.4,-170.8$ & 0.0 & 0.0 & 0.0 & 0.0 \\
\hline & $\gamma_{\mathrm{L}}$ & $-76.2,46.5$ & 10.9 & 12.8 & 11.0 & -7.1 \\
\hline & $\gamma_{\mathrm{D}}$ & $140.4,-25.1$ & 7.5 & 5.9 & 7.5 & 0.7 \\
\hline & $\alpha_{L}$ & $-75.7,-11.3$ & 10.7 & 10.7 & 10.1 & 0.2 \\
\hline & $\alpha_{\mathrm{D}}$ & $140.4,-25.1$ & 7.5 & 5.9 & 7.5 & 7.1 \\
\hline \multirow{5}{*}{$\begin{array}{l}\text { Gly post- } \\
\text { reaction } \\
\text { complex }\end{array}$} & $\beta_{\mathrm{L}}$ & $-179.7,-179.9$ & 0.0 & 0.0 & 0.0 & 0.0 \\
\hline & $\gamma_{\mathrm{L}}$ & $-35.4,5.0$ & 35.7 & 35.6 & 20.1 & -52.0 \\
\hline & $\gamma_{\mathrm{D}}$ & $172.7,-13.2$ & 16.5 & 19.3 & 18 & -4.4 \\
\hline & $\alpha_{\mathrm{L}}$ & $-51.0,-27.4$ & 39.1 & 37.1 & 22.8 & -47.8 \\
\hline & $\alpha_{\mathrm{D}}$ & $172.6,-12.9$ & 16.6 & 12.9 & 0.9 & -40.4 \\
\hline \multirow{5}{*}{$\begin{array}{l}\text { Ala- }{ }^{-O H} \\
\text { pre- } \\
\text { reaction } \\
\text { complex }\end{array}$} & $\beta_{\mathrm{L}}$ & $-155.7,156.9$ & 0.0 & 0.0 & 0.0 & 0.0 \\
\hline & $\gamma_{\mathrm{L}}$ & $-85.8,69.0$ & 5.7 & -3.8 & -10.3 & -21.8 \\
\hline & $\gamma_{\mathrm{D}}$ & $74.0,-55.1$ & 9.0 & -1.7 & 9.4 & 37.6 \\
\hline & $\alpha_{\mathrm{L}}$ & $-80.2,-21.5$ & -0.5 & -11.8 & -16.2 & -14.9 \\
\hline & $\alpha_{\mathrm{D}}$ & $64.7,33.2$ & 32.5 & 15.9 & 31.3 & 51.7 \\
\hline \multirow[t]{5}{*}[\mathrm{Ala}\cdots\cdot\mathrm{OH}]{$^{\ddagger}$} & $\beta_{\mathrm{L}}$ & $-160.5,175.9$ & 0.0 & 0.0 & 0.0 & 0.0 \\
\hline & $\gamma_{\mathrm{L}}$ & $-78.4,52.2$ & 4.8 & 5.7 & 4.7 & -3.4 \\
\hline & $\gamma_{\mathrm{D}}$ & $78.1,-58.2$ & 3.6 & 2.7 & 3.8 & -3.6 \\
\hline & $\alpha_{\mathrm{L}}$ & $-58.4,-38.4$ & 22.3 & 15.1 & 20.7 & -18.6 \\
\hline & $\alpha_{D}$ & $64.9,32.6$ & 20.6 & 19.1 & 19.9 & 2.9 \\
\hline \multirow{5}{*}{$\begin{array}{l}\text { Ala post- } \\
\text { reaction } \\
\text { complex }\end{array}$} & $\beta_{\mathrm{L}}$ & $-170.2,176.8$ & 0.0 & 0.0 & 0.0 & 0.0 \\
\hline & $\gamma_{\mathrm{L}}$ & $-53.5,9.9$ & 20.6 & 27.0 & 4.0 & -77.3 \\
\hline & $\gamma_{\mathrm{D}}$ & $45.5,-14.0$ & 16.1 & 26.6 & 15.3 & -37.8 \\
\hline & $\alpha_{\mathrm{L}}$ & $-58.2,-25.1$ & 22.9 & 22.1 & 21.0 & -3.7 \\
\hline & $\alpha_{\mathrm{D}}$ & $56.8,18.6$ & 14.7 & 19.8 & 14.5 & -17.9 \\
\hline
\end{tabular}


ring in the transition state when the Gly residue was in the $\gamma_{D}$ and $\alpha_{D}$ conformations. The transition states that formed six-membered rings were more stable than those that were sevenmembered rings. The relative stabilities of the transition states are reported in Table 6.

Six-membered rings were formed in the $\alpha_{L}$ and $\gamma_{D}$ conformations of the transition state between the ${ }^{\circ} \mathrm{OH}$ radical and Ala. However, the $\alpha_{\mathrm{L}}$ transition state was more stable, and this is probably due to the hydrogen bond that formed between the " $\mathrm{i}-1$ " carbonyl oxygen and " $\mathrm{i}$ + 1" amide hydrogen. The structures of the Ala transition states are also shown in Figure 12. The steric hindrance caused by the methyl group of Ala prevented the formation of ring structures for the $\alpha_{\mathrm{D}}$ transition state. The hydrogen of the ${ }^{\circ} \mathrm{OH}$ radical may be interacting with the amide nitrogen in the case of the $\alpha_{D}$ and conformation, since the distance between these atoms is approximately $3.4 \AA$. These values can be found in Table 5. The $\beta_{\mathrm{L}}$ transition state was the lowest-lying Ala transition state, whereas the $\alpha_{D}$ and $\alpha_{L}$ were the highest in energy.

\subsubsection{The Post-Reaction Complexes}

The water molecule that forms after the hydrogen atom is abstracted from Gly forms a hydrogen bond between $1.80 \AA$ and $1.95 \AA$ in length with a carbonyl carbon. These values are listed in Table 5. The $\gamma_{\mathrm{D}}$ and $\alpha_{\mathrm{D}}$ transition states formed the same van der Waals complex, with $\phi$ and $\psi$ angels close to $173^{\circ}$ and $-13^{\circ}$, respectively, and their conformation is similar to that of the $\gamma_{\mathrm{D}}$ conformation observed in the Gly in the absence of $\mathrm{H}_{2} \mathrm{O}$. The relative energy of these van der Waals complex $\left(16.5 \mathrm{~kJ} \mathrm{~mol}^{-1}\right.$, Table 6) is also similar to that of the $\gamma_{\mathrm{D}}$ conformation of the Gly $\left(21.0 \mathrm{~kJ} \mathrm{~mol}^{-1}\right.$, Table 4), indicating that the $\mathrm{H}_{2} \mathrm{O}$ molecule has a 
small effect on the relative stabilities of the complexes. Both the relative energies and $\phi$ and $\psi$ angles of the van der Waals complexes are shown in Table 6. However, the $\gamma_{\mathrm{L}}$ and $\alpha_{\mathrm{L}}$ transition states $\left(35.7 \mathrm{~kJ} \mathrm{~mol}^{-1}\right.$ and $39.1 \mathrm{~kJ} \mathrm{~mol}^{-1}$, respectively) converged to van der Waals complexes that were similar in structure to the $\gamma_{\mathrm{L}}$ conformation of Gly: The $\beta_{\mathrm{L}}$ van der Waals complex was the most stable and the $\phi$ and $\psi$ angles of the Gly were $-179.7^{\circ}$ and $-179.9^{\circ}$, respectively. The water molecule in the Gly complexes stabilized the $\alpha_{\mathrm{L}}$ and $\alpha_{\mathrm{D}}$ conformations more than the others.

The $\beta_{\mathrm{L}}$ post reaction van der Waals complex of Ala ${ }^{\circ}$ was the most stable. The $\phi$ and $\psi$ angles of the complex were $-170.2^{\circ}$ and $176.8^{\circ}$, respectively, which deviated slightly from the $\phi$ and $\psi$ angles of $\mathrm{Ala} a^{\circ}$ in the absence of water, $\left(-171.9^{\circ}\right.$ and $\left.176.7^{\circ}\right)$. The $\gamma_{\mathrm{L}}$ and $\alpha_{\mathrm{L}}$ conformations were similar in energy, whereas the $\gamma_{D}$ and $\alpha_{D}$ conformations were similar to each other in energy, and more stable than the $\gamma_{L}$ and $\alpha_{L}$ conformations. This energy difference can be attributed to the orientation of the water molecule. One of the hydrogen atoms of $\mathrm{H}_{2} \mathrm{O}$ was $2.08 \AA$ above the " $\mathrm{i}+1$ " amide nitrogen, which was hydrogen bonded to the amide nitrogen. However, this water orientation was also observed in the $\beta_{\mathrm{L}}$ conformation, which was the most stable. The closest distance between the oxygen of the water molecule and the carbon of the Ala side chain is $3.62 \AA$ and $3.64 \AA$, in the $\alpha_{L}$ and $\gamma_{D}$ conformations, respectively.

\subsubsection{Relative Energies of Gly and Ala H-Abstraction Reactions}

Table 7 contains the energy of the pre-reaction van der Waals complex, transition state and post-reaction complex for each of the conformations of Gly, Gly', Ala and Ala: The 
energy values are relative to the sum of the energies of the respective Gly and Ala conformation and an infinitely separated ${ }^{\circ} \mathrm{OH}$ radical. The relative energy of the pre-reaction van der Waals complexes of Gly was between $-19.0 \mathrm{~kJ} \mathrm{~mol}^{-1}$ and $-29.4 \mathrm{~kJ} \mathrm{~mol}^{-1}$, whereas the Ala values were between $-1.4 \mathrm{~kJ} \mathrm{~mol}^{-1}$ and $-25.9 \mathrm{~kJ} \mathrm{~mol}^{-1}$. The formation of the $\gamma_{\mathrm{D}}$ prereaction complex of Gly was the most favorable. Moreover, the $\gamma_{D}$ and $\alpha_{D}$ conformations of the Gly pre-reaction complexes were more stable than the respective $\gamma_{\mathrm{L}}$ and $\alpha_{\mathrm{L}}$ conformations.

Table 7. The $\Delta \mathrm{E}$ and $\Delta \mathrm{G}^{0}$ of the pre-reaction complexes, transition states, and post-reaction complexes relative to the those of the reactants of the hydrogen abstraction reactions from Gly and Ala by ${ }^{\circ} \mathrm{OH}$ and the subsequent abstraction of hydrogen from $\mathrm{H}_{2} \mathrm{O}_{2}$ by Gly and Ala:

\begin{tabular}{|c|c|c|c|c|c|}
\hline \multirow[t]{2}{*}{ Reaction } & \multirow[t]{2}{*}{ Conf } & \multicolumn{4}{|c|}{$\Delta \mathbf{E}^{0}\left(\Delta \mathbf{G}^{0}\right) / \mathbf{k J ~ m o l}^{-1}$} \\
\hline & & $\begin{array}{l}\text { Pre-reaction } \\
\text { complex }\end{array}$ & Transition State & $\begin{array}{l}\text { Post-reaction } \\
\text { complex }\end{array}$ & Products \\
\hline \multirow{5}{*}{$\begin{array}{c}\text { Gly }+{ }^{\cdot} \mathrm{OH} \rightarrow \\
\text { Gly }^{\circ}+\mathrm{H}_{2} \mathrm{O}\end{array}$} & $\beta_{\mathrm{L}}$ & $-24.5(9.2)$ & $-0.8(32.9)$ & $-159.8(-124.0)$ & $-144.7(-148.0)$ \\
\hline & $\gamma_{\mathrm{L}}$ & $-19.0(10.9)$ & $6.2(36.2)$ & $-127.9(-98.0)$ & \\
\hline & $\gamma_{\mathrm{D}}$ & $-29.4(2.5)$ & $2.8(29.3)$ & $-147.1(-118.8)$ & \\
\hline & $\alpha_{\mathrm{L}}$ & $-21.4(12.5)$ & $9.8(43.7)$ & $-120.7(-86.9)$ & \\
\hline & $\alpha_{D}$ & $-25.5(6.9)$ & $6.5(38.9)$ & $-143.3(-110.9)$ & \\
\hline \multirow{5}{*}{$\begin{array}{c}\mathrm{Ala}+{ }^{\bullet} \mathrm{OH} \rightarrow \\
\mathrm{Ala}^{\cdot}+\mathrm{H}_{2} \mathrm{O}\end{array}$} & $\beta_{\mathrm{L}}$ & $-24.4(19.6)$ & $-1.1(32.4)$ & $-156.4(-128.3)$ & $-141.7(-148.8)$ \\
\hline & $\gamma_{\mathrm{L}}$ & $-19.9(11.8)$ & $2.4(34.1)$ & $-137.1(-105.3)$ & \\
\hline & $\gamma_{D}$ & $-25.9(23.2)$ & $8.9(35.2)$ & $-152.3(-124.8)$ & \\
\hline & $\alpha_{\mathrm{L}}$ & $-24.1(7.4)$ & $3.1(34.7)$ & $-139.6(-102.2)$ & \\
\hline & $\alpha_{D}$ & $-1.4(23.1)$ & $11.6(35.2)$ & $-143.1(-118.5)$ & \\
\hline $\begin{array}{c}\mathrm{Gly}^{\circ}+\mathrm{H}_{2} \mathrm{O}_{2} \\
\text { Gly }+\mathrm{HO}_{2}\end{array}$ & $\beta_{\mathrm{L}}$ & $-23.3(9.3)$ & $55.6(94.8)$ & $-53.3(-2.1)$ & $-15.9(-11.1)$ \\
\hline $\begin{array}{c}\mathrm{Ala}+\mathrm{H}_{2} \mathbf{O}_{2} \rightarrow \\
\mathrm{Ala}+\mathrm{HO}_{2}\end{array}$ & $\beta_{\mathrm{L}}$ & $-23.1(18.5)$ & $50.8(101.7)$ & $-55.9(-5.1)$ & $-18.8(-10.3)$ \\
\hline
\end{tabular}

The $\gamma_{\mathrm{L}}$ and $\alpha_{\mathrm{D}}$ pre-reaction complexes of Ala were the least stable.

The $\beta_{\mathrm{L}}$ conformations of Gly and Ala were the lowest-lying transition states, which were 
approximately $1 \mathrm{~kJ} \mathrm{~mol}^{-1}$ lower in energy than the respective conformation of the reactant and the ${ }^{\circ} \mathrm{OH}$ radical. All of the other transition states had positive activation energies. The $\alpha_{\mathrm{L}}$ transition state of Ala and the $\gamma_{\mathrm{D}}$ transition state of Gly were the next lowest-lying of the respective structures, and were within $3 \mathrm{~kJ} \mathrm{~mol}^{-1}$ of the $\beta_{\mathrm{L}}$ energies. The $\beta_{\mathrm{L}}$ conformation of Gly post-reaction complex was the most stable, which was approximately $11 \mathrm{~kJ} \mathrm{~mol}^{-1}$ more stable than that of the $\gamma_{D}$ conformation, which had the second highest relative stability. Interresidue comparison shows that the $\beta_{\mathrm{L}}$ post-reaction complex of Gly was only $2.4 \mathrm{~kJ} \mathrm{~mol}^{-1}$ more stable than the $\beta_{\mathrm{L}}$ conformation of the Ala ${ }^{\circ}$ post-reaction complex, which had the highest relative stability for Ala:

Given the relative stability of the $\beta_{\mathrm{L}}$ conformation of Gly and Ala ${ }^{\circ}$ in the absence of $\mathrm{H}_{2} \mathrm{O}$, the sum of the energy of the respective structures in the $\beta_{\mathrm{L}}$ conformation and that of $\mathrm{H}_{2} \mathrm{O}$ was used to represent the energy of the dissociated products, which was $-144.7 \mathrm{~kJ} \mathrm{~mol}^{-1}$ for Gly + $\mathrm{H}_{2} \mathrm{O}$ and $-141.7 \mathrm{~kJ} \mathrm{~mol}^{-1}$ for Ala $+\mathrm{H}_{2} \mathrm{O}$. The $\beta_{\mathrm{L}}$, and $\gamma_{\mathrm{D}}$ van der Waals complexes are more stable than the dissociated Gly and $\mathrm{H}_{2} \mathrm{O}$, whereas the $\gamma_{\mathrm{L}}, \alpha_{\mathrm{L}}$ and $\alpha_{\mathrm{D}}$ complexes are not. In the case of Ala, the $\beta_{L}, \alpha_{D}$ and $\gamma_{D}$ complexes are more stable than the dissociated Ala ${ }^{\circ}$ and $\mathrm{H}_{2} \mathrm{O}$, whereas the $\gamma_{\mathrm{L}}$ and $\alpha_{\mathrm{L}}$ were less stable than the dissociated Ala and $\mathrm{H}_{2} \mathrm{O}$.

\subsubsection{Reforming Gly and Ala through Hydrogen Abstraction from $\mathrm{H}_{2} \mathrm{O}_{2}$}

After being chemically activated by the ${ }^{\circ} \mathrm{OH}$ radical, the formation of Gly and Ala ${ }^{\circ}$ radicals from the Gly and Ala residues resulted in $144.7 \mathrm{~kJ} \mathrm{~mol}^{-1}$ and $141.7 \mathrm{~kJ} \mathrm{~mol}^{-1}$ to be released in the case of Gly and Ala, respectively. The formation of the Gly ${ }^{\bullet}-\mathrm{H}_{2} \mathrm{O}_{2}$ and Ala $\mathrm{H}_{2} \mathrm{O}_{2}$ pre-reaction complexes released $24.8 \mathrm{~kJ} \mathrm{~mol}^{-1}$ of energy in the case of Gly and $23.3 \mathrm{~kJ}$ 
$\mathrm{mol}^{-1}$ for Ala: These values can be found in Table 7. The transition state also had similar relative energies; however, the Ala transition state was approximately $5 \mathrm{~kJ} \mathrm{~mol}^{-1}$ higher than that of Gly. The geometry of the Ala ${ }^{\circ}$ and Gly transition state structures are shown in Figure 13. An eight-membered ring was formed between $\mathrm{H}_{2} \mathrm{O}_{2}$ and Ala. A similar structure was observed for the Gly residue, however, the distance between the carbonyl carbon and $\mathrm{H}_{2} \mathrm{O}_{2}$ molecule was $0.9 \AA$ larger in the Gly transition state. Moreover, the post-reaction Ala van der Waals complex $\left(-2.6 \mathrm{~kJ} \mathrm{~mol}^{-1}\right)$ and the infinitely separated Ala and $\mathrm{HO}_{2} \cdot\left(-2.9 \mathrm{~kJ} \mathrm{~mol}^{-1}\right)$ were more stable than the respective Gly structures by $2.6 \mathrm{~kJ} \mathrm{~mol}^{-1}$ and $2.9 \mathrm{~kJ} \mathrm{~mol}^{-1}$, respectively. The post-reaction van der Waals structures of both Gly and Ala were more stable than the respective non-interacting products.

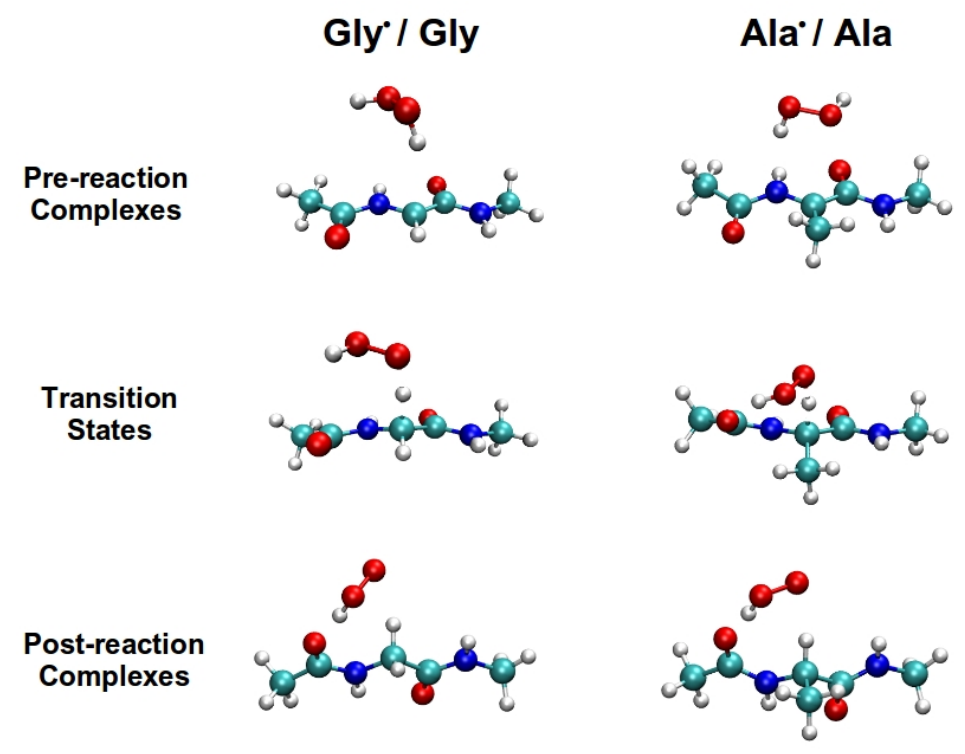

Figure 13. The pre-reaction van der Waals complexes, transition states and post-reaction complexes for the hydrogen abstraction from $\mathrm{H}_{2} \mathrm{O}_{2}$ by Gly' and Ala'.

During the reaction in which $\mathrm{H}_{2} \mathrm{O}_{2}$ regenerates Gly, the energy stays well below the energy of the entrance level, which is the sum of the energy of ${ }^{\circ} \mathrm{OH}$ and the Gly residue. This 
is shown in Figure 14. The transition state of the hydrogen abstraction reaction between Gly' and $\mathrm{H}_{2} \mathrm{O}_{2}$ is approximately $90 \mathrm{~kJ} \mathrm{~mol}^{-1}$ lower in energy than the energy of the entrance level, which suggests that the subsequent reaction with $\mathrm{H}_{2} \mathrm{O}_{2}$ can take place following activation by $\cdot \mathrm{OH}$.

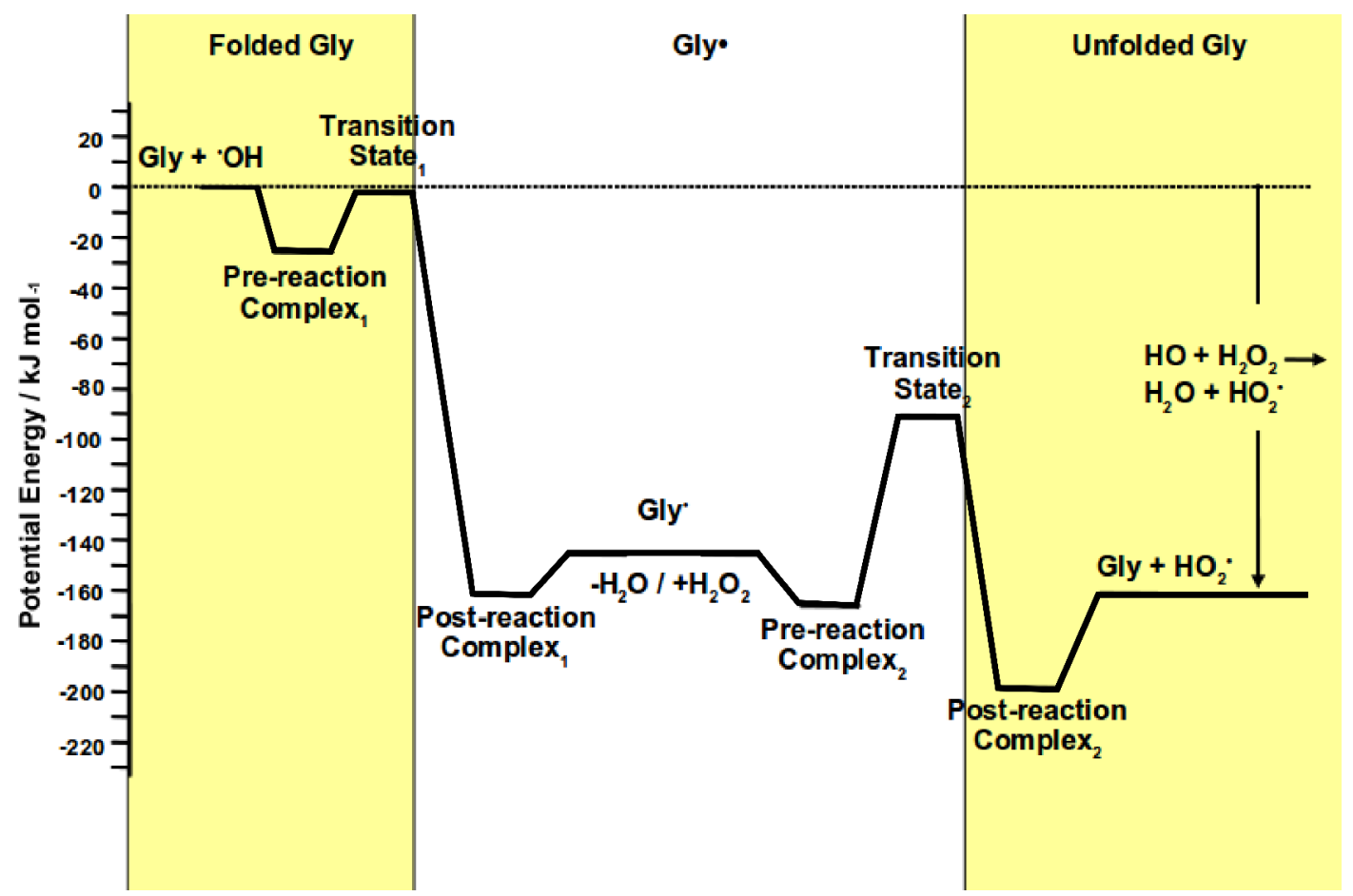

Figure 14. The reaction coordinate diagram showing the $\mathrm{E}_{\mathrm{pot}}$ of the hydrogen abstraction from Gly in the $\beta_{\mathrm{L}}$ conformation by ${ }^{\circ} \mathrm{OH}$ and the subsequent hydrogen abstraction from $\mathrm{H}_{2} \mathrm{O}_{2}$ by Gly and Ala in the $\beta_{\mathrm{L}}$ conformation. The sum of the energy of Gly and ${ }^{\circ} \mathrm{OH}$ is used as a reference, which shows that energy of the two reactions stays below the energy of the entrance level.

\subsection{Structural analysis of the Pentapeptides}

The structures of the $\mathrm{G} 5\left(\mathrm{C}_{\alpha}{ }^{\circ}\right)$ and $\mathrm{G} 5\left(\mathrm{~N}^{*}\right)$ peptides will be compared to the $\mathrm{G} 5$ peptide in the subsequent sections. Figure $\mathbf{1 5}$ shows a schematic diagram of G5, and the positions from which hydrogen atoms were removed to yield the peptide radicals. 


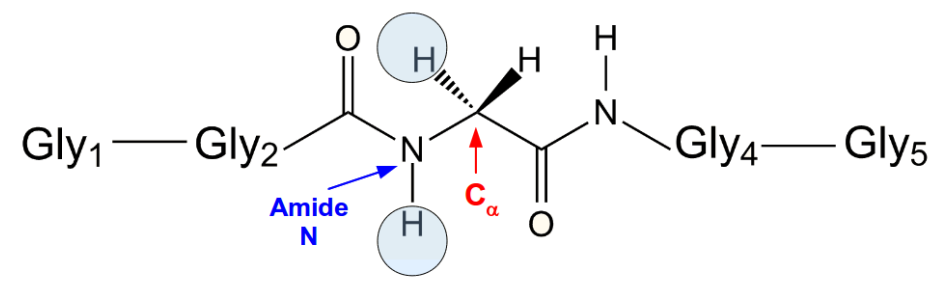

Figure 15. A schematic representation of the G5 peptide and the position of the hydrogen atoms before abstraction.

\subsubsection{Comparison of G5 to the G5 Peptide Radicals}

\subsubsection{The G5 Structure}

The extended conformation of the G5 peptide was conserved during the optimizations at both levels of theory and in both the gas phase and the simulated aqueous environment. A list of geometric parameters can be found in Table 8 and Table 9. The $\phi$ and $\psi$ angles were within $0.4^{\circ}$ of $180.0^{\circ}$, indicating that the peptide remained fully extended, and also caused the peptide to remain flat, as shown in Figure 15. This structure was stabilized with hydrogen bonds between the amide nitrogen and carbonyl oxygen of neighboring residues.

In the case of the $3_{10}$ helix, the hydrogen bonds between " $i$ " and " $i+2$ " residues remained intact during the optimizations at both levels of theory and in both environments, thus conserving the $3_{10}$ helical conformation.

\subsubsection{Deviations from the G5 Structure}

The structural perturbations resulting from $\mathrm{H}$-Abstraction from the $\mathrm{C}_{\alpha}$ and amide nitrogen of residue 3 in G5 will be described in the subsequent sections.

\subsubsection{The Effect of H-Abstraction from the $\mathrm{C}_{\alpha}$ of G5}

The removal of a hydrogen atom from the $\mathrm{C}_{\alpha}$ decreased the length of the bonds between 
the $\mathrm{C}_{\alpha}$ and the amide nitrogen, $\mathrm{C}_{\alpha}$ hydrogen and carbonyl carbon atoms in the gas phase by $0.079 \AA, 0.016 \AA$ and $0.077 \AA$, respectively, (Table 8) when G5 is in the extended conformation. The length of the amide bond between $\mathrm{Gly}^{3}$ and Gly ${ }^{2}$ increased by $0.025 \AA$, whereas the length of the bond between $\mathrm{Gly}^{3}$ and Gly ${ }^{4}$ increased by $0.011 \AA$. The respective amide bonds increased by $0.030 \AA$ and $0.015 \AA$ when the structures were optimized in the implicit solvent.

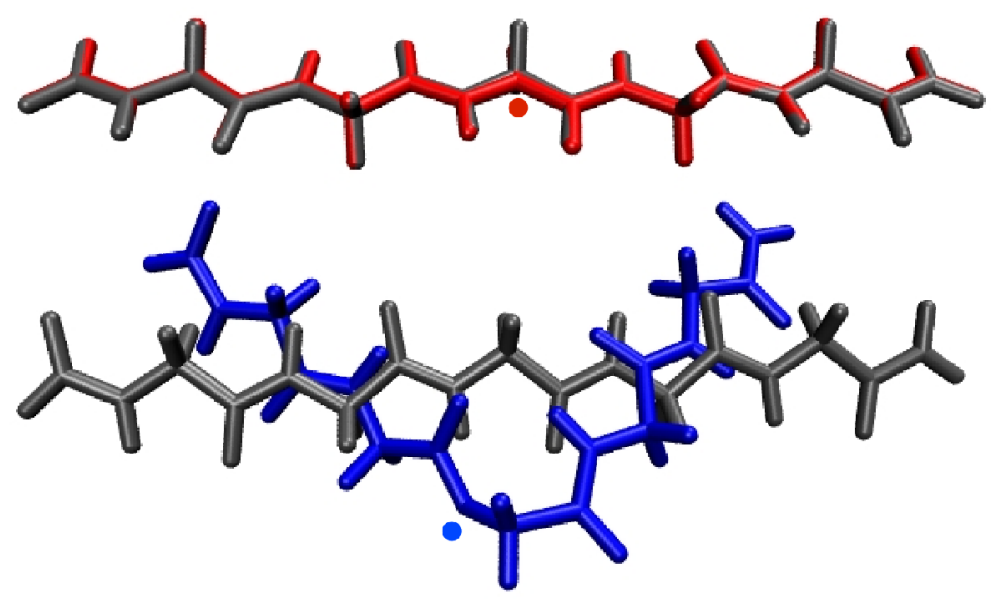

Figure 16. Structural alignment of the G5 peptide and the G5 peptide radicals in the extended conformation. The structures were obtained at the B3LYP/6-311+G(d,p) level of theory in the gas phase. The $\mathrm{G} 5\left(\mathrm{C}_{\alpha}{ }^{\circ}\right)$ peptide is shown in red, the $\mathrm{G} 5\left(\mathrm{~N}^{*}\right)$ is shown in blue and the $\mathrm{G} 5$ peptide is shown in gray.

Hydrogen atom abstraction from the $\mathrm{C}_{\alpha}$ of $\mathrm{Gly}^{3}$ also increased the length of the bond between the $\mathrm{C}_{\alpha}$ and the amide nitrogen, $\mathrm{C}_{\alpha}$ hydrogen and carbonyl carbon atoms in the helical conformation, as shown in Figure 16. The length of these bonds increased by $0.071 \AA, 0.011$ $\AA$ and $0.074 \AA$, respectively. The length of the amide bond between $\mathrm{Gly}^{2}$ and $\mathrm{Gly}^{3}$ increased by $0.017 \AA$, whereas the length of the amide bond between $\mathrm{Gly}^{3}$ and $\mathrm{Gly}^{4}$ increased by 0.010 $\AA$. The respective amide bond lengths increased by $0.028 \AA$ and $0.012 \AA$ in the implicit 
Table 8. Bond lengths in $\mathrm{Gly}^{3}$ of $\mathrm{G} 5, \mathrm{~A}\left(\mathrm{C}_{\alpha}{ }^{\circ}\right)$ and $\mathrm{A}\left(\mathrm{N}^{*}\right)$ in the extended and helical conformations. The bond lengths were computed at the B3LYP/6$31 \mathrm{G}(\mathrm{d})$ and B3LYP/6-311+G(d,p) (shown in parentheses) levels of theory, both and in the gas phase and implicit solvent.

\begin{tabular}{|c|c|c|c|c|c|c|c|c|}
\hline \multirow{2}{*}{ Peptide } & \multirow{2}{*}{ Environment } & \multicolumn{7}{|c|}{ Bond Length / Å } \\
\hline & & " $n-1$ " amide & $\mathrm{N}-\mathrm{C}_{\alpha}$ & $\mathrm{N}-\mathrm{H}$ & $\mathrm{C}_{\alpha}-\mathrm{H}$ & $\mathrm{C}_{\alpha}-\mathrm{C}$ & $\mathrm{C}=\mathrm{O}$ & "n +1 " amide \\
\hline \multirow{2}{*}{$\mathrm{G}_{\mathrm{Ext}}$} & Gaseous & $1.349(1.349)$ & $1.444(1.445)$ & $1.016(1.014)$ & $1.098(1.095)$ & $1.533(1.53)$ & $1.444(1.445)$ & 1.349 (1.349) \\
\hline & Aqueous & $1.343(1.342)$ & $1.446(1.447)$ & $1.015(1.013)$ & $1.097(1.094)$ & $1.532(1.53)$ & $1.446(1.447)$ & $1.343(1.342)$ \\
\hline \multirow{2}{*}{$\mathrm{G}\left(\mathrm{C}_{\alpha}\right)_{\mathrm{Ext}}$} & Gaseous & $1.372(1.374)$ & $1.367(1.366)$ & $1.020(1.018)$ & $1.080(1.079)$ & $1.454(1.453)$ & $1.367(1.366)$ & $1.360(1.360)$ \\
\hline & Aqueous & $1.371(1.372)$ & $1.367(1.365)$ & $1.019(1.017)$ & $1.080(1.078)$ & $1.452(1.45)$ & $1.367(1.365)$ & $1.358(1.357)$ \\
\hline \multirow{2}{*}{$\mathrm{G}\left(\mathrm{N}^{\bullet}\right)_{\mathrm{Ext}}$} & Gaseous & $1.373(1.374)$ & $1.428(1.427)$ & - & $1.090(1.096)$ & $1.584(1.581)$ & $1.428(1.427)$ & $1.344(1.344)$ \\
\hline & Aqueous & $1.375(1.375)$ & $1.433(1.434)$ & - & $1.091(1.09)$ & $1.575(1.567)$ & $1.433(1.434)$ & $1.342(1.340)$ \\
\hline \multirow{2}{*}{$\mathrm{G}_{\mathrm{Hel}}$} & Gaseous & $1.355(1.354)$ & $1.453(1.454)$ & $1.015(1.013)$ & $1.093(1.091)$ & $1.537(1.535)$ & $1.453(1.454)$ & 1.355 (1.354) \\
\hline & Aqueous & $1.351(1.348)$ & $1.450(1.451)$ & $1.018(1.016)$ & $1.093(1.091)$ & $1.533(1.531)$ & $1.450(1.451)$ & $1.351(1.349)$ \\
\hline \multirow{2}{*}{$\mathrm{G}\left(\mathrm{C}_{\alpha}\right)_{\mathrm{Hel}}$} & Gaseous & $1.378(1.371)$ & $1.387(1.383)$ & $1.020(1.019)$ & $1.083(1.08)$ & $1.463(1.461)$ & $1.387(1.383)$ & $1.366(1.364)$ \\
\hline & Aqueous & $1.377(1.376)$ & $1.382(1.38)$ & $1.023(1.02)$ & $1.080(1.081)$ & $1.460(1.458)$ & $1.382(1.38)$ & $1.363(1.361)$ \\
\hline \multirow{2}{*}{$\mathrm{G}\left(\mathrm{N}^{*}\right)_{\mathrm{Hel}}$} & Gaseous & $1.363(1.360)$ & $1.431(1.428)$ & - & $1.097(1.095)$ & $1.541(1.54)$ & $1.431(1.428)$ & $1.351(1.350)$ \\
\hline & Aqueous & $1.366(1.362)$ & $1.432(1.431)$ & - & $1.104(1.096)$ & $1.541(1.535)$ & $1.432(1.431)$ & $1.347(1.345)$ \\
\hline
\end{tabular}

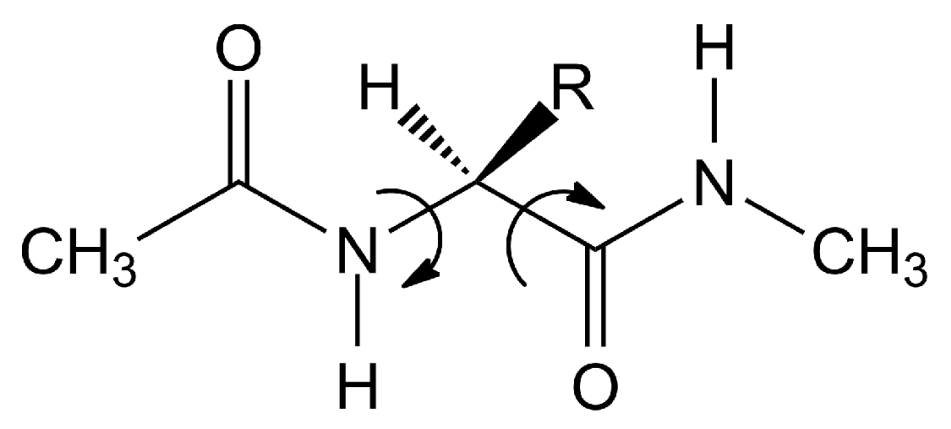


solvent.

The $\phi$ and $\psi$ angles remained within one degree of full extension $\left(180^{\circ}\right)$ in the gas phase and implicit solvent, and this was also observed when both basis sets were used. The intraresidue hydrogen bond of the extended structure is $0.074 \AA$ and $0.126 \AA$ longer than the corresponding bond in G5 in the gas phase and implicit solvent, respectively, and these bonds were slightly shorter when the 6-31G(d) basis set was used.

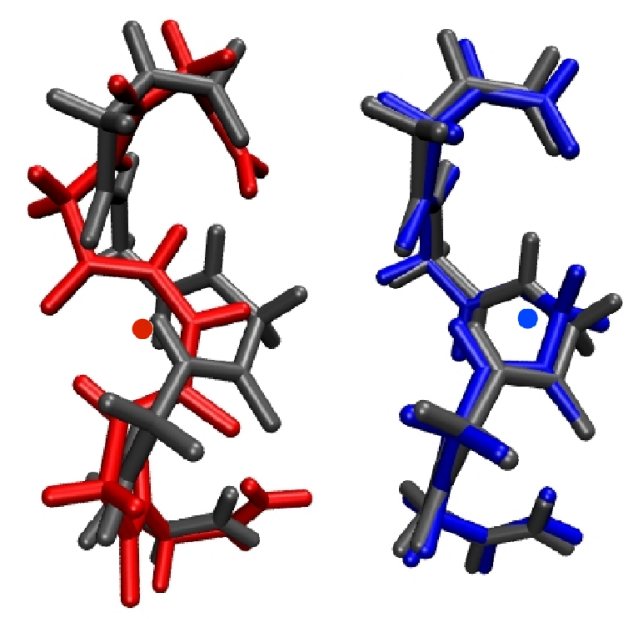

Figure 17. Structural alignment of the G5 peptide and the G5 peptide radicals in the helical conformation. The structures were obtained at the B3LYP/6-311+G(d,p) level of theory in the gas phase. The $\mathrm{G} 5\left(\mathrm{C}_{\alpha}{ }^{\circ}\right)$ peptide is shown in red, the $\mathrm{G} 5\left(\mathrm{~N}^{*}\right)$ is shown in blue and the G5 peptide is shown in gray.

Hydrogen abstraction from the $\mathrm{C}_{\alpha}$ in the helical conformation caused the $\phi$ and $\psi$ angles to go from $-62.91^{\circ}$ and $-18.53^{\circ}$, to $0.11^{\circ}$ and $2.87^{\circ}$, respectively, and an intra-residue hydrogen bond formed between the amide hydrogen and the carbonyl carbon of $2.221 \AA$. These results are shown in Figure 17. Hydrogen abstraction caused the $\phi$ angle to decreased 
by approximately $20^{\circ}$ in the implicit solvent, whereas the change in the $\psi$ angle was negligible. Moreover, the hydrogen bond between the amide nitrogen of Gly ${ }^{3}$ and carbonyl carbon of $\mathrm{Gly}^{1}$ dissociated and the intra-residue hydrogen bond of $2.221 \AA$ formed between the amide hydrogen and carbonyl oxygen. The hydrogen bond between the amide nitrogen of Gly and carbonyl oxygen of Gly ${ }^{1}$ and that between the carbonyl oxygen of Gly ${ }^{3}$ and the amide nitrogen of $\mathrm{Gly}^{5}$ were conserved in the aqueous phase and when the smaller basis set was used. The RMSD of the peptide backbone atoms of the $\mathrm{C}_{\alpha}$ peptide radical from those of G5 was $0.0725 \AA$ and $0.132 \AA$ in the gas phase and implicit solvent, respectively. The corresponding deviations in the helical conformation were $0.322 \AA$ and $0.279 \AA$.

\subsubsection{The Effect of H-Abstraction from the Amide Nitrogen of G5}

The removal of the hydrogen atom from the amide nitrogen of the extended G5 caused the length of the bond between the amide $\mathrm{N}$ and the $\mathrm{C}_{\alpha}$ to decrease by $0.018 \AA$, whereas the subsequent bond between the $\mathrm{C}_{\alpha}$ and the carbonyl carbon increased by $0.051 \AA$. This data is shown in Table 9. In the helical G5(N*), the decrease in the $\mathrm{N}-\mathrm{C}_{\alpha}$ bond length was $0.026 \AA$ and the increase in the $\mathrm{C}_{\alpha}-\mathrm{C}=\mathrm{O}$ bond length was $0.050 \AA$. In both conformations the length of the amide bonds between $\mathrm{Gly}^{3}$ and $\mathrm{Gly}^{2}$ and those between Gly ${ }^{3}$ and Gly increased. The length of the amide bond between $\mathrm{Gly}^{3}$ and Gly ${ }^{2}$ increased by $0.026 \AA$ in the extended conformation and $0.006 \AA$ in the helical. The increase in the length of the bond between $\mathrm{Gly}^{3}$ and $\mathrm{Gly}^{4}$ was $0.005 \AA$ in the extended conformation and $0.004 \AA$ in the helical conformation. 
Table 9. The $\phi$ and $\psi$ dihedral angles and H-bond distances of $\mathrm{Gly}^{3}$ in G5 and the peptide radicals in the extended and helical conformations. The geometric parameters were computed at the B3LYP/6-31G(d) and B3LYP/6-311+G(d,p) (shown in parentheses) levels of theory, both and in the gas phase and implicit solvent. The RMSD of the backbone atoms for the peptide radicals compared to those of G5 are also shown.

\begin{tabular}{ccccccc}
\hline \multirow{2}{*}{ Peptide } & Condition & \multicolumn{2}{c}{ Dihedral Angle } & \multicolumn{2}{c}{ Hydrogen bond length } & Backbone \\
\cline { 3 - 6 } & & $\phi /$ degrees & $\psi /$ degrees & Amide H & Carbonyl O & RMSD / \\
\hline $\mathrm{G}_{\mathrm{Ext}}$ & Gaseous & $179.5(179.9)$ & $-179.7(-179.9)$ & $2.11(2.14)$ & $2.11(2.14)$ & $0.00(0.00)$ \\
& Aqueous & $179.2(179.7)$ & $-179.4(-179.4)$ & $2.12(2.16)$ & $2.12(2.16)$ & $0.00(0.00)$ \\
$\mathrm{G}_{\left.\left(\mathrm{C}_{\alpha}\right)_{\mathrm{E}}\right)_{\mathrm{E}}}$ & Gaseous & $179.8(-179.9)$ & $179.9(-179.9)$ & $2.18(2.22)$ & $2.18(2.22)$ & $0.12(0.072)$ \\
$\mathrm{xt}$ & Aqueous & $-179.8(-179.9)$ & $-179.9(-179.9)$ & $2.24(2.29)$ & $2.24(2.29)$ & $0.11(0.13)$ \\
$\mathrm{G}_{\mathrm{G}\left(\mathrm{N}^{*}\right)_{\mathrm{Ext}}}$ & Gaseous & $-96.6(-97.8)$ & $61.1(60.5)$ & - & - & $2.86(2.82)$ \\
& Aqueous & $-99.5(-102.8)$ & $63.6(66.9)$ & - & - & $2.80(2.61)$ \\
$\mathrm{G}_{\mathrm{Hel}}$ & Gaseous & $-62.1(-62.9)$ & $-19.0(-18.5)$ & $2.07(2.12)$ & $2.15(2.12)$ & $0.00(0.00)$ \\
& Aqueous & $-60.5(-61.9)$ & $-21.5(-20.1)$ & $2.01(2.08)$ & $2.06(2.15)$ & $0.00(0.00)$ \\
$\mathrm{G}\left(\mathrm{C}_{\alpha}\right)_{\mathrm{H}}$ & Gaseous & $-38.9(0.1)$ & $-23.8(2.87)$ & $2.07(2.05)$ & $2.13(2.08)$ & $0.38(1.99)$ \\
$\mathrm{el}$ & Aqueous & $-39.9(-40.7)$ & $-23.3(-24.1)$ & $2.03(2.10)$ & $2.04(2.11)$ & $0.33(0.32)$ \\
$\mathrm{G}\left(\mathrm{N}^{*}\right)_{\mathrm{Hel}}$ & Gaseous & $-3.4(-3.3)$ & $-52.5(-51.8)$ & - & $2.15(2.22)$ & $0.28(0.27)$ \\
& Aqueous & $6.4(6.4)$ & $-58.2(-47.3)$ & - & $2.06(2.13)$ & $0.29(0.48)$ \\
\hline
\end{tabular}

In the extended structure, the absence of the $\mathrm{H}$ atom in the amide nitrogen prevents the formation of the intra-residue hydrogen bond; however, a hydrogen bond was formed between the carbonyl oxygen of $\mathrm{Gly}^{2}$ and the amide nitrogen of $\mathrm{Gly}^{4}$. It is suspected that this contributes to the $\approx 80^{\circ}$ and $120^{\circ}$ respective differences between the $\phi$ and $\psi$ angles of the native G5 peptide in the extended conformation and those of the extended G5(N*) (Table 9). This change in hydrogen bonding is reflected in the RMSD, which showed that the backbone of the extended $\mathrm{G} 5\left(\mathrm{~N}^{*}\right)$ deviated from the backbone of the G5 peptide by $2.82 \AA$. In the helical G5( $\left.\mathrm{N}^{*}\right), \mathrm{H}$-abstraction from the amide nitrogen eliminated the hydrogen bond with the carbonyl carbon of Gly ${ }^{1}$. The loss of the hydrogen bond resulted in a decrease in the $\phi$ angle of approximately $60^{\circ}$, whereas the $\psi$ angle changed by approximately $10^{\circ}$. These 
perturbations in structure was also shown in the RMSD analysis, however this deviation was only $0.279 \AA$.

\subsubsection{Comparison of A5 to the A5 Peptide Radicals}

The structures of the $\mathrm{A} 5\left(\mathrm{C}_{\alpha}{ }^{\cdot}\right), \mathrm{A} 5\left(\mathrm{C}_{\beta}{ }^{\circ}\right)$ and $\mathrm{A} 5\left(\mathrm{~N}^{*}\right)$ peptides are compared to the $\mathrm{A} 5$ peptide in the subsequent sections. Figure $\mathbf{1 8}$ shows a schematic diagram of A5, and the positions from which hydrogen atoms were removed to yield the corresponding peptide radicals.

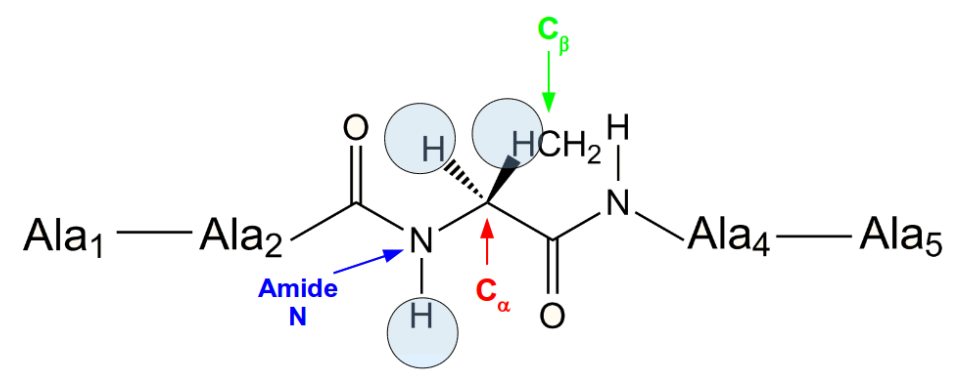

Figure 18. A schematic representation of the A5 peptide and the position of the hydrogen atoms before abstraction.

\subsubsection{The A5 Pentapeptide}

The extended conformation of the A5 peptide was conserved during the optimizations at both levels of theory and in both the gas phase and the simulated aqueous environment. A list of geometric parameters can be found in Table 10 and Table 11. The $\phi$ and $\psi$ angles were approximately $-155^{\circ}$ and $160^{\circ}$, respectively, causing the peptide to appear 'pleated', as shown in Figure 16. This peptide was not as extended as the G5 peptide was. This structure was stabilized with hydrogen bonds between the amide nitrogen and carbonyl oxygen of neighboring residues.

The hydrogen bonds between " $i$ " and " $i+2$ " residues of the A $5_{\text {HEL }}$ peptide remained 
intact during the optimizations at both levels of theory and in both environments, thus conserving the structure of the $3_{10}$ helix.

The structural perturbations resulting from $\mathrm{H}$-Abstraction from the $\mathrm{Ca}$ and amide nitrogen of residue 3 in A5 will be described in the subsequent sections.

\subsubsection{The Effect of H-Abstraction from the $C_{\alpha}$ of $A 5$}

The removal of the hydrogen atom from the $\mathrm{C}_{\alpha}$ decreased the length of the bonds between the $\mathrm{C}_{\alpha}$ and the amide nitrogen, methyl carbon $\left(\mathrm{C}_{\beta}\right)$ and carbonyl carbon atoms in the
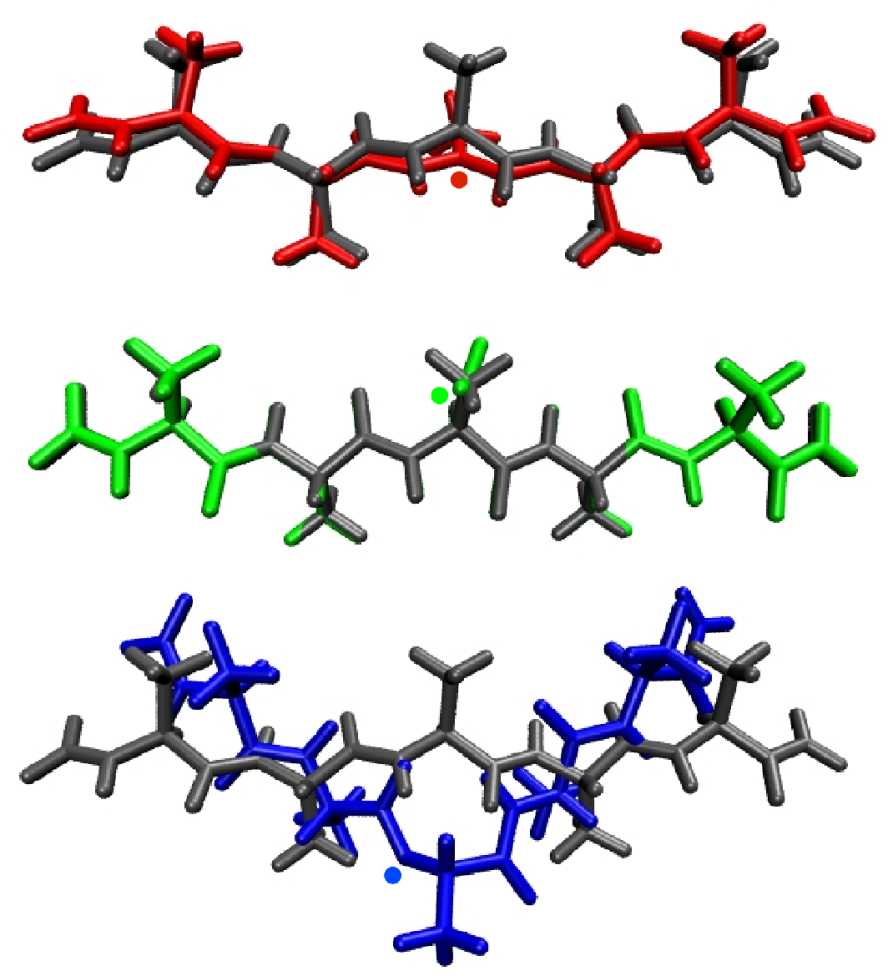

Figure 19. Structural alignment of the $A 5$ peptide and the $A 5$ peptide radicals in the extended conformation. The structures were obtained at the B3LYP/6-311+G(d,p) level of theory in the gas phase. The alignment of $\mathrm{A} 5\left(\mathrm{C}_{\alpha}{ }^{\circ}\right)$ peptide is shown in red (top), that of $\mathrm{A} 5\left(\mathrm{Me} \mathrm{e}^{\circ}\right)$ is shown in green (middle) and that of $\mathrm{A} 5\left(\mathrm{~N}^{*}\right)$ is shown in blue (bottom), whereas the A5 peptide is shown in gray. The RMSD of the structural alignments can be found in Table 11.

gas phase by $0.074 \AA, 0.049 \AA$ and $0.072 \AA$, respectively (Table 10). The observed decrease 
in bond length was slightly less pronounced when the $6-31 \mathrm{G}(\mathrm{d})$ basis set was used. The length of the amide bond between $\mathrm{Ala}^{3}$ and $\mathrm{Ala}^{2}$ increased by $0.020 \AA$, whereas the length of the bond between $\mathrm{Ala}^{3}$ and $\mathrm{Ala}^{4}$ increased by $0.012 \AA$. The respective amide bonds increased by $0.024 \AA$ and $0.013 \AA$ when the structures were optimized in the implicit solvent.

The pleats in the A5 peptide in the extended conformation can be shown in Figure 19, and is also characterized by $\phi$ and $\psi$ angles of $-157.42^{\circ}$ and $164.65^{\circ}$. The removal of the hydrogen atom from the $\mathrm{C}_{\alpha}$ caused the dihedral angles to become more planar, with $\phi$ and $\psi$ angles of $177.66^{\circ}$ and $-177.89^{\circ}$, respectively. The increased planarity was observed only at

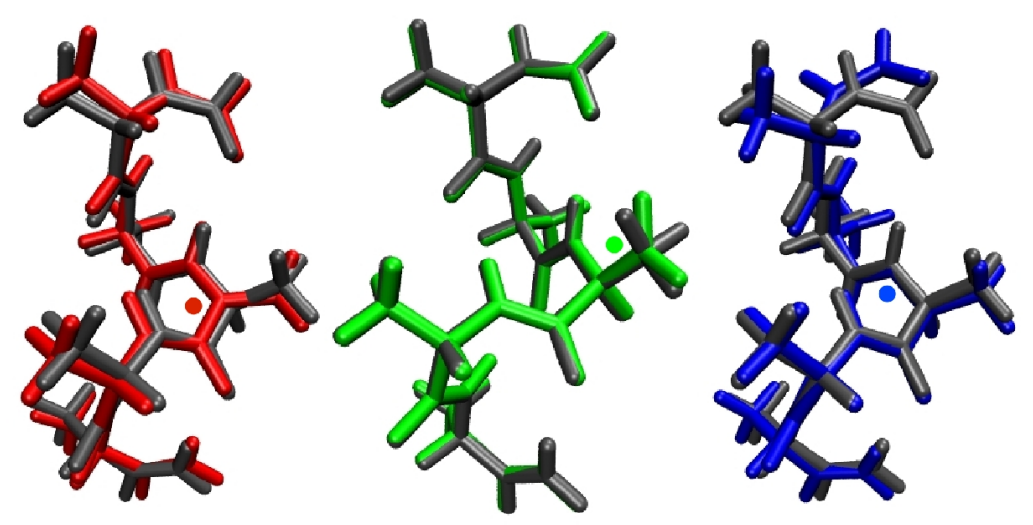

Figure 20. Structural alignment of the A5 peptide and the A5 peptide radicals in the helical conformation. The structures were obtained at the B3LYP/6-311+G(d,p) level of theory in the gas phase. The alignment of $\mathrm{A} 5\left(\mathrm{C}_{\alpha}{ }^{\circ}\right)$ peptide is shown in red (left), that of $\mathrm{A} 5\left(\mathrm{Me} \mathrm{e}^{\circ}\right)$ is shown in green (middle) and that of $\mathrm{A} 5\left(\mathrm{~N}^{*}\right)$ is shown in blue (right), whereas the A5 peptide is shown in gray. The RMSD of the structural alignments can be found in Table 11.

the $\mathrm{Ala}^{3}$ of the $\mathrm{A} 5\left(\mathrm{C}_{\alpha}\right)$ peptide, whereas the remaining residues retained the pleats shown in the A5 peptide. The intra-residue hydrogen bond between the amide nitrogen and the carbonyl oxygen decreased by $0.083 \AA$ when the $6-311+\mathrm{G}(\mathrm{d}, \mathrm{p})$ basis set was used, which is $0.057 \AA$ more than what was computed with the $6-31 \mathrm{G}(\mathrm{d})$ basis set. The RMSD of the 
peptide backbone containing the $\mathrm{C}_{\alpha}$ radical from that of the $\mathrm{A} 5$ peptide was $0.781 \AA$ in the gas phase, and $1.04 \AA$ in the implicit solvent. These results are shown in Table 11.

Similar to what was shown in the extended conformation, hydrogen atom abstraction from the $\mathrm{C}_{\alpha}$ of $\mathrm{Ala}^{3}$ increased the length of the bond between the $\mathrm{C}_{\alpha}$ and the amide nitrogen, $\mathrm{C}_{\beta}$ and carbonyl carbon atoms in the helical conformation, as shown in Figure 15. The length of these bonds decreased by $0.062 \AA, 0.042 \AA$ and $0.073 \AA$, respectively. The length of the amide bond between $\mathrm{Ala}^{2}$ and $\mathrm{Ala}^{3}$ increased by $0.019 \AA$, whereas the length of the amide bond between $\mathrm{Ala}^{3}$ and $\mathrm{Ala}^{4}$ increased by $0.013 \AA$. The respective amide bond lengths increased by $0.021 \AA$ and $0.015 \AA$ in the implicit solvent. Hydrogen abstraction from the $\mathrm{C}_{\alpha}$ in the helical conformation caused the $\phi$ dihedral angle to adopt a conformation that is moreplanar, as indicated by the $\phi$ angle changing from of $-157.42^{\circ}$ to $177.66^{\circ}$, however, the change in the $\psi$ angle was negligible. This data is presented in Table 11. The hydrogen bond between the amide nitrogen of $\mathrm{Ala}^{3}$ and carbonyl carbon of $\mathrm{Ala}^{1}$ decreased by $0.033 \AA$, whereas the hydrogen bond between the carbonyl carbon of $\mathrm{Ala}^{3}$ and the amide nitrogen of $\mathrm{Ala}^{5}$ decreased by $0.013 \AA$. Changes in dihedral angles suggest that there is a stronger coupling between $\mathrm{C}_{\alpha}$ and the amide nitrogen than between the $\mathrm{C}_{\alpha}$ and the carbonyl carbon. The RMSD of the $\mathrm{C}_{\alpha}$ peptide radical backbone from the backbone of the A5 peptide was $0.781 \AA$ and $1.04 \AA$, respectively. This data is shown in Table 11.

\subsubsection{The Effect of $\mathrm{H}$-Abstraction from the $\mathrm{C}_{\beta}$ of $\mathrm{Ala}^{3}$}

Hydrogen abstraction from the methyl group of A5 in the extended conformation caused increased the length of the bond between $C_{\beta}$ and $C_{\alpha}$ by $0.045 \AA$ This bond decreased by 
$0.042 \AA$ in the helical conformation as shown in Table 10. The remaining bond lengths in Ala ${ }^{3}$ changed by less than $0.003 \AA$ in both conformations. Moreover, the length of the amide bond between $\mathrm{Ala}^{2}$ and $\mathrm{Ala}^{3}$ decreased by only $0.001 \AA$, whereas the length of the bond between $\mathrm{Ala}^{3}$ and $\mathrm{Ala}^{4}$ decreased by $0.002 \AA$, with a negligible change shown to the respective bond lengths in optimized in the implicit solvent. The decrease in the intraresidue hydrogen bond distance compared to the extended and helical A5 was also negligible. Also, the $\phi$ and $\psi$ dihedral angles of the extended and helical A5( $\left.\mathrm{N}^{\circ}\right)$ deviated from the respective native A5 peptide by less than $5^{\circ}$ and the RMSD from the backbone of

Table 11. The $\phi$ and $\psi$ dihedral angles and H-bond distances of $\mathrm{Ala}^{3}$ in $\mathrm{A} 5$ and the peptide radicals in the extended and helical conformations. The geometric parameters were computed at the B3LYP/6-31G(d) and B3LYP/6-311+G(d,p) (shown in parentheses) levels of theory, both and in the gas phase and implicit solvent. The RMSD of the backbone atoms for the peptide radicals compared to those of A5 are also shown.

\begin{tabular}{ccccccc}
\hline \multirow{2}{*}{ Peptide } & Environment & \multicolumn{2}{c}{ Dihedral Angle } & \multicolumn{2}{c}{ Hydrogen bond length } & Backbone \\
\cline { 3 - 6 } & & $\phi /$ degrees & $\psi /$ degrees & Amide N & Carbonyl C & RMSD / \\
\hline $\mathrm{A}_{\text {Ext }}$ & Gaseous & $-160.0(-157.4)$ & $167.3(164.6)$ & $2.10(2.11)$ & $2.10(2.11)$ & $0.00(0.00)$ \\
& Aqueous & $-158.5(-152.5)$ & $162.1(157.4)$ & $2.14(2.22)$ & $2.14(2.22)$ & $0.00(0.00)$ \\
$\left.\mathrm{A}\left(\mathrm{C}_{\alpha}\right)^{\circ}\right)_{\text {Ext }}$ & Gaseous & $-178.7(177.6)$ & $-179.5(-177.8)$ & $2.02(2.03)$ & $2.02(2.03)$ & $0.673(0.781)$ \\
& Aqueous & $178.1(172.9)$ & $178.9(-177.2)$ & $2.04(2.06)$ & $2.04(2.06)$ & $0.854(1.04)$ \\
$\mathrm{A}\left({ }^{\circ} \mathrm{CH}_{3}\right)_{\text {Ext }}$ & Gaseous & $-164.4(-160.6)$ & $-163.1(171.5)$ & $2.06(2.10)$ & $2.06(2.10)$ & $0.0623(0.168)$ \\
& Aqueous & $-163.1(-159.0)$ & $169.2(161.0)$ & $2.10(2.17)$ & $2.10(2.17)$ & $0.192(0.143)$ \\
$\mathrm{A}\left(\mathrm{N}^{*}\right)_{\text {Ext }}$ & Gaseous & $-98.2(-98.6)$ & $66.0(72.6)$ & - & - & $2.72(2.53)$ \\
& Aqueous & $-100.7(-102.5)$ & $67.0(69.1)$ & - & - & $2.59(2.43)$ \\
$\mathrm{A}_{\text {Hel }}$ & Gaseous & $-63.2(-64.6)$ & $-19.9(-18.4)$ & $2.10(2.18)$ & $2.15(2.17)$ & $0.00(0.00)$ \\
& Aqueous & $-61.1(-63.2)$ & $-24.3(-20.9)$ & $2.06(2.17)$ & $2.08(2.11)$ & $0.00(0.00)$ \\
$\left.\mathrm{A}\left(\mathrm{C}_{\alpha}\right)^{*}\right)_{\text {Hel }}$ & Gaseous & $-45.5(-45.9)$ & $-21.6(-22.4)$ & $2.07(2.12)$ & $2.13(2.17)$ & $0.352(0.345)$ \\
& Aqueous & $-45.0(-45.6)$ & $-22.0(-22.7)$ & $2.03(2.12)$ & $2.04(2.08)$ & $0.421(0.346)$ \\
$\mathrm{A}\left({ }^{\circ} \mathrm{CH}_{3}\right)_{\text {Hel }}$ & Gaseous & $-61.3(-62.2)$ & $-24.4(-22.5)$ & $2.11(2.17)$ & $2.19(2.21)$ & $0.097(0.066)$ \\
& Aqueous & $-59.7(-60.8)$ & $-26.8(-24.3)$ & $2.06(2.15)$ & $2.08(2.12)$ & $0.054(0.032)$ \\
$\mathrm{A}\left(\mathrm{N}^{*}\right)_{\text {Hel }}$ & Gaseous & $-80.1(-81.4)$ & $-11.3(-12.5)$ & - & $2.26(2.30)$ & $0.64(0.524)$ \\
& Aqueous & $-81.5(-86.0)$ & $-13.6(-22.9)$ & - & $2.17(2.15)$ & $0.65(1.25)$ \\
\hline
\end{tabular}


Table 10. Bond lengths in $\mathrm{Ala}^{3}$ of $\mathrm{A} 5, \mathrm{~A}\left(\mathrm{C}_{\alpha}{ }^{\circ}\right), \mathrm{A}\left({ }^{\circ} \mathrm{CH}_{3}\right)$ and $\mathrm{A}\left(\mathrm{N}^{*}\right)$ in the extended and helical conformations. The bond lengths were computed at the B3LYP/6-31G(d) and B3LYP/6-311+G(d,p) (shown in parentheses) levels of theory, both and in the gas phase and implicit solvent.

\begin{tabular}{ccccccccc}
\hline \multirow{2}{*}{ Peptide } & Environment & \multicolumn{7}{c}{ Bond Length $(\AA)$} \\
\cline { 3 - 8 } & "n -1 ” amide & $\mathrm{N}-\mathrm{C}_{\alpha}$ & $\mathrm{N}-\mathrm{H}$ & $\mathrm{C}_{\alpha}-\mathrm{C}_{\beta}$ & $\mathrm{C}_{\alpha}-\mathrm{C}$ & $\mathrm{C}=\mathrm{O}$ & "n +1 ” amide \\
\hline \multirow{2}{*}{$\mathrm{A}_{\text {Ext }}$} & Gaseous & $1.350(1.349)$ & $1.452(1.454)$ & $1.015(1.013)$ & $1.540(1.539)$ & $1.539(1.538)$ & $1.232(1.227)$ & $1.350(1.349)$ \\
& Aqueous & $1.345(1.344)$ & $1.455(1.457)$ & $1.015(1.013)$ & $1.540(1.539)$ & $1.538(1.536)$ & $1.236(1.232)$ & $1.345(1.344)$ \\
$\mathrm{A}\left(\mathrm{C}_{\alpha}\right)_{\text {Ext }}$ & Gaseous & $1.370(1.369)$ & $1.379(1.380)$ & $1.023(1.020)$ & $1.494(1.490)$ & $1.467(1.466)$ & $1.247(1.243)$ & $1.361(1.361)$ \\
& Aqueous & $1.369(1.344)$ & $1.379(1.380)$ & $1.022(1.019)$ & $1.494(1.490)$ & $1.467(1.465)$ & $1.251(1.248)$ & $1.357(1.357)$ \\
$\mathrm{A}\left(\mathrm{CH}_{2}\right)_{\text {Ext }}$ & Gaseous & $1.352(1.351)$ & $1.459(1.457)$ & $1.016(1.014)$ & $1.459(1.494)$ & $1.558(1.558)$ & $1.231(1.225)$ & $1.347(1.347)$ \\
& Aqueous & $1.347(1.345)$ & $1.456(1.457)$ & $1.016(1.013)$ & $1.496(1.495)$ & $1.558(1.556)$ & $1.234(1.229)$ & $1.344(1.342)$ \\
$\mathrm{A}\left(\mathrm{N}^{*}\right)_{\text {Ext }}$ & Gaseous & $1.371(1.371)$ & $1.434(1.432)$ & - & $1.529(1.529)$ & $1.593(1.593)$ & $1.222(1.216)$ & $1.345(1.345)$ \\
& Aqueous & $1.372(1.371)$ & $1.439(1.440)$ & - & $1.530(1.530)$ & $1.585(1.581)$ & $1.226(1.223)$ & $1.343(1.342)$ \\
$\mathrm{A}_{\text {Hel }}$ & Gaseous & $1.354(1.353)$ & $1.460(1.461)$ & $1.016(1.014)$ & $1.531(1.530)$ & $1.543(1.541)$ & $1.232(1.227)$ & $1.354(1.353)$ \\
& Aqueous & $1.350(1.349)$ & $1.458(1.459)$ & $1.019(1.016)$ & $1.533(1.531)$ & $1.539(1.538)$ & $1.239(1.235)$ & $1.351(1.348)$ \\
$\mathrm{A}\left(\mathrm{C}_{\alpha}{ }^{\circ}\right)_{\text {Hel }}$ & Gaseous & $1.373(1.372)$ & $1.400(1.399)$ & $1.020(1.018)$ & $1.490(1.488)$ & $1.470(1.468)$ & $1.242(1.237)$ & $1.367(1.366)$ \\
& Aqueous & $1.371(1.370)$ & $1.395(1.395)$ & $1.022(1.020)$ & $1.490(1.488)$ & $1.465(1.463)$ & $1.250(1.246)$ & $1.364(1.363)$ \\
$\mathrm{A}\left(\mathrm{CH}_{2}\right)_{\text {Hel }}$ & Gaseous & $1.353(1.352)$ & $1.458(1.459)$ & $1.015(1.013)$ & $1.489(1.488)$ & $1.562(1.561)$ & $1.229(1.224)$ & $1.353(1.351)$ \\
& Aqueous & $1.350(1.349)$ & $1.456(1.456)$ & $1.018(1.016)$ & $1.491(1.489)$ & $1.557(1.489)$ & $1.236(1.232)$ & $1.350(1.347)$ \\
$\mathrm{A}\left(\mathrm{N}^{*}\right)_{\text {Hel }}$ & Gaseous & $1.377(1.372)$ & $1.421(1.419)$ & - & $1.534(1.534)$ & $1.589(1.588)$ & $1.225(1.219)$ & $1.342(1.342)$ \\
& Aqueous & $1.380(1.374)$ & $1.427(1.438)$ & - & $1.535(1.538)$ & $1.574(1.558)$ & $1.231(1.226)$ & $1.344(1.344)$ \\
\hline
\end{tabular}<smiles>[R][C@]1(C)CC[C@]([2H])(C(=O)NC)C1=O</smiles> 
A5 was only $0.168 \AA$.

\subsubsection{The Effect of H-Abstraction from the Amide Nitrogen of $\mathrm{Ala}^{3}$}

The removal of the hydrogen atom from the amide nitrogen caused the length of the bond between the amide $\mathrm{N}$ and the $\mathrm{C}_{\alpha}$ to decrease by $0.022 \AA$, whereas the subsequent bond between the $\mathrm{C}_{\alpha}$ and the carbonyl carbon increased by $0.055 \AA$. In the helical $\mathrm{A} 5\left(\mathrm{~N}^{*}\right)$ the decrease in the $\mathrm{N}-\mathrm{C}_{\alpha}$ bond length was $0.042 \AA$ and the increase in the $\mathrm{C}_{\alpha}-\mathrm{C}=\mathrm{O}$ bond length was $0.047 \AA$. In both conformations the length of the amide bonds between $\mathrm{Ala}^{3}$ and $\mathrm{Ala}^{2}$ and those between $\mathrm{Ala}^{3}$ and $\mathrm{Ala}^{4}$ increased. The length of the amide bond between $\mathrm{Ala}^{3}$ and $\mathrm{Ala}^{2}$ increased by $0.022 \AA$ in the extended conformation and $0.019 \AA$ in the helical, whereas the change in the length of the amide bond between $\mathrm{Ala}^{3}$ and $\mathrm{Ala}^{4}$ was negligible.

In the extended structure, the absence of the $\mathrm{H}$ atom prevented the formation of the intra-residue hydrogen bond; however, a hydrogen bond was formed between the carbonyl oxygen of $\mathrm{Ala}^{2}$ and the amide nitrogen of $\mathrm{Ala}^{4}$. It is suspected that this contributed to the roughly $60^{\circ}$ difference between the $\phi$ and $\psi$ angles of the native A5 peptide in the extended conformation and those of the extended $\mathrm{A} 5\left(\mathrm{~N}^{*}\right)$. In the helical $\mathrm{A} 5\left(\mathrm{~N}^{*}\right), \mathrm{H}$ abstraction from the amide nitrogen cleaved the hydrogen bond with the carbonyl carbon of Ala ${ }^{1}$. The loss of the hydrogen bond resulted in a decrease in the $\phi$ angle by $20^{\circ}$. The $\psi$ angle, deviated by less than $10^{\circ}$. The large perturbations in structure also appears in the RMSD value, which showed a deviation of $2.72 \AA$ from the backbone of the A5 peptide.

\subsection{Thermodynamic Analysis of the Pentapeptides}


The $\Delta \mathrm{G}^{0}, \Delta \mathrm{H}^{0}$ and $\Delta \mathrm{S}^{0}$ calculated for the H-abstraction from G5 and A5 by the ROS and the subsequent unfolding are described in the subsequent sections.

\subsubsection{H-Abstraction from G5.}

Gas phase results at the $6-311+\mathrm{G}(\mathrm{d}, \mathrm{p})$ basis set shows that the strength of the $\mathrm{C}_{\alpha}-\mathrm{H}$ bond is less than that of the N-H bond of the amide group, as shown in Table 12. Hydrogen abstraction from the $\mathrm{C}_{\alpha}$ whilst the peptide is in the extended conformation needs $109.6 \mathrm{~kJ}$ $\mathrm{mol}^{-1}$ less energy than that released from the amide nitrogen in the same conformation. The difference between $\mathrm{BDE}$ of the $\mathrm{C}_{\alpha}-\mathrm{H}$ bond and that of the $\mathrm{N}-\mathrm{H}$ bond in the helical conformation is $86.1 \mathrm{~kJ} \mathrm{~mol}^{-1}$. The BDE values of the $\mathrm{C}_{\alpha}-\mathrm{H}$ and $\mathrm{N}-\mathrm{H}$ bonds showed a conformational dependence, as shown by the lower BDE of the peptide in the helical conformation. Hydrogen abstraction from the $\mathrm{C}_{\alpha}$ requires $28.4 \mathrm{~kJ} \mathrm{~mol}^{-1}$ less energy in the extended conformation than in the helical conformation, whereas hydrogen abstraction from the amide nitrogen required $4.9 \mathrm{~kJ} / \mathrm{mol}$ less energy in the extended conformation.

The results obtained in the implicit solvent are within $1 \%$ of those obtained in the gas phase. The greatest deviation between the results obtained with the 6-31G(d) basis set and those obtained with the $6-311+\mathrm{G}(\mathrm{d}, \mathrm{p})$ basis set was shown in the helical $\mathrm{G} 5\left(\mathrm{C}_{\alpha}{ }^{\circ}\right)$ peptide computed in the gas phase and the $\mathrm{G} 5\left(\mathrm{~N}^{*}\right)$ peptide in the extended conformation, which had deviations of less than $3 \%$.

The bond dissociation energy energy can act as a measure of the relative stability of the peptide radicals since both of the peptides are derived from the same reactant and have the 
same co-product, an infinitely separated hydrogen atom. Therefore, the results in the gas phase with the $6-311+\mathrm{G}(\mathrm{d}, \mathrm{p})$ basis set indicate that $\mathrm{G} 5\left(\mathrm{C}_{\alpha}{ }^{\circ}\right)$ is $109.6 \mathrm{~kJ} \mathrm{~mol}^{-1}$ more stable than G5 $\left(\mathrm{N}^{*}\right)$. The relative stabilities computed in the implicit solvent model are within $1 \%$ of the gas phase values, and a similar deviation was observed between the two basis sets. When in a helix, $\mathrm{G} 5\left(\mathrm{C}_{\alpha}{ }^{\circ}\right)$ is $86.1 \mathrm{~kJ} \mathrm{~mol}^{-1}$ more stable than $\mathrm{G} 5\left(\mathrm{~N}^{*}\right)$. The deviations from the relative stability values in $\mathrm{G} 5_{\text {Ext }}$ were negligible when the implicit solvent and the smaller basis set was used.

Table 12. Reactions of ${ }^{\circ} \mathrm{OH}, \mathrm{HO}_{2}{ }^{\circ}$ and $\mathrm{O}_{2}{ }^{-\cdot}$ with $\mathrm{G} 5$ in the helical and extended conformations. The bond dissociation energy and helical to extended unfolding are computed at the B3LYP/6-31G(d) and B3LYP/6$311+\mathrm{G}(\mathrm{d}, \mathrm{p})$ (in parenthesis).

\begin{tabular}{ccccccc}
\hline Peptide & Environment & \multicolumn{2}{c}{$\begin{array}{c}\text { Bond Dissociation Energy } \\
\text { / } \mathrm{kJ} \mathrm{mol}^{-1}\end{array}$} & \multicolumn{3}{c}{ Transition from Helical to Extended } \\
\cline { 3 - 7 } & & Extended & Helix & $\begin{array}{c}\Delta \mathrm{H}^{\circ} / \\
\mathrm{kJ} \mathrm{mol}^{-1}\end{array}$ & $\begin{array}{c}\Delta \mathrm{G}^{\circ} / \\
\mathrm{kJ} \mathrm{mol}^{-1}\end{array}$ & $\begin{array}{c}\Delta \mathrm{S}^{\circ} / \\
\mathrm{J} \mathrm{mol}^{-1} \mathrm{~K}^{-1}\end{array}$ \\
\hline $\mathrm{G} 5$ & Gaseous & - & - & $3.3(-3.6)$ & $-32.7(-36.2)$ & $62.8(109.2)$ \\
& Aqueous & - & - & $20.8(10.4)$ & $-12.4(-20.5)$ & $111.6(104.2)$ \\
$\mathrm{G5}\left(\mathrm{C}_{\alpha}{ }^{*}\right)$ & Gaseous & $370.7(368.6)$ & $411.6(397.0)$ & $-36.0(-31.8)$ & $-64.8(-55.7)$ & $48.1(80.2)$ \\
& Aqueous & $370.9(368.8)$ & $409.2(407.3)$ & $-15.7(-26.1)$ & $-44.6(-52.7)$ & $97.0(89.1)$ \\
$\mathrm{G} 5\left(\mathrm{~N}^{*}\right)$ & Gaseous & $465.6(478.2)$ & $474.4(483.1)$ & $-3.4(-6.3)$ & $-26.5(-30.3)$ & $65.0(80.5)$ \\
& Aqueous & $469.7(482.4)$ & $484.4(489.7)$ & $8.2(5.3)$ & $-13.6(-16.2)$ & $73.6(72.3)$ \\
\hline
\end{tabular}

\subsubsection{Unfolding of $\mathrm{G5}_{\mathrm{HEL}}$}

The change in standard free energy $\left(\Delta \mathrm{G}^{\circ}\right)$ calculated with the $6-311+\mathrm{G}(\mathrm{d}, \mathrm{p})$ basis set are all negative when computed in the gas phase, and the corresponding gain in entropy under these conditions indicates that the helical unfolding is mainly entropy-driven. The $\Delta \mathrm{G}^{\circ}$ values were also negative for the calculations done in implicit solvent and those computed with the 6-31G(d) basis set, and these results can be found in Table 12. The difference in the 
$\Delta \mathrm{G}^{\mathrm{o}}$ measured in the gas phase with the $6-311+\mathrm{G}(\mathrm{d}, \mathrm{p})$ basis set indicates that the unfolding of $\mathrm{G} 5\left(\mathrm{~N}^{\cdot}\right)$ is $5.9 \mathrm{~kJ} \mathrm{~mol}^{-1}$ less favorable than the unfolding of G5. However, calculations in the same conditions indicate that the unfolding of $\mathrm{G} 5\left(\mathrm{C}_{\alpha}{ }^{\circ}\right)$ is more favorable than the unfolding of $\mathrm{G} 5$ by $-19.5 \mathrm{~kJ} \mathrm{~mol}^{-1}$. The unfolding of $\mathrm{G} 5\left(\mathrm{C}_{\alpha}{ }^{*}\right)$ is $28.2 \mathrm{~kJ} \mathrm{~mol}^{-1}$ more exothermic than the unfolding of G5 and $25.5 \mathrm{~kJ} \mathrm{~mol}^{-1}$ more exothermic than the unfolding of $\mathrm{G5}\left(\mathrm{N}^{*}\right)$, which suggests that increased tendency of $\mathrm{G5}\left(\mathrm{C}_{\alpha}{ }^{\circ}\right)$ to unfold is enthalpy-driven. Moreover, the unfolding of $\mathrm{G} 5\left(\mathrm{C}_{\alpha}{ }^{\circ}\right)$ and $\mathrm{G} 5\left(\mathrm{~N}^{\circ}\right)$ produced less entropy than the unfolding of G5, by $29.0 \mathrm{~J} \mathrm{~mol}^{-1} \mathrm{~K}^{-1}$ and $28.7 \mathrm{~J} \mathrm{~mol}^{-1} \mathrm{~K}^{-1}$, respectively. The unfolding of each peptide is more favorable in the implicit solvent than in the gas phase.

\subsubsection{Reactions of G5 with Reactive Oxygen Species}

The change in free energy computed in the gas phase with the $6-311+G(d, p)$ basis set showed that only the reass entropy than the unfolding of G5, by $29.0 \mathrm{~J}$ ctions involving the ${ }^{\circ} \mathrm{OH}$ radical and the G5 extended peptide are exergonic. These results can be found in Table

13. Reactions with the ${ }^{\bullet} \mathrm{OH}$ radical at the $\mathrm{C}_{\alpha}$ of $\mathrm{G} 5$ in the gas phase releases $141.5 \mathrm{~kJ} \mathrm{~mol}^{-1}$ of free energy. The reactions with the $\mathrm{HO}_{2}{ }^{\bullet}$ and $\mathrm{O}_{2}{ }^{-\bullet}$ radicals at the $\mathrm{C}_{\alpha}$ are both endergonic, and require $28.8 \mathrm{~kJ} \mathrm{~mol}^{-1}$ and $81.6 \mathrm{~kJ} \mathrm{~mol}^{-1}$, respectively, to proceed. These results were qualitatively similar to those computed with G5 in the helical conformation, however hydrogen abstraction from helical $\mathrm{G} 5_{\mathrm{Hel}}$ was less favorable. The $\Delta \mathrm{G}^{\circ}$ with ${ }^{\circ} \mathrm{OH}$ released only $122.0 \mathrm{~kJ} \mathrm{~mol}^{-1}$, whereas the reaction with $\mathrm{HO}_{2}{ }^{-}$requires $48.3 \mathrm{~kJ} \mathrm{~mol}^{-1}$ to proceed and that of the $\mathrm{O}_{2}^{-\bullet}$ requires an influx of $101.1 \mathrm{~kJ} \mathrm{~mol}^{-1}$ into the system. The relative reactivity of the 
ROS observed at the amide nitrogen are similar to that observed at the $\mathrm{C}_{\alpha}$. However hydrogen abstraction from the amide nitrogen is less favorable. The reactions at the amide nitrogen were still exergonic, however the $\Delta \mathrm{G}^{\mathrm{o}}$ was only $-32.8 \mathrm{~kJ} \mathrm{~mol}^{-1}$. The $\Delta \mathrm{G}^{\mathrm{o}}$ of the reactions with the ${ }^{\circ} \mathrm{OH}$ radical at the $\mathrm{C}_{\alpha}$ released $108.7 \mathrm{~kJ} \mathrm{~mol}^{-1}$ more free energy than hydrogen abstraction from the amide nitrogen. Moreover, the relative propensity of $\mathrm{HO}_{2}{ }^{\circ}$ and $\mathrm{O}_{2}^{-\bullet}$ to abstract a hydrogen atom from the $\mathrm{C}_{\alpha}$ is similar to that of ${ }^{\bullet} \mathrm{OH}$.

The relative enthalpy of the ROS and that of each $\mathrm{H}$-abstraction reactions was similar to the trends observed for their free energy. The enthalpy change of the reaction with ${ }^{\circ} \mathrm{OH}$ at the $\mathrm{C}_{\alpha}$ in the gas phase using the $6-311+\mathrm{G}(\mathrm{d}, \mathrm{p})$ basis set was $-140.0 \mathrm{~kJ} \mathrm{~mol}^{-1}$, whereas the reaction with the $\mathrm{HO}_{2}{ }^{-}$and $\mathrm{O}_{2}{ }^{-\bullet}$ were both endothermic, requiring $27.2 \mathrm{~kJ} \mathrm{~mol}^{-1}$ and $86.3 \mathrm{~kJ}$ $\mathrm{mol}^{-1}$ of heat, respectively, to proceed. The enthalpy in the implicit solvent was within $10 \%$ of the gas phase values.

A gain in entropy contributed to the gas phase reaction of ${ }^{\bullet} \mathrm{OH}\left(4.8 \mathrm{~J} \mathrm{~mol}^{-1} \mathrm{~K}^{-1}\right)$ and $\mathrm{O}_{2}{ }^{\cdot}$ (15.6 $\mathrm{J} \mathrm{mol}^{-1} \mathrm{~K}^{-1}$ ) at the $\mathrm{C}_{\alpha}$ when $\mathrm{G} 5$ was in the extended conformation whereas entropy was lost in the reaction at the same site with $\mathrm{HO}_{2} \cdot\left(-5.4 \mathrm{~J} \mathrm{~mol}^{-1} \mathrm{~K}^{-1}\right)$. Entropy was lost during hydrogen abstraction from the $\mathrm{OH}\left(-1.7 \mathrm{~J} \mathrm{~mol}^{-1} \mathrm{~K}^{-1}\right), \mathrm{HO}_{2} \cdot\left(-12.0 \mathrm{~J}^{-1} \mathrm{~mol}^{-1} \mathrm{~K}^{-1}\right)$ during abstraction at the amide nitrogen, whereas $9.0 \mathrm{~J} \mathrm{~mol}^{-1} \mathrm{~K}^{-1}$ of entropy was gained when a hydrogen atom was abstracted by $\mathrm{O}_{2}{ }^{-}$. Hydrogen abstraction from the amide nitrogen of the helical G5 caused an increase in entropy for all three ROS.

\subsubsection{H-Abstraction from A5.}

Gas phase results at the $6-311+G(d, p)$ basis set shows that the strength of the $C_{\alpha}-H$ bond 
Table 13. The enthalpy, free energy and entropy of the reactions of ${ }^{\circ} \mathrm{OH}, \mathrm{HO}_{2}{ }^{\cdot}$ and $\mathrm{O}_{2}{ }^{\cdot}$ with $\mathrm{G} 5$, producing the $\mathrm{G}\left(\mathrm{C}_{\alpha}{ }^{*}\right)$ and $\mathrm{G}\left(\mathrm{N}^{*}\right)$ radicals in the helical and extended conformations. The values were computed in the gas phase and implicit solvent, at the B3LYP/6-31G(d) and B3LYP/6-311+G(d,p) (in parenthesis) levels of theory.

\begin{tabular}{|c|c|c|c|c|c|c|c|}
\hline \multirow{2}{*}{ Reactants } & \multirow{2}{*}{ Environment } & \multicolumn{2}{|c|}{$\Delta \mathrm{H}^{\mathrm{o}} / \mathrm{kJ} \mathrm{mol}^{-1}$} & \multicolumn{2}{|c|}{$\Delta \mathrm{G}^{\mathrm{o}} / \mathrm{kJ} \mathrm{mol}^{-1}$} & \multicolumn{2}{|c|}{$\Delta \mathrm{S}^{\mathrm{o}} / \mathrm{J} \mathrm{mol}^{-1} \mathrm{~K}^{-1}$} \\
\hline & & $\mathrm{C}_{\alpha}$ & $\mathrm{N}$ & $\mathrm{C}_{\alpha}$ & $\mathrm{N}$ & $\mathrm{C}_{\alpha}$ & $\mathrm{N}$ \\
\hline \multirow{2}{*}{$\cdot \mathrm{OH}+\mathrm{G} 5_{\mathrm{Ext}}$} & Gaseous & $-134.7(-140.0)$ & $-42.3(-33.3)$ & $-112.0(-141.5)$ & $-17.76(-32.8)$ & $-10.8(4.8)$ & $-17.1(-1.7)$ \\
\hline & Aqueous & $-121.5(-146.8)$ & $-25.4(-36.3)$ & $-120.9(-145.8)$ & $-23.60(-39.3)$ & $-2.1(-3.3)$ & $-6.2(10.1)$ \\
\hline \multirow{2}{*}{$\mathrm{HO}_{2}{ }^{-}+\mathrm{G} 5_{\mathrm{Ext}}$} & Gaseous & $19.7(27.2)$ & $112.1(133.9)$ & $58.3(28.8)$ & $152.59(137.5)$ & $-21.2(-5.4)$ & $-27.6(-12.0)$ \\
\hline & Aqueous & $36.1(10.8)$ & $132.2(121.3)$ & $39.9(14.9)$ & $137.28(121.3)$ & $-12.6(-13.6)$ & $-16.7(-0.2)$ \\
\hline \multirow{2}{*}{$\mathrm{O}_{2}^{-\bullet}+\mathrm{G} 5_{\mathrm{Ext}}$} & Gaseous & $87.2(86.3)$ & $179.6(193.0)$ & $87.3(81.6)$ & $181.62(190.3)$ & $-0.1(15.6)$ & $-6.4(9.0)$ \\
\hline & Aqueous & $89.0(87.8)$ & $185.1(198.3)$ & $86.5(85.6)$ & $183.86(192.1)$ & $8.4(7.3)$ & $4.3(20.7)$ \\
\hline \multirow{2}{*}{$\cdot \mathrm{OH}+\mathrm{G} 5_{\mathrm{Hel}}$} & Gaseous & $-95.4(-111.8)$ & $-35.6(-30.6)$ & $-79.9(-122.0)$ & $-24.03(-38.6)$ & $13.6(33.9)$ & $26.5(27.0)$ \\
\hline & Aqueous & $-85.0(-110.2)$ & $-12.8(-31.2)$ & $-88.7(-113.7)$ & $-22.37(-43.7)$ & $12.4(11.7)$ & 31.7 (41.9) \\
\hline \multirow{2}{*}{$\mathrm{HO}_{2}{ }^{-}+\mathrm{G}_{\mathrm{Hel}}$} & Gaseous & $59.1(55.3)$ & $118.8(136.6)$ & $90.3(48.3)$ & $146.33(131.6)$ & $3.2(23.5)$ & $16.0(16.6)$ \\
\hline & Aqueous & $72.7(47.4)$ & $144.8(126.4)$ & $72.1(47.0)$ & $138.50(117.0)$ & $1.9(1.3)$ & $21.2(31.6)$ \\
\hline \multirow{2}{*}{$\mathrm{O}_{2}^{-\cdot}+\mathrm{G} 5_{\mathrm{Hel}}$} & Gaseous & $126.6(114.4)$ & $186.4(195.7)$ & $119.3(101.1)$ & $175.36(184.4)$ & $24.3(44.6)$ & $37.1(37.7)$ \\
\hline & Aqueous & $125.5(124.4)$ & $197.7(203.4)$ & $118.6(117.8)$ & $185.08(187.7)$ & $23.0(22.3)$ & $42.3(52.6)$ \\
\hline
\end{tabular}


was less than that of the $\mathrm{C}_{\beta}-\mathrm{H}$ bond of the Ala side chain and that of the N-H bond of the amide group. As presented in Table 14, hydrogen abstraction from the $C_{\alpha}$ whilst the peptide is in the extended conformation requires $83.5 \mathrm{~kJ} \mathrm{~mol}^{-1}$ and $106.2 \mathrm{~kJ} \mathrm{~mol}^{-1}$ less energy than from $\mathrm{C}_{\beta}$ and the amide nitrogen, respectively. The difference between BDE of $\mathrm{C}_{\alpha}-\mathrm{H}$ bond and those of the $\mathrm{C}_{\beta}-\mathrm{H}$ and $\mathrm{N}-\mathrm{H}$ bonds in the helical conformation is $58.2 \mathrm{~kJ} \mathrm{~mol}^{-1}$ and $92.7 \mathrm{~kJ}$ mol $^{-1}$, respectively. The BDE values of the $\mathrm{C}_{\alpha}-\mathrm{H}$ and $\mathrm{N}-\mathrm{H}$ bonds showed a conformational dependence, as shown by the lower BDE of the peptide in the helical conformations.

Hydrogen abstraction from the $\mathrm{C}_{\alpha}$ required $23.4 \mathrm{~kJ} \mathrm{~mol}^{-1}$ less energy in the extended conformation than in the helical conformation, whereas hydrogen abstraction from the amide nitrogen required $9.9 \mathrm{~kJ} \mathrm{~mol}^{-1}$ less energy in the extended conformation. The results obtained in the implicit solvent are within $1 \%$ of those obtained in the gas phase. The greatest deviation between the results obtained with the 6-31G(d) basis set and those obtained with the $6-311+\mathrm{G}(\mathrm{d}, \mathrm{p})$ basis set was shown in the $\mathrm{A} 5\left(\mathrm{~N}^{*}\right)$ peptide, which had a deviation of less than $3 \%$.

The bond dissociation energy values can act as a measure of the relative peptide radical stability in this case as well. Therefore, the results in the gas phase with the $6-311+G(d, p)$ basis set indicate that $\mathrm{A} 5\left(\mathrm{C}_{\alpha}{ }^{\circ}\right)$ is $83.5 \mathrm{~kJ} \mathrm{~mol}^{-1}$ more stable than $\mathrm{A} 5\left(\mathrm{CH}_{2}{ }^{\circ}\right)$ and $106.2 \mathrm{~kJ} \mathrm{~mol}^{-1}$ more stable than $\mathrm{A} 5\left(\mathrm{~N}^{*}\right)$. The relative stabilities computed in the implicit solvent model are within $1 \%$ of the gas phase values, and a similar deviation was observed between the two basis sets. When in a helix, $\mathrm{A} 5\left(\mathrm{C}_{\alpha}{ }^{\circ}\right)$ is $58.2 \mathrm{~kJ} \mathrm{~mol}^{-1}$ more stable than $\mathrm{A} 5\left({ }^{\circ} \mathrm{CH}_{3}\right)$ and $92.7 \mathrm{~kJ}$ $\mathrm{mol}^{-1}$ more stable than $\mathrm{A} 5\left(\mathrm{~N}^{\cdot}\right)$. As shown in the extended the conformation, the deviations 
Table 14. Reactions of ${ }^{\circ} \mathrm{OH}, \mathrm{HO}_{2}{ }^{\circ}$ and $\mathrm{O}_{2}{ }^{-\bullet}$ with $\mathrm{A} 5$ in the helical and extended conformations. The free energy of $\mathrm{H}$ abstraction and helical to extended unfolding are computed at the B3LYP/6-31G(d) and B3LYP/6-311+G(d,p) (in parenthesis).

\begin{tabular}{ccccccc}
\hline Peptide & Environment & \multicolumn{2}{c}{$\begin{array}{c}\text { Bond Dissociation Energy } \\
/ \mathrm{kJ} \mathrm{mol}^{-1}\end{array}$} & \multicolumn{3}{c}{$\begin{array}{c}\text { Transition from Helical to } \\
\text { Extended Conformation }\end{array}$} \\
\cline { 3 - 7 } & & Extended & Helix & $\begin{array}{c}\Delta \mathrm{H}^{\mathrm{o}} \\
/ \mathrm{kJ} \mathrm{mol}^{-1}\end{array}$ & $\begin{array}{c}\Delta \mathrm{G}^{\circ} \\
/ \mathrm{kJ} \mathrm{mol}^{-1}\end{array}$ & $\begin{array}{c}\Delta \mathrm{S}^{\circ} \\
/ \mathrm{J} \mathrm{mol}^{-1} \mathrm{~K}^{-1}\end{array}$ \\
\hline $\mathrm{A} 5$ & Gaseous & - & - & $10.8(2.3)$ & $-7.8(-17.8)$ & $62.8(67.9)$ \\
& Aqueous & - & - & $29.5(15.2)$ & $9.0(-7.3)$ & $68.6(75.5)$ \\
$\mathrm{A} 5\left(\mathrm{C}_{\alpha}{ }^{\circ}\right)$ & Gaseous & $366.4(367.5)$ & $393.0(390.9)$ & $-13.4(-19.0)$ & $-27.7(-36.4)$ & $48.1(58.5)$ \\
& Aqueous & $369.2(370.4)$ & $390.0(387.6)$ & $9.2(0.0)$ & $-14.2(-18.4)$ & $78.8(61.6)$ \\
$\mathrm{A} 5\left({ }^{\circ} \mathrm{CH}_{3}\right)$ & Gaseous & $456.9(451.0)$ & $455.2(449.1)$ & $12.7(4.5)$ & $-6.6(-16.6)$ & $65.0(70.8)$ \\
& Aqueous & $455.6(449.3)$ & $455.6(450.1)$ & $29.1(14.4)$ & $8.5(-9.1)$ & $68.9(79.1)$ \\
$\mathrm{A} 5\left(\mathrm{~N}^{*}\right)$ & Gaseous & $461.4(473.7)$ & $475.9(483.6)$ & $-2.5(-6.4)$ & $-13.1(-19.7)$ & $35.6(44.7)$ \\
& Aqueous & $463.8(476.6)$ & $489.1(486.6)$ & $4.1(5.2)$ & $-8.9(-3.2)$ & $43.7(28.6)$ \\
\hline
\end{tabular}

from the relative stability values were negligible when the implicit solvent and the smaller basis set was used.

\subsubsection{Unfolding of $\mathrm{A5}_{\mathrm{HEL}}$}

The change in standard free energy $\left(\Delta \mathrm{G}^{\circ}\right)$, calculated with the $6-311+\mathrm{G}(\mathrm{d}, \mathrm{p})$ basis set are all negative when computed in the gas phase, and the corresponding gain in entropy under these conditions indicates that this conformational change is mainly entropy-driven. These results can be found in Table 14. The $\Delta \mathrm{G}^{\mathrm{o}}$ for the helix to extended conformational change of $\mathrm{A} 5\left(\mathrm{CH}_{2}{ }^{\circ}\right)$ and $\mathrm{A} 5\left(\mathrm{~N}^{\circ}\right)$ are similar to that of the A5 peptide, however, the unfolding of $\mathrm{A} 5\left(\mathrm{C}_{\alpha}{ }^{\circ}\right)$ is more favorable than the unfolding of A5 by $-18.6 \mathrm{~kJ} \mathrm{~mol}^{-1}$. The unfolding of $\mathrm{A} 5\left(\mathrm{C}_{\alpha}{ }^{*}\right)$ is $16.7 \mathrm{~kJ} \mathrm{~mol}^{-1}$ more exothermic than the unfolding of $\mathrm{A} 5$, which suggests that increased tendency of $A 5\left(C_{\alpha}{ }^{*}\right)$ to unfold is enthalpy-driven. The unfolding of $A 5\left(N^{*}\right)$ is 8.7 $\mathrm{kJ} \mathrm{mol}^{-1}$ more exothermic than the unfolding of the A5 peptide. Moreover, the unfolding of $\mathrm{A} 5\left(\mathrm{C}_{\alpha}{ }^{\circ}\right)$ and $\mathrm{A} 5\left(\mathrm{~N}^{\circ}\right)$ showed smaller increases in entropy than the unfolding of A5, by $9.4 \mathrm{~J}$ 
$\mathrm{mol}^{-1} \mathrm{~K}^{-1}$ and $23.2 \mathrm{~J} \mathrm{~mol}^{-1} \mathrm{~K}^{-1}$, respectively. The unfolding of each peptide was less favorable in the implicit solvent than the gas phase.

\subsubsection{Reactions of A5 with Reactive Oxygen Species}

The change in free energy computed in the gas phase with the $6-311+\mathrm{G}(\mathrm{d}, \mathrm{p})$ basis set showed that only the reactions involving the ${ }^{\circ} \mathrm{OH}$ radical and the $\mathrm{A} 5$ extended peptide were exergonic. These results can be found in Table 15. For reactions at the $\mathrm{C}_{\alpha}$ of $\mathrm{A} 5$ in the gas phase, the reactions involving the ${ }^{\circ} \mathrm{OH}$ radical released $167.2 \mathrm{~kJ} \mathrm{~mol}^{-1}$ more free energy than those with the $\mathrm{HO}_{2}{ }^{-}$radical and $226.3 \mathrm{~kJ} \mathrm{~mol}^{-1}$ more free energy than with the $\mathrm{O}_{2}^{-\bullet}$ radical. The reaction Gibbs free energy values indicate that the $C_{\alpha}$ is more susceptible than the $C_{\beta}$ and amide nitrogen to $\mathrm{H}$-abstraction by the ROS. The reaction of ${ }^{\circ} \mathrm{OH}$ with $\mathrm{A} 5$ at the $\mathrm{C}_{\alpha}$ released $79.3 \mathrm{~kJ} \mathrm{~mol}^{-1}$ more free energy than the abstraction from the $\mathrm{CH}_{3}$ and $102.4 \mathrm{~kJ} \mathrm{~mol}^{-1}$ more energy than the abstraction from the amide nitrogen. The $\Delta \mathrm{H}^{\mathrm{o}}$ values of the reactions with each of the ROS were similar to those of the $\Delta \mathrm{G}^{\mathrm{o}}$ values. The $\mathrm{H}$ abstraction reactions of each ROS in the gas phase gained entropy, irrespective of the location. Hydrogen abstraction from $\mathrm{C}_{\alpha}$ and the amide nitrogen showed a decrease of enthalpy in the implicit solvent, whereas the reactions with $\mathrm{O}_{2}^{-\bullet}$ radical showed the largest gain in entropy. Results in the gas phase with the $6-311+\mathrm{G}(\mathrm{d}, \mathrm{p})$ basis set showed that the reaction of the $\mathrm{O}_{2}^{-\bullet}$ radical at the $\mathrm{C}_{\alpha}$ of the $\mathrm{A} 5$ yielded $10.7 \mathrm{~J} \cdot \mathrm{mol}^{-1} \mathrm{~K}^{-1}$ and $21.1 \mathrm{~J} \cdot \mathrm{mol}^{-1} \mathrm{~K}^{-1}$ more entropy than the analogous reaction with ${ }^{\circ} \mathrm{OH}$ and $\mathrm{O}_{2}^{-{ }^{-}}$.

The order of the reactivity of the ROS with the helical A5 peptide was qualitatively similar to those with A5 in the extended conformation, however the $\Delta \mathrm{G}^{\mathrm{o}}$ of each reaction was 
Table 15. The enthalpy, free energy and entropy of the reactions of ${ }^{\circ} \mathrm{OH}, \mathrm{HO}_{2}{ }^{\cdot}$ and $\mathrm{O}_{2} \cdot{ }^{\cdot}$ with $\mathrm{A} 5$, producing the $\mathrm{A}\left(\mathrm{C}_{\alpha}{ }^{\circ}\right), \mathrm{A}\left({ }^{\circ} \mathrm{CH}_{3}\right)$ and $\mathrm{A}\left(\mathrm{N}^{*}\right)$ radicals in the helical and extended conformations. The values were computed in the gas phase and implicit solvent, at the B3LYP/6-31G(d) and B3LYP/6-311+G(d,p) (in parenthesis) levels of theory.

\begin{tabular}{|c|c|c|c|c|c|c|c|c|c|c|}
\hline \multirow{2}{*}{ Reactants } & \multirow{2}{*}{ Environment } & \multicolumn{3}{|c|}{$\Delta \mathrm{H}^{\circ} / \mathrm{kJ} \mathrm{mol}^{-1}$} & \multicolumn{3}{|c|}{$\Delta \mathrm{G}^{\circ} / \mathrm{kJ} \mathrm{mol}^{-1}$} & \multicolumn{3}{|c|}{$\Delta \mathrm{S}^{\mathrm{o}} / \mathrm{J} \mathrm{mol}^{-1} \mathrm{~K}^{-1}$} \\
\hline & & $\mathrm{C}_{\alpha}$ & $\mathrm{CH}_{3}$ & $\mathrm{~N}$ & $\mathrm{C}_{\alpha}$ & $\mathrm{CH}_{3}$ & $\mathrm{~N}$ & $\mathrm{C}_{\alpha}$ & $\cdot \mathrm{CH}_{3}$ & $\mathrm{~N}$ \\
\hline \multirow{2}{*}{$\cdot \mathrm{OH}+\mathrm{A} 5_{\mathrm{Ext}}$} & Gaseous & $-138.4(-140.9)$ & $-52.7(-61.6)$ & $-47.4(-38.5)$ & $-123.4(-145.8)$ & $-40.3(-69.1)$ & $-32.9(-44.2)$ & $14.9(16.6)$ & $23.6(25.1)$ & $16.8(19.2)$ \\
\hline & Aqueous & $-124.0(-145.0)$ & $-41.7(-70.7)$ & $-32.4(-42.4)$ & $-131.6(-145.3)$ & $-46.8(-76.4)$ & $-36.6(-42.4)$ & $25.6(0.9)$ & $17.2(19.3)$ & $14.0(0.1)$ \\
\hline \multirow{2}{*}{$\mathrm{HO}_{2}{ }^{\circ}+\mathrm{A} 5_{\mathrm{Ext}}$} & Gaseous & $16.0(26.3)$ & $101.7(105.6)$ & $107.0(128.7)$ & $46.9(24.4)$ & $130.0(101.2)$ & $137.4(126.0)$ & $4.4(6.2)$ & $13.1(14.8)$ & $6.3(8.9)$ \\
\hline & Aqueous & $33.7(12.6)$ & $116.0(87.0)$ & $125.2(115.2)$ & $29.2(15.4)$ & $114.0(84.3)$ & $124.2(118.3)$ & $15.1(-9.4)$ & $6.7(9.0)$ & $3.5(-10.2)$ \\
\hline \multirow{2}{*}{$\mathrm{O}_{2}^{-*}+\mathrm{A} 5_{\mathrm{Ext}}$} & Gaseous & $83.5(85.4)$ & $169.3(164.7)$ & $174.6(187.8)$ & $75.9(77.2)$ & $159.0(154.0)$ & $166.4(178.8)$ & $25.6(27.3)$ & $34.2(35.9)$ & $27.4(30.0)$ \\
\hline & Aqueous & 86.5 (89.6) & $168.8(164.0)$ & $178.1(192.3)$ & $75.7(86.2)$ & $160.5(155.0)$ & $170.7(189.0)$ & $36.2(11.5)$ & $27.8(30.0)$ & $24.5(10.7)$ \\
\hline \multirow{2}{*}{$\cdot \mathrm{OH}+\mathrm{A} 5_{\mathrm{Hel}}$} & Gaseous & $-114.2(-119.5)$ & $-54.6(-63.7)$ & $-34.0(-29.7)$ & $-103.5(-127.2)$ & $-41.5(-70.3)$ & $-27.6(-42.3)$ & $29.6(26.0)$ & $21.3(22.3)$ & $43.9(42.5)$ \\
\hline & Aqueous & $-103.7(-129.7)$ & $-41.3(-69.9)$ & $-7.0(-32.4)$ & $-108.3(-134.1)$ & $-46.3(-74.6)$ & $-18.6(-46.4)$ & $15.5(14.8)$ & $17.0(15.8)$ & $38.9(47.0)$ \\
\hline \multirow{2}{*}{$\mathrm{HO}_{2}{ }^{-}+\mathrm{A} 5_{\text {Hel }}$} & Gaseous & $40.3(47.7)$ & 99.8 (103.5) & $120.5(137.5)$ & $66.8(43.0)$ & 128.8 (99.9) & 142.7 (127.9) & $19.1(15.7)$ & $10.8(11.9)$ & $33.5(32.2)$ \\
\hline & Aqueous & $54.0(27.9)$ & 116.4 (87.7) & $150.6(125.2)$ & $52.5(26.5)$ & $114.5(86.1)$ & $142.1(114.3)$ & $5.0(4.4)$ & $6.5(5.4)$ & $28.4(36.6)$ \\
\hline \multirow{2}{*}{$\mathrm{O}_{2}{ }^{-\bullet}+\mathrm{A} 5_{\mathrm{Hel}}$} & Gaseous & $107.8(106.8)$ & $167.3(162.6)$ & $188.0(196.6)$ & 95.8 (95.8) & $157.8(152.7)$ & $171.7(180.7)$ & $40.2(36.8)$ & $32.0(33.0)$ & $54.6(53.2)$ \\
\hline & Aqueous & $106.8(104.9)$ & $169.3(164.7)$ & $203.5(202.2)$ & 99.1 (97.3) & $161.0(156.8)$ & $188.7(185.0)$ & $26.1(25.4)$ & $27.6(26.4)$ & $49.5(57.6)$ \\
\hline
\end{tabular}


slightly less favorable. Moreover, the relative ease at which a hydrogen atom can be abstracted from the of the $\mathrm{C}_{\alpha}, \mathrm{C}_{\beta}$ and the amide nitrogen was also similar to what was found in the extended conformation.

\subsection{Molecular Dynamic Simulations of Heptapeptides}

Analysis of the secondary structure elements showed that only $\gamma-, \beta$-, $\alpha$ - and $\pi$-turn structures were observed in the ALA and ALR peptides, whereas neither $\delta$ - nor inverse $\gamma$ turns were detected. These results are shown in Table 16.

Table 16. The number of turn structures identified in ALA and ALR, where $i$ is the residue number of the starting amino acid of the turn and $\mathrm{Hb}$ identifies the turn structures that were further stabilized by $\mathrm{H}$ bonds.

\begin{tabular}{|c|c|c|c|c|c|}
\hline \multirow{2}{*}{$\begin{array}{c}\text { Secondary Structure } \\
\text { Element }\end{array}$} & \multicolumn{2}{|c|}{ No. of Structures } & \multirow{2}{*}{$\begin{array}{c}\text { Secondary Structure } \\
\text { Element }\end{array}$} & \multicolumn{2}{|c|}{ No. of Structures } \\
\hline & ALA & ALR & & ALA & ALR \\
\hline$\gamma$-turn $(\mathrm{i}=3)$ & 1781 & 1273 & $\beta$-turn $(i=2)$ & 3858 & 1730 \\
\hline$\gamma$-turn $(\mathrm{i}=4)$ & 1493 & 7936 & $\beta$-turn $(\mathrm{Hb}, \mathrm{i}=2)$ & 1953 & 15 \\
\hline$\gamma$-turn $(i=5)$ & 2107 & 1366 & $\beta$-turn $(i=3)$ & 3356 & 2292 \\
\hline$\pi$-turn $(i=2)$ & 1266 & 3645 & $\beta$-turn $(\mathrm{Hb}, \mathrm{i}=3)$ & 1693 & 228 \\
\hline$\pi$-turn $(\mathrm{Hb}, \mathrm{i}=2)$ & 135 & 44 & $\beta$-turn $(\mathrm{i}=4)$ & 3323 & 1457 \\
\hline$\pi$-turn $(\mathrm{i}=3)$ & 1626 & 8050 & $\beta$-turn $(\mathrm{Hb}, \mathrm{i}=4)$ & 2277 & 8371 \\
\hline$\pi$-turn $(\mathrm{Hb}, \mathrm{i}=3)$ & 1 & 26 & $\beta$-turn $(i=5)$ & 3874 & 4519 \\
\hline- & - & - & $\beta$-turn $(\mathrm{Hb}, \mathrm{i}=5)$ & 1661 & 1074 \\
\hline
\end{tabular}

More than 4-times more $\gamma$-turns $(i=4), \beta$-turns $(\mathrm{Hb}, \mathrm{i}=4), \alpha$-turns $(i=2)$ and $\pi$-turns $(i=3)$ were observed in ALR than were observed in ALA, as shown in Table 16. The Alas residue was one of the two central residues, or the only central residue in each of these structures, indicating that the ALR residue increased the propensity of turn formation when in a central position. The distribution of the distances between $\mathrm{O}_{\mathrm{i}} \cdots \mathrm{N}_{\mathrm{i}+2}(\mathrm{i}=3,4$ and 5) was calculated for ALA and ALR, which corresponds to a $\gamma$-turn, and is shown in Figure 21. 
ALA

$\square \mathrm{d}(\mathrm{Ala} 3, \mathrm{O} \cdots \mathrm{Ala5}, \mathrm{N}) \square \mathrm{d}(\mathrm{Ala4}, \mathrm{O} \cdots \mathrm{Ala}$,N) $\square \mathrm{d}(\mathrm{Ala5}, \mathrm{O} \cdots \mathrm{Ala}$,N)

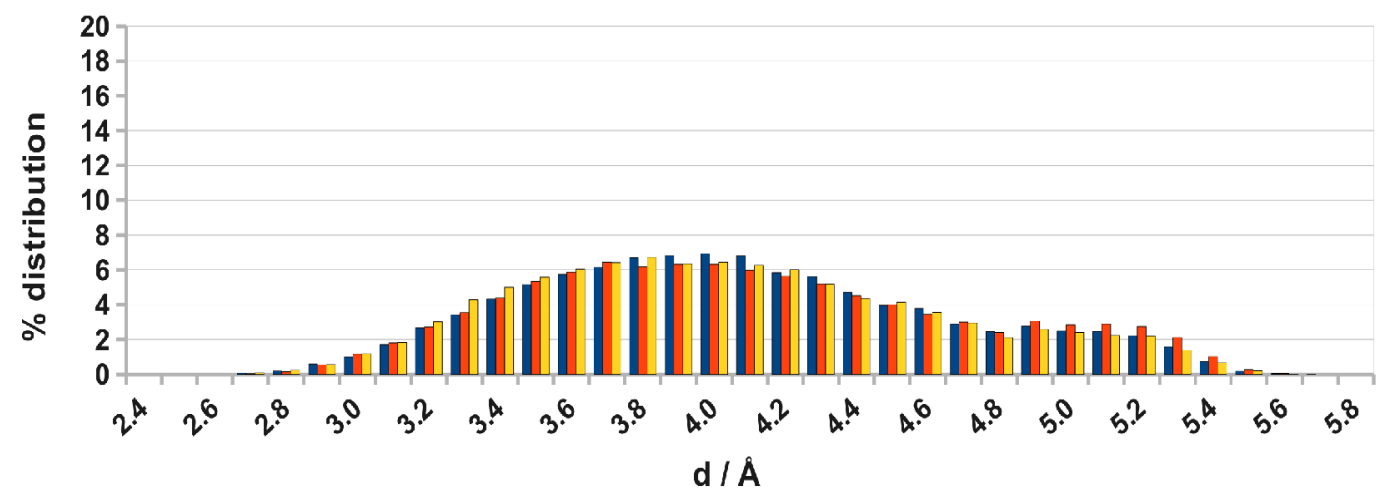

ALR

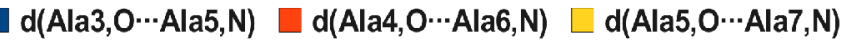

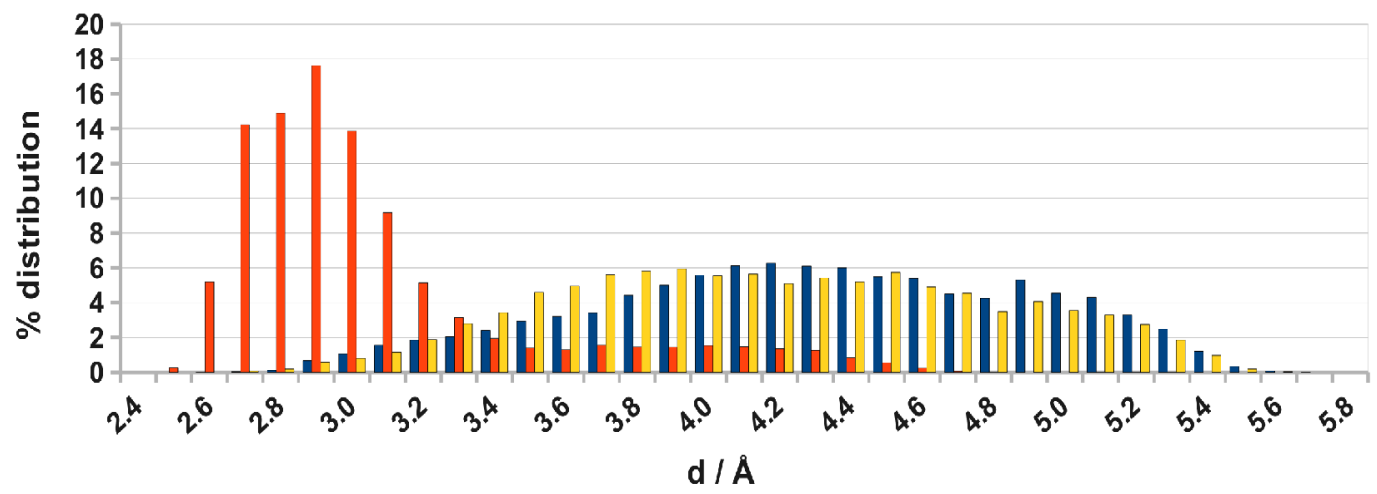

Figure 21. The percentage distribution of the structures according to the measured distance between

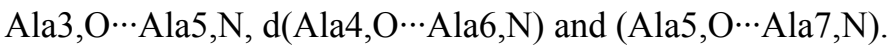

The distribution of the distance between the carbonyl oxygen of $\mathrm{Ala}_{3}, \mathrm{Ala}_{4}$ and $\mathrm{Ala}_{5}$ (residue " $\mathrm{i}$ ") of ALA and the amide hydrogen of its corresponding " $\mathrm{i}+2$ " residue, $\mathrm{Ala}_{5}, \mathrm{Ala}_{6}$ and $\mathrm{Ala}_{7}$, respectively, was plotted to determine whether hydrogen bonds between these residue pairs can enable $\gamma$-turn formation. The same residue pairs were plotted for the ALR peptide (Figure 21). A similar distribution of the inter-atomic distances was shown for ALA and ALR when Ala or $\mathrm{Alr}_{5}$ was at the residue was the first or third residue of the "i" or at the residue " $i+2$ " position. These values were most frequently between $3.8 \AA$ and $4.1 \AA$ 
in ALA, and between $4.1 \AA$ and $4.4 \AA$ in ALR. However, this distance is reduced to approximately $2.95 \AA$ in ALR when $\mathrm{Alr}_{5}$ is the central residue " $\mathrm{i}+1$ " of the turn. This distance shortening increased the propensity of hydrogen bonds to to form between the atom pairs, and enabled $\gamma$-turns to form in this region of the peptide.

The density Ramachandran map (Figure 22) indicates that the most populated region of the Ramachandran space of $\mathrm{Ala}_{5}$ was when $\phi$ was between $-90^{\circ}$ and $-60^{\circ}$ and when $\psi$ was between $-30^{\circ}$ and $0^{\circ}$, which contained $13.6 \%$ of the structures. The highest populated region occupied $\mathrm{Alr}_{5}$ was when $\phi$ was between $-30^{\circ}$ and $0^{\circ}$ and when $\psi$ was between $-60^{\circ}$ and $-30^{\circ}$, which includes $21.7 \%$ of the structures. Moreover, the Ramachandran map of $\mathrm{Alr}_{5}$ shows that the region where $\phi$ is between $-30^{\circ}$ and $30^{\circ}$ was also highly populated.
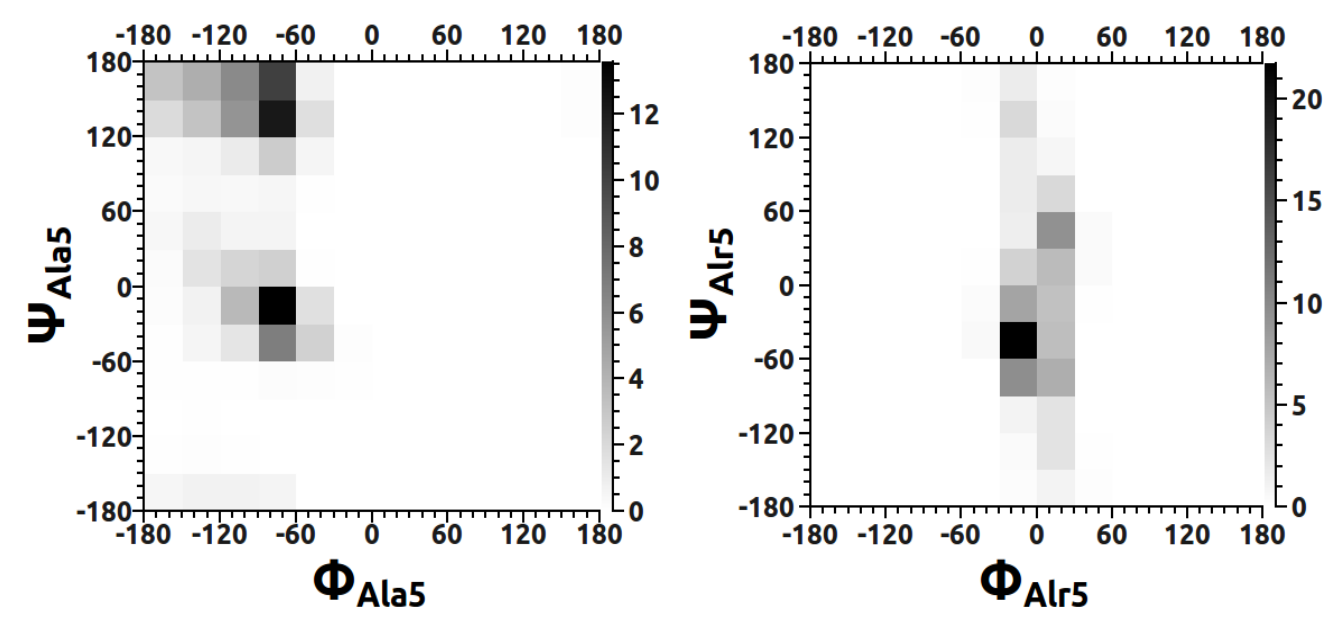

Figure 22. The density (top) and classic (bottom) Ramachandran maps of the central amino acid (Ala5 or Alr5) for ALA (left panel) and ALR (right panel). 


\subsection{DISCUSSION}

\subsection{Consequences of $C_{\alpha}$ Radical Formation on Monopeptide Conformers}

The use of the acetyl and $\mathrm{N}$-methyl amide groups to protect the $\mathrm{N}$ - and $\mathrm{C}$ - termini, respectively, helps conserve the electronic environment of the $\mathrm{C}^{\alpha}$ center of amino acid residues since the $\mathrm{C}^{\alpha}$ is between two amide bonds. The methyl carbons of the $\mathrm{N}$ - and $\mathrm{C}$ terminal acetyl and $N$-methyl amide groups, respectively, correspond to $\mathrm{C}^{\alpha}$ of the adjacent amino acid residues in an extended polypeptide structure. Thus, the steric interactions between the $\mathrm{C}^{\alpha}$ and the adjacent amide bonds can be taken into consideration and contributions to local $\mathrm{C}^{\alpha}$ structure from other residues in a polypeptide are avoided..$^{79-81}$

The relatively flat potential energy surface of $N$-Ac-Gly-NHMe, matches the characteristic flexibility of Gly in proteins. Conformations in both D and L configuration can easily be accessed by Gly and this is demonstrated by the absence of large energy barriers between the minima. The "flat valleys" between these conformations indicate that the structures are stable but conformations of Gly can inter-convert easily. The PES of the $\mathrm{N}$ Ac-Gly-NHMe was substantially different from that of its closed-shell counterpart. The $\beta_{\mathrm{L}}$ conformation was the most stable structure on the PES and was surrounded by a high-energy rim, trapping the $\phi$ and $\psi$ angles in $\beta_{\mathrm{L}}$ conformation. Furthermore, because the other minima are shallow and a relatively small amount of energy could bring the structure back to the more stable $\beta_{\mathrm{L}}$ conformation. It is evident that changes in hybridization of the $\mathrm{C}^{\alpha}$ has a large effect on its PES. The $\mathrm{sp}^{3}$-hybridized $\mathrm{C}^{\alpha}$ of the Gly residue generates three low energy conformations, gauche ${ }^{+}$, gauche $e^{-}$and anti (Figure 9A). This is displayed in the closed shell 
model. With two hydrogen atoms bonded to the $\mathrm{C}^{\alpha}$, however, only the steric hindrance of the amide bonds provides a significant energy barrier. The $\phi=0^{\circ}$ line on the PES illustrates this. On the other hand, the $\mathrm{sp}^{2}$-hybridized $\mathrm{C}^{\alpha}$-centered radical has only two low energy conformations, which indicates the tendency of the $\mathrm{C}^{\alpha}$-centered radical to adopt planar $(\phi$ and $\psi$ angles of $0^{\circ}$ or $180^{\circ}$ ) conformations. The adoption of planar conformations following radical formation by the Gly residue may facilitate the formation of $\beta$-sheets, with $\mathrm{H}$ - bonds stabilizing the interactions between $\beta$-strands.

\subsection{H-Abstraction from Amino Acid Monopeptides}

The structures and energies of the Ala and Gly pre-reaction van der Waals complexes, transition states, and post-reaction van der Waals complexes will be discussed in the subsequent sections.

\subsubsection{The Pre-Reaction van der Waals Complexes}

The difference between the relative energies of the Gly and Ala pre-reaction complexes shows that the Ala side chain could inhibit the formation of the $\gamma_{D}$ and $\alpha_{D}$ pre-reaction complexes. The relative energies of the $\beta_{L}, \gamma_{D}, \alpha_{L}$ and $\alpha_{D}$ pre-reaction complexes of Gly are within $4 \mathrm{~kJ} \mathrm{~mol}^{-1}$ of each other, whereas the $\gamma_{\mathrm{L}}$ is a slight outlier, which suggests that the prereaction complex can form easily from multiple conformations. The distribution of the prereaction Ala energy values is similar, however the $\alpha_{D}$ and $\gamma_{D}$ complexes are higher in energy. It is worth noting that the $\alpha_{\mathrm{D}}$ pre-reaction complex is is only $1.4 \mathrm{~kJ} \mathrm{~mol}^{-1}$ lower than the energy at the entrance level. The side chain of the Ala residue destabilizes this complex by hindering the ability of the oxygen atom of the ${ }^{\circ} \mathrm{OH}$ radical to interact with the pro-D 
hydrogen of the Ala residue. As a result, the formation energy of the complex in this conformation is $20-25 \mathrm{~kJ} \mathrm{~mol}^{-1}$ less than the other conformations. The complex formation energies of all five conformations of Gly and the four (excluding $\alpha_{D}$ ) of Ala indicate that the formation energies of the pre-reaction complexes are sufficient enough to enable the hydrogen abstraction reaction to occur, particularly when the activation energy is close to zero. $^{82,83}$ When these nine conformations of the residues are considered, the formation energies of the pre-reaction complexes show that the Ala side chain does not significantly inhibit complex formation. Side chains larger than Ala could further hinder complex formation, and a future study could provide a rationale for this effect.

With the exception of the $\gamma_{\mathrm{D}}$ conformation of Gly, the $\phi$ and $\psi$ angles of the Gly and Ala van der Waals complexes are within a few degrees of the $\phi$ and $\psi$ angles of the respective Gly and Ala residues. Therefore these complexes can form without perturbing the structure of the respective Gly and Ala minima, and the differences in relative energy only depend on the interaction between the ${ }^{\circ} \mathrm{OH}$ radical and the respective residues. This can also be expected if explicit water molecules were studied as well, since the ${ }^{\circ} \mathrm{OH}$ would occupy a similar place that a structural $\mathrm{H}_{2} \mathrm{O}$ molecule would occupy. The lack of conformational change of the residues during complex formation with ${ }^{\circ} \mathrm{OH}$ enables the $\mathrm{H}$-abstraction reaction to occur with greater ease.

\subsubsection{The Transition State Structures}

Both Gly and Ala combine with ${ }^{\circ} \mathrm{OH}$ to form six and seven-membered rings in the respective transition state structures (Figure 11 and Figure 12). The $\phi$ and $\psi$ angles of the 
Gly transition state structures remain similar to those of the Gly PES, whereas the $\psi$ angle of $\gamma_{\mathrm{D}}$ becomes more like the $\psi$ angle of Gly: The change in the $\beta_{\mathrm{L}}$ conformation of Ala transition state suggests that the capto-dative stabilization of Ala in this conformation is less than that of Gly, and is likely to be the reason for the decreased relative energy of the Ala $\beta_{\mathrm{L}}$ transition state. It can be concluded that the transition states for each conformation of the Gly and Ala residues except for the $\gamma_{\mathrm{D}}$ of Gly and $\beta_{\mathrm{L}}$ of Ala deviate from the geometries of the PES minima by only a few degrees.

Both the Gly and Ala transition states in the $\beta_{\mathrm{L}}$ conformation are below the entrance level, and the next lowest lying transition states of Gly are the $\gamma_{D}$ and $\alpha_{D}$ conformations, followed by the $\gamma_{\mathrm{L}}$ and $\alpha_{\mathrm{L}}$ conformations. The $\phi$ and $\psi$ angles indicate that the $\beta_{\mathrm{L}}$ conformation is capto-dative stabilized, and is the reason for the low-lying $\beta_{\mathrm{L}}$ conformation, however the differences between the energy of the other conformations are less significant. After the $\beta_{\mathrm{L}}$ conformation, the next lowest-lying transition states of Ala are the $\gamma_{\mathrm{L}}$ and $\gamma_{\mathrm{D}}$, followed by the $\alpha_{L}$ and $\alpha_{D}$ transition states which are much higher in energy. The Ala side chain has a larger influence on the energy of these conformations, and a distinct conformational effect can be observed in Ala.

\subsubsection{The Post-Reaction van der Waals Complexes with $\mathrm{H}_{2} \mathrm{O}$}

The relative energy values of the Gly and Ala post-reaction van der Waals (Table 6) complexes were similar to those of the respective Gly and Ala ${ }^{\bullet}$ PES minima shown in

Table 4. The geometries of the post-reaction complexes only varied from the fully isolated Gly and Ala residues by a few degrees, except for the $\alpha_{\mathrm{L}}$ complex of Gly and Ala, which are 
not similar to any of the respective $\mathrm{Gly}^{*}$ or $\mathrm{Ala}^{*}$ conformations. Moreover, the corresponding $\alpha_{D}$ conformation of Gly converged to the $\gamma_{D}$, which can be attributed to the absence of the methyl group of the Ala side chain. The post-reaction complexes of the Gly residue were more planar than the respective Ala ${ }^{*}$ complex, which is probably due to the increased capto-dative stabilization of the Gly residue. The $\mathrm{H}_{2} \mathrm{O}$ molecule interacts with the Gly and Ala with a hydrogen bond between a hydrogen atom of water and one of the carbonyl oxygen atoms (Figure 11 and 12). In the $\gamma_{\mathrm{L}}$ and $\alpha_{\mathrm{L}}$ complexes of Gly and the $\gamma_{\mathrm{L}}$ of Ala hydrogen bonds form with both carbonyl oxygen atoms, but these complexes are the highest in energy.

The post-reaction complexes of Gly are $120.7-159.8 \mathrm{~kJ} \mathrm{~mol}^{-1}$ below the energy of the entrance level, and those of Ala are 137.1 - $156.4 \mathrm{~kJ} \mathrm{~mol}^{-1}$ below the Ala entrance level. This complex is the lowest point of the reaction coordinate for both the Gly and Ala residue, and the stability of these complexes show that their formation is a significant driving force for the progress of the $\mathrm{H}$ abstraction reactions. The side chain of Ala does not appear to interact with the $\mathrm{H}_{2} \mathrm{O}$ molecule, and the stability of the complex is largely influenced by the hydrogen bond between the water molecule and the residue, and by the $\phi$ and $\psi$ angles of the residue. This is supported by the observation that these angles remain similar to those of the respective Gly and Ala residues in the absence of the the $\mathrm{H}_{2} \mathrm{O}$ molecule. The $\phi$ and $\psi$ angles of Gly and Ala are expected be similar if this system were to include structural water.

\subsubsection{H-Abstraction by Gly $^{\circ}$ and Ala ${ }^{\bullet}$ Radicals from $\mathrm{H}_{2} \mathrm{O}_{2}$}

To quantify the stability of the $\mathrm{C}_{\alpha}$-centered radical of Gly and Ala ${ }^{*}$ we also compared the 
reaction coordinates for the hydrogen abstraction from $\mathrm{H}_{2} \mathrm{O}_{2}$ by $\mathrm{Gly}^{*}$ and Ala, in order to form the Gly and Ala residues. $\mathrm{H}_{2} \mathrm{O}_{2}$ can donate a hydrogen atom and can be found in areas of the body where ${ }^{\circ} \mathrm{OH}$ can be found as well. It should be stressed that $\mathrm{H}_{2} \mathrm{O}_{2}$ is not the only molecule that can play this role, but it has been selected as an example. The $\beta_{\mathrm{L}}$ conformation of these residues was used as the starting conformation because they are the lowest in energy, as shown in the potential energy surfaces (Figure 10). Both the Gly and Ala residues are likely to unfold to the $\beta$ conformer following hydrogen abstraction from any of the other conformers. The formation energy of the van der Waals complex is the same for both residues, however, the lower lying transition state and subsequent van der Waals complex and separated products of the Ala residue shows that the Ala would be easier to convert back to Ala, whereas the Gly ${ }^{*}$ would have a higher propensity to remain a $\mathrm{C}_{\alpha}$ radical, as shown in Figure 21. A representative scheme of the reaction coordinate for the reformation of Gly and Ala can be found in Figure 22.

Since the energy of the Gly- ${ }^{\cdot} \mathrm{OH} / \mathrm{Gly}^{*}-\mathrm{H}_{2} \mathrm{O}_{2}$ and Ala- $\mathrm{OH} / \mathrm{Ala} \cdot-\mathrm{H}_{2} \mathrm{O}_{2}$ systems remain below the energy of the entrance level, the re-formation to Gly and Ala by $\mathrm{H}_{2} \mathrm{O}_{2}$ has enough energy to proceed. Using Gly as an example, it has been shown that the post-reaction complexes contain Gly in the $\beta_{\mathrm{L}}, \gamma_{\mathrm{L}}$ and $\delta_{\mathrm{D}}$ conformations, whereas the Gly PES indicated that other Gly minima are stable. However, the relative energy values of Gly ${ }^{\bullet}$ PES minima indicate that the $\beta_{\mathrm{L}}$ conformation is approximately $30 \mathrm{~kJ} \mathrm{~mol}^{-1}$ more stable. This can also be said for Ala and presumably for any other residue. This suggests that any rearrangement of the residue will result in the residue converting to the $\beta_{\mathrm{L}}$ conformation. These results can 


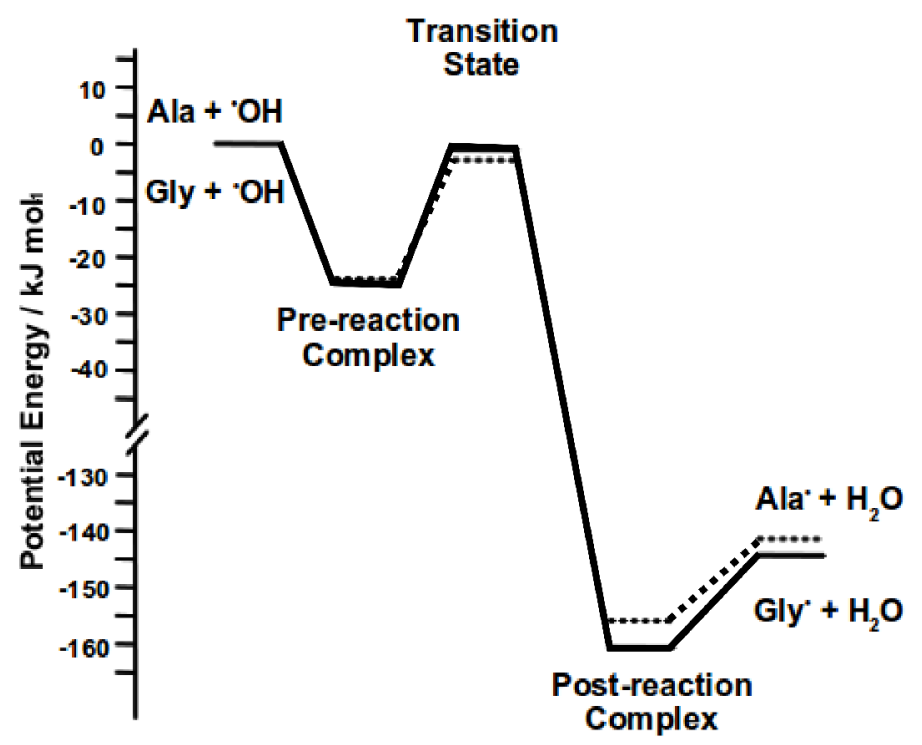

Figure 21. The reaction coordinate diagram showing the $\mathrm{E}_{\mathrm{pot}}$ of the hydrogen abstraction from Gly and Ala in the $\beta_{\mathrm{L}}$ conformation by ${ }^{\circ} \mathrm{OH}$. The energy of the reactants is used as a reference.

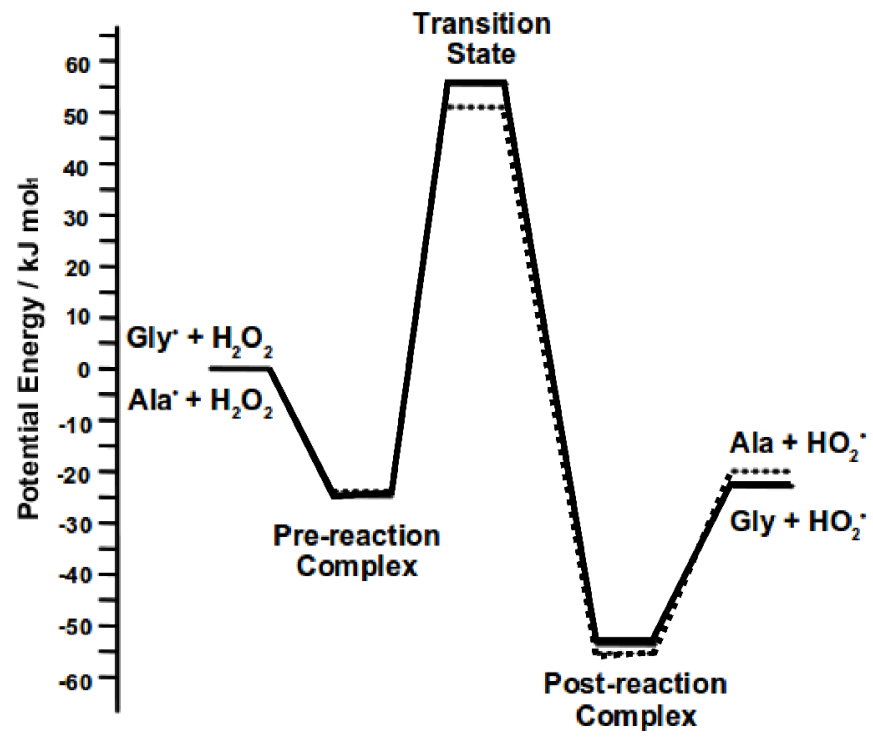

Figure 22. The reaction coordinate diagram showing the $\mathrm{E}_{\mathrm{pot}}$ of the hydrogen abstraction from $\mathrm{H}_{2} \mathrm{O}_{2}$ by Gly ${ }^{*}$ and Ala in the $\beta_{\mathrm{L}}$ conformation. The energy of the reactants is used as a reference. 
help elucidate the mechanism by which ${ }^{\circ} \mathrm{OH}$ initiates protein unfolding, and potential aggregation. It would be interesting to see whether the conversion to the $\beta_{\mathrm{L}}$ conformer that was shown here can be reproduced using other techniques, particularly molecular dynamics, which enables the time-dependent nature of this unfolding to be observed in larger systems.

\subsection{Deviations from the $\mathrm{G5}$ and $\mathrm{A} 5$ structures}

\subsubsection{Structural Perturbations due to $\mathrm{C}_{\alpha} \mathrm{H}$-Abstraction from G5 and A5}

The shift towards the $\beta$ conformation $\left(\phi, \psi=180^{\circ}\right)$ is in agreement with that shown in a glycyl diamide model, in which the $\beta$ conformation was shown to be the most stable. ${ }^{80}$ Allyl-type radicals have a higher stability compared to non-delocalized radicals and also favor the planar conformation. This structure has been shown to have a rotational energy barrier of approximately $15 \mathrm{kcal} \mathrm{mol}^{-1} \cdot{ }^{66,84,85}$ The stability of this conformation can be attributed to the overlap of the semi-occupied $\pi$-orbital of the radical with the p-orbitals of the amide nitrogen and carbonyl carbon. This structure stabilizes the $\mathrm{C}_{\alpha}$ radical of $\mathrm{G} 5\left(\mathrm{C}_{\alpha}{ }^{\circ}\right)$ and $\mathrm{A} 5\left(\mathrm{C}_{\alpha}{ }^{\circ}\right)$ due to the conjugation between the nitrogen atom of the amide and carbon atom of the carbonyl group, which has also been shown previously in cyclic and amino alkyl compounds. ${ }^{86,87}$ Further evidence of the delocalization is the decreased length of the N-C ${ }_{\alpha}$ and $\mathrm{C}_{\alpha}-\mathrm{C}$ bonds, which indicates an increase in double-bond character. The increase in the $\mathrm{C}_{\alpha}-\mathrm{C}$ bond length was observed in the extended structure, but not in the helix, indicative of the tendency of the helix to inhibit the delocalization of the unpaired electron. The increased length of the amide bonds between residues "i" and " $i$ - 1 " and the amide bond between residues " $\mathrm{i}$ " and " $\mathrm{i}+1$ " of both $\mathrm{G} 5$ and A5 indicates that these bonds become more like 
single bonds, which are weaker and are more susceptible to enzymatic degradation and peptide fragmentation.

The stabilization of the radical by the amide nitrogen of $\mathrm{G} 5\left(\mathrm{~N}^{*}\right)$ and $\mathrm{A} 5\left(\mathrm{~N}^{*}\right)$ is twofold, due to the electron-donating properties of the amide nitrogen, and the ability of the amide bond to delocalize the unpaired electron. ${ }^{88}$ The stronger $\mathrm{C}_{\alpha}{ }^{\cdot}$ coupling to the amide nitrogen than to the carbonyl carbon is shown in the larger change in bond length in both $\mathrm{G} 5\left(\mathrm{C}_{\alpha}{ }^{\circ}\right)$ and $\mathrm{A} 5\left(\mathrm{C}_{\alpha}{ }^{\circ}\right)$. The increased planarity of $\mathrm{Ala}^{3}$ is shown by the lack of pleats in the extended conformation (Figure 19) and $\phi$ and $\psi$ angles of nearly $180^{\circ}$. An increase in the planarity of the atoms in $\mathrm{Gly}^{3}$ and $\mathrm{Ala}^{3}$ was also shown in the helical conformation (Figures 17 and 20), with both the $\phi$ and $\psi$ angles approaching $0^{\circ}$ (Tables 9 and 11). It can be observed that this effect does not carry over to residue 2 or residue 4 of the G5 and A5 peptides in either the extended or helical conformations.

\subsubsection{Structural Perturbations due to Amide Nitrogen H-Abstraction from G5 and A5}

Numerous theoretical studies have been done on hydrogen atom abstraction from the free amino group, with some suggesting the that the amino hydrogen is the preferred target by ${ }^{\circ} \mathrm{OH} \cdot{ }^{44,89,90}$ However, when the amide nitrogen is derivatized it was shown that reactions at the side chain are always preferred. ${ }^{91}$ Although free amino acids and their derivatives can provide a good description of local electronic effects, hydrogen abstraction from the amide bond of model peptides helps determine the effect of long-range interactions and hydrogen bonding. The removal of a hydrogen atom from G5 and A5 showed an increase of the amide bond length with the adjacent carbonyl carbon, along with the an increase in the length of 
the $\mathrm{C}_{\alpha}-\mathrm{C}$ bond. The $\mathrm{N}-\mathrm{C}_{\alpha}$ bond length decreased, which is consistent with the formation of an imine..$^{92}$

The most significant effect of the H-atom abstraction from the amide nitrogen is due to the rearrangement of the hydrogen bonds within the G5 and A5 peptides. Instead of the intra-residue hydrogen bond between the amide nitrogen and carbonyl oxygen of $\mathrm{Gly}^{3}$ and $\mathrm{Ala}^{3}$ in the extended conformation, a hydrogen bond formed between the carbonyl oxygen of residue " $i-1$ " and the amide hydrogen of residue " $i+1$ ". It is presumed that this caused the observed deviation in the $\phi$ and $\psi$ dihedral angles in this structure compared to those of the G5 and A5 extended $\phi$ and $\psi$ angles. In the helical conformation, the removal of the Gly ${ }^{3}$ and $\mathrm{Ala}^{3}$ amide hydrogen atoms eliminated the hydrogen bonds that were formed with residue 3 and the carbonyl carbon of residue 1 . The observed increase in the amide bond length suggests that $\mathrm{N}^{*}$-containing peptides can be more labile than in a peptide without a radical.

\subsubsection{Structural Perturbations due to $\mathrm{C}_{\beta} \mathrm{H}$-Abstraction from A5}

The change in length of the amide bond between adjacent residues is indicative of the coupling between the methyl group and the resonance structures of the amide bond. ${ }^{93}$ However, compared to the effect of radical formation on the $\mathrm{C}_{\alpha}$ and amide nitrogen on the peptide structures, this coupling is relatively weak. Apart from the length of the $C_{\alpha^{-}} C_{\beta}$ bond, $\mathrm{C}_{\beta}$-radical formation had a negligible effect on the bond lengths, dihedral angles, or hydrogen bonds of either the extended or helical A5 peptide. The methyl group of Ala is the $\beta-\mathrm{CH}_{2}$ of the other amino acids apart from glycine, and it is expected that radical formation 
at this or any other position of the side chain would have negligible inductive effects on the conformation of the peptide backbone. Moreover, the effect on the length of the amide bond is negligible, suggesting that side chain oxidation does not cause the peptide bond to weaken.

The RMSD values indicate that the $\mathrm{H}$ abstraction from the $\mathrm{C}_{\beta}$ did not significantly change the structure of A5. $\mathrm{H}$ abstraction from the $\mathrm{C}_{\alpha}$ increased the planarity of the peptide but the secondary structure of the peptide remained intact, whereas $\mathrm{H}$ abstraction from the amide nitrogen altered the secondary structure of the peptide.

\subsection{Thermodynamic Analysis}

\subsubsection{H-Abstraction Energy and Stability of Peptide Radicals}

It is expected that with the increase in the number of delocalized electrons in the conjugated system the stability of the radical will increase. ${ }^{94}$ This phenomenon will contribute to the lower dissociation energy of the $\mathrm{C}_{\alpha}-\mathrm{H}$ bond compared to that of the $\mathrm{C}_{\beta}-\mathrm{H}$ and N-H bonds. The lower relative bond dissociation energy of the extended peptide compared to that of the helical conformation is similar to results shown by others, however the secondary structures were mimicked with the use of smaller peptide fragments. ${ }^{43,64}$ The use of model pentapeptides enables the inclusion of intra-molecular hydrogen bond effects of the secondary structural elements. The conformational dependence shown in the smaller fragments was shown to be less in the pentapeptides computed herein, suggesting that the diamide models may exclude the stabilization effect of intra-molecular hydrogen bonding. The similarity of the BDE results computed at the $6-31 \mathrm{G}(\mathrm{d})$ and $6-311+\mathrm{G}(\mathrm{d}, \mathrm{p})$ basis sets 
indicate that the inclusion of diffuse functions and polarizable functions on hydrogen did not significantly improve the BDE values. It is possible that capto-dative stabilization and the larger number of delocalized electrons of the $\mathrm{G} 5\left(\mathrm{C}_{\alpha}\right)$ and the $\mathrm{A} 5\left(\mathrm{C}_{\alpha}\right)$ are reasons for the relative stability. These results also agree with experimental results that state that ${ }^{\circ} \mathrm{OH}$ attack at the $\mathrm{C}_{\alpha}$ position of Ala peptides are favored over $\mathrm{C}_{\beta} \cdot{ }^{44,91}$

\subsubsection{Helical Unfolding}

The use of computational chemistry enables the stability of radicals at specific sites and the relative stability of otherwise transiently stabilized structures to be evaluated. This information can help measure the thermodynamic functions and determine the stability of folding intermediates, which can provide insight into unfolding mechanisms. Here, the $\Delta \mathrm{G}^{\mathrm{o}}$ values indicate that the unfolding of the G5 and A5 peptides from a $3_{10}$-helix to an extended conformation is favorable, but much more so when there is a $\mathrm{C}_{\alpha}$ present on residue 3. The similarity between the $\Delta \mathrm{G}^{\text {o }}$ for the unfolding of $\mathrm{G}\left(\mathrm{N}^{*}\right), \mathrm{A} 5\left(\mathrm{C}_{\beta}{ }^{\circ}\right)$ and $\mathrm{A} 5\left(\mathrm{~N}^{*}\right)$ to that of the respective G5 and A5 peptides suggests that the propensity of these structures to unfold is not significantly greater than that of the G5 or A5 peptides. It has been shown that radical formation on peptides causes peptides and proteins to unfold, and it has been hypothesized as a possible mechanism for the aggregation of amyloid peptides. ${ }^{95,96}$ These results indicate that the unfolding of $\mathrm{G} 5$ and $\mathrm{A} 5$ are more favorable when a $\mathrm{C}_{\alpha}$ radical is present. If a radical was to form at the $C_{\beta}$ or amide nitrogen, then a hydrogen transfer reaction is likely to preclude unfolding. According to several experimental studies, intramolecular hydrogen transfer reactions almost exclusively result in the formation of $C_{\alpha}$ radicals. ${ }^{97-99}$ The 
unfolding of all investigated peptides results in an increase in entropy, which can also drive peptides and proteins to unfold. The $\mathrm{C}_{\beta}$ and amide nitrogen peptide radicals do not show a significantly larger propensity than A5 or G5 to unfold. Therefore, radical-initiated unfolding is likely to be a result of the formation of the $\mathrm{C}_{\alpha}$ radical.

\subsubsection{Reactions of Pentapeptides with Reactive Oxygen Species}

The results in a model peptide indicate that hydrogen abstraction by the ${ }^{\circ} \mathrm{OH}$ radical is favorable from each of the three positions, which is consistent with what was shown in model amides. ${ }^{100}$ This study also showed that abstraction from the amide nitrogen was the least favored, which can be attributed to the relative stability of the amide bond. Hydrogen abstraction from the amide nitrogen also had the largest change in entropy when G5 and A5 were in the helical conformation. The smaller gain in entropy can be observed in the extended conformation because the intra-residue hydrogen bond in residue 3 is replaced with a hydrogen bond between the carbonyl oxygen of residue 3 and the amide nitrogen of residue 2. The reaction at the $\mathrm{C}_{\alpha}$ is the most endergonic and is enthalpy driven, due to the stabilization discussed previously. In spite of the large endergonicity the associated gain in entropy of reactions at the $\mathrm{C}_{\alpha}$ is less than at the other sites, though the differences are not significantly different to that measured at the $\mathrm{C}_{\beta}$ in the case of $\mathrm{A} 5$.

The reactivity of ${ }^{\circ} \mathrm{OH}$ can be attributed to the high dissociation energy of the $\mathrm{O}-\mathrm{H}$ bond in $\mathrm{H}_{2} \mathrm{O}$, which is $499.2 \mathrm{~kJ} \mathrm{~mol}^{-1}{ }^{101}$ Accordingly, reactions with the ${ }^{\bullet} \mathrm{OH}$ radical are exergonic at the $\mathrm{C}_{\alpha}, \mathrm{C}_{\beta}$ and amide nitrogen sites in all conditions calculated herein. Despite being the most endergonic, the largest gain in entropy was measured in the reactions with the $\mathrm{O}_{2}{ }^{-}$ 
radical, which, in addition to the $\Delta \mathrm{H}$ measured directly, indicates that the change in enthalpy was the least favorable in this ROS.

These results indicate that a hydrogen atom from the $\mathrm{C}_{\alpha}, \mathrm{C}_{\beta}$ and amide nitrogen can be abstracted by ${ }^{\bullet} \mathrm{OH}$ but not by $\mathrm{HO}_{2}{ }^{\bullet}$ or $\mathrm{O}_{2}{ }^{-}$. It is well known that the ${ }^{\circ} \mathrm{OH}$ is the most reactive, but it has also been shown that ${ }^{\circ} \mathrm{OH}$ is more destructive when $\mathrm{HO}_{2}{ }^{\bullet}$ or $\mathrm{O}_{2}{ }^{-}$are present. A hypothesis for this phenomenon is discussed in the next section.

\subsubsection{Thermodynamic Cycles of H-Abstraction}

As discussed previously, the oxidation of proteins has been shown to cause proteins to unfold. Moreover, it has been hypothesized that radical-initiated protein unfolding is the first step in the mechanism that causes the formation of the amyloid plaques, which are hallmarks of Alzheimer's, Creutzfeld-Jakob, and Parkinson's diseases. ${ }^{102}$ The results obtained herein allow for quantification of the thermodynamic parameters of this process and enables the comparison of the propensity of ${ }^{\circ} \mathrm{OH}, \mathrm{HO}_{2}{ }^{\bullet}$ and $\mathrm{O}_{2}{ }^{\bullet}$ radicals to initiate this process. The $\Delta \mathrm{H}^{\circ}, \Delta \mathrm{G}^{\circ}$ and $\Delta \mathrm{S}^{\circ}$ for the oxidation of the helical G5 and A5 by ${ }^{\circ} \mathrm{OH}$ are all favorable, whereas oxidation by $\mathrm{HO}_{2}{ }^{-}$and $\mathrm{O}_{2}^{-}$are not favorable. After the endothermic, exergonic and entropically favorable unfolding of $\mathrm{G}_{\mathrm{HEL}^{\circ}}$ and $\mathrm{A} 5_{\mathrm{HEL}}{ }^{\circ}$, the $\Delta \mathrm{H}^{\circ}$ and $\Delta \mathrm{G}^{\circ}$ for the formation of the reduced and extended $\mathrm{G} 5$ and $\mathrm{A} 5$ by $\mathrm{H}_{2} \mathrm{O}_{2}$ and $\mathrm{HO}_{2}^{-}$are all negative. Amyloid plaques are not radicals, so in this scheme, the extended G5 and A5 structures best represent the amyloid plaques that have been associated with Alzheimer's disease, and can therefore a suggest a role for $\mathrm{H}_{2} \mathrm{O}_{2}$ and $\mathrm{HO}_{2}^{-}$in the formation of amyloid plaques. This scheme illustrates how each step in the unfolding of G5 and A5 is favorable when ${ }^{\circ} \mathrm{OH}, \mathrm{H}_{2} \mathrm{O}_{2}$ 
and $\mathrm{HO}_{2}^{-}$are present, as shown by Davies et al., in which backbone cleavage and degradation by ${ }^{\circ} \mathrm{OH}$ is exacerbated when $\mathrm{H}_{2} \mathrm{O}_{2}$ and $\mathrm{HO}_{2}{ }^{-}$are also present. ${ }^{10,20,103}$ A schematic comparison between the radical-initiated unfolding of G5 and A5 peptides is shown in Figures 23 and 24. The radical-initiated unfolding of a helix is more favorable than a mechanism without a radical, which would likely involve less stable intermediates.

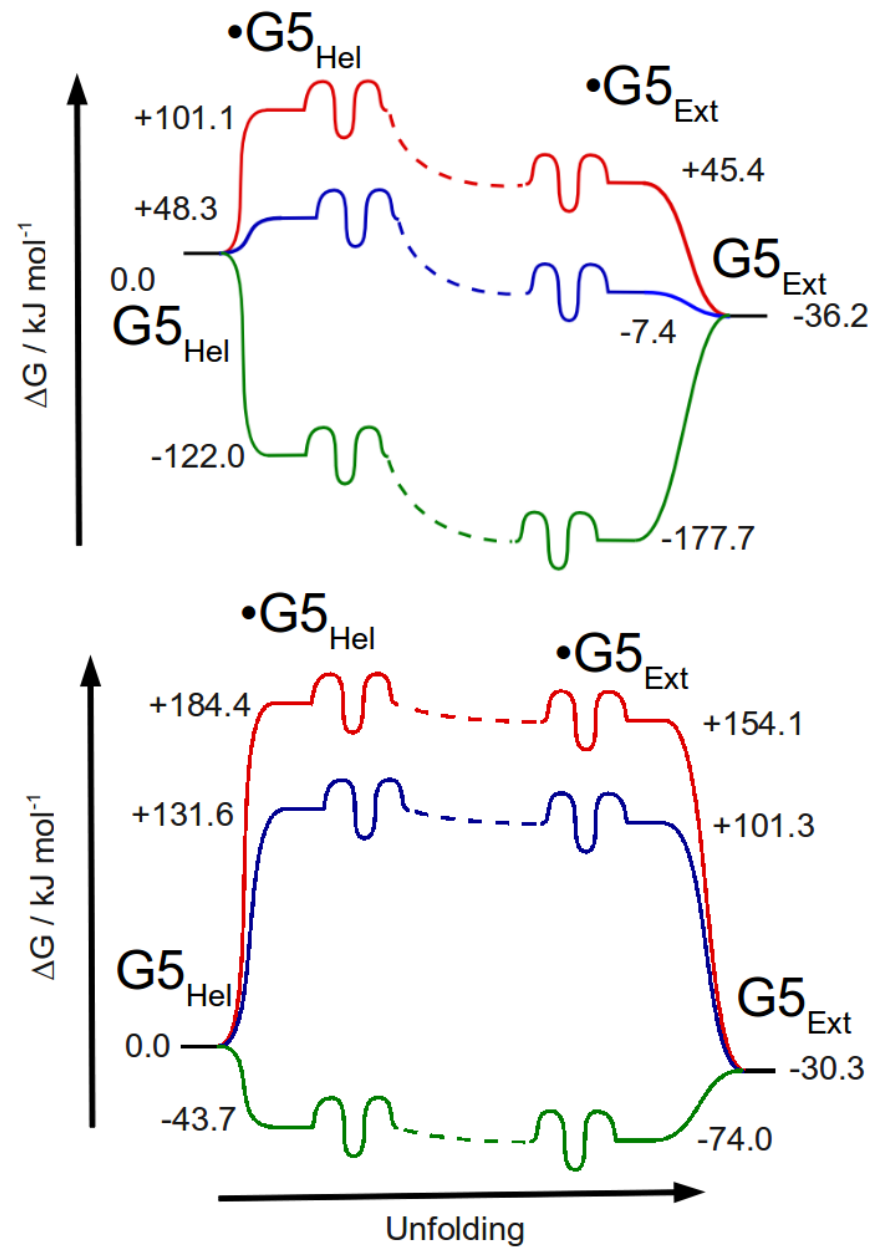

Figure 23. Schematic representations of the $\Delta \mathrm{G}^{\mathbf{0}}$ associated with the radical-initiated conversion of $\mathrm{A} 5_{\mathrm{HEL}}$ to $\mathrm{A} 5_{\mathrm{EXT}}$ by ${ }^{\circ} \mathrm{OH}$,(green), $\mathrm{HO}_{2}{ }^{\circ}$ (blue) and $\mathrm{O}_{2}{ }^{-}$(red). The top panel shows the $\Delta \mathrm{G}^{\circ}$ for the reaction at the $\mathrm{C}_{\alpha}$, whereas the the middle and bottom panels show $\Delta \mathrm{G}^{\circ}$ for $\mathrm{H}$ abstraction from $\mathrm{C}_{\beta}$ and the amide $\mathrm{N}$, respectively.

In Figure 25, competing mechanisms for the conversion of the helical G5 and A5 to and extended $\mathrm{G5}^{\circ}$ and $\mathrm{A} 5^{\circ}$ are shown. The $\mathrm{G} 5^{\circ}$ and $\mathrm{A} 5^{\circ}$ are the forms in which the oxidized 
peptide can propagate, causing new $\mathrm{C}_{\alpha}$ radicalized peptides to form. The $\Delta \mathrm{G}^{\mathrm{o}}$ values of the unfolding of the peptide radicals show that the $\mathrm{G} 5^{\circ}$ EXT and $\mathrm{A} 5_{\text {EXT }}$ conformations of the peptide radicals are more stable, therefore, with its longer half-life, the extended conformations of the peptide radicals are likely to be more toxic.

Amyloidogenic peptides are generally helix forming. In order to form the extended peptide radicals, the helices must either unfold prior to or after oxidation. As shown in Figure 25, the unfolding of the peptides is exergonic for both pathways when oxidized by $\cdot \mathrm{OH}$; however, unfolding prior to oxidation is entropy-driven, whereas oxidation prior to
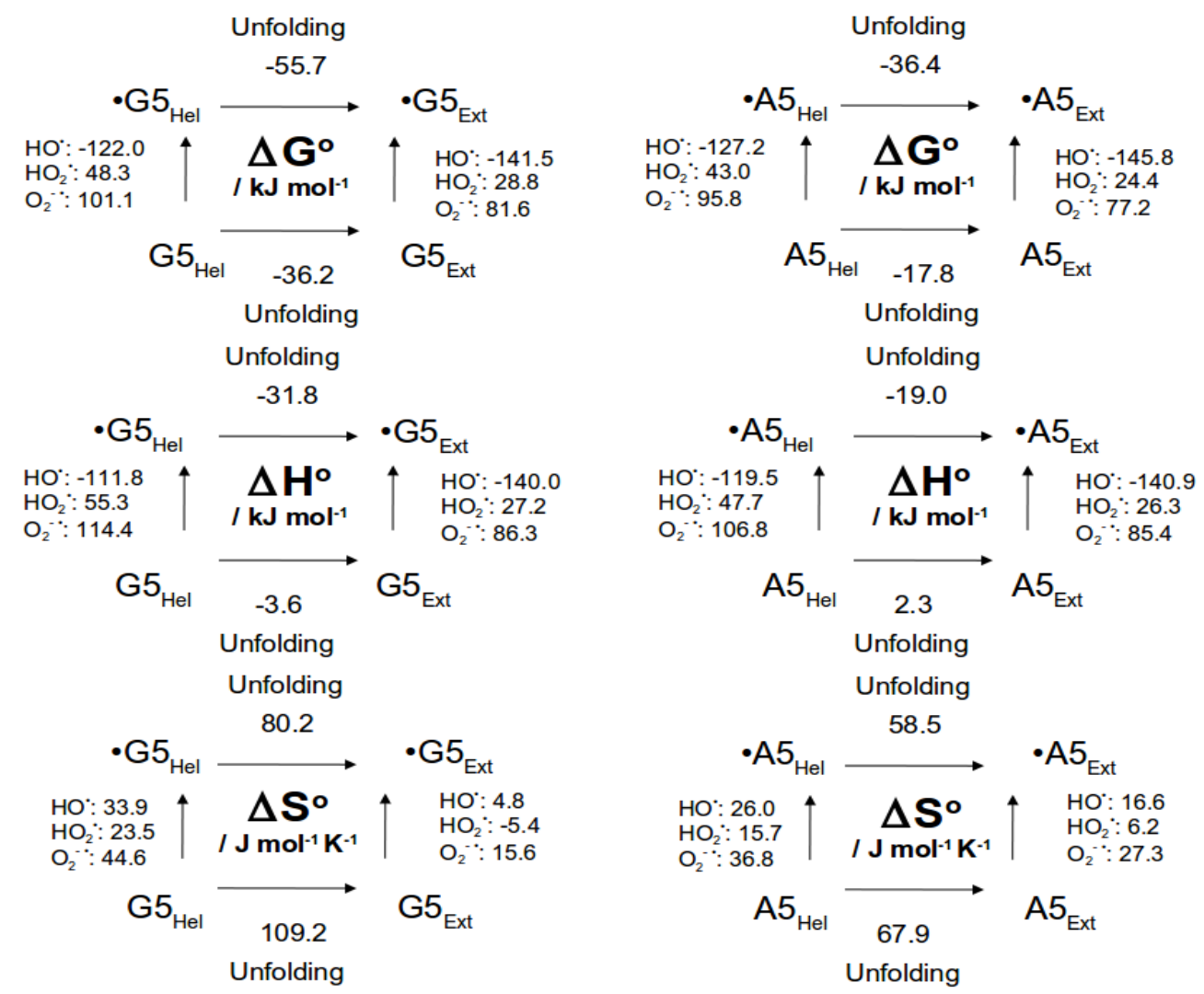

Figure 25. $\Delta \mathrm{H}^{\circ}, \Delta \mathrm{G}^{\circ}$ and $\Delta \mathrm{S}^{\circ}$ for the competing mechanisms of $\mathrm{G} 5_{\mathrm{HEL}}$ (left panel) and $\mathrm{A} 5_{\mathrm{HEL}}$ (right panel) converting to ${ }^{\circ} \mathrm{G} 5_{\mathrm{EXT}}$ and ${ }^{\circ} \mathrm{A} 5_{\mathrm{EXT}}$ initiated by $\mathrm{H}$ abstraction from the $\mathrm{C}_{\alpha}$ of $\mathrm{Gly}^{3}$ and $\mathrm{Ala}{ }^{3}$, respectively, by ' $\mathrm{OH}, \mathrm{HO}_{2}{ }^{\cdot}$ or $\mathrm{O}_{2}{ }^{\cdot}$. In mechanism one (upwards from $\mathrm{G} 5_{\mathrm{HEL}}$ or $\mathrm{A} 5_{\mathrm{HEL}}$ ) the $\mathrm{H}$ abstraction precedes the unfolding. In mechanism two (to the right from $\mathrm{G}_{\mathrm{HEL}}$ or $\mathrm{A} 5_{\mathrm{HEL}}$ ) the unfolding precedes the $\mathrm{H}$-abstraction. 

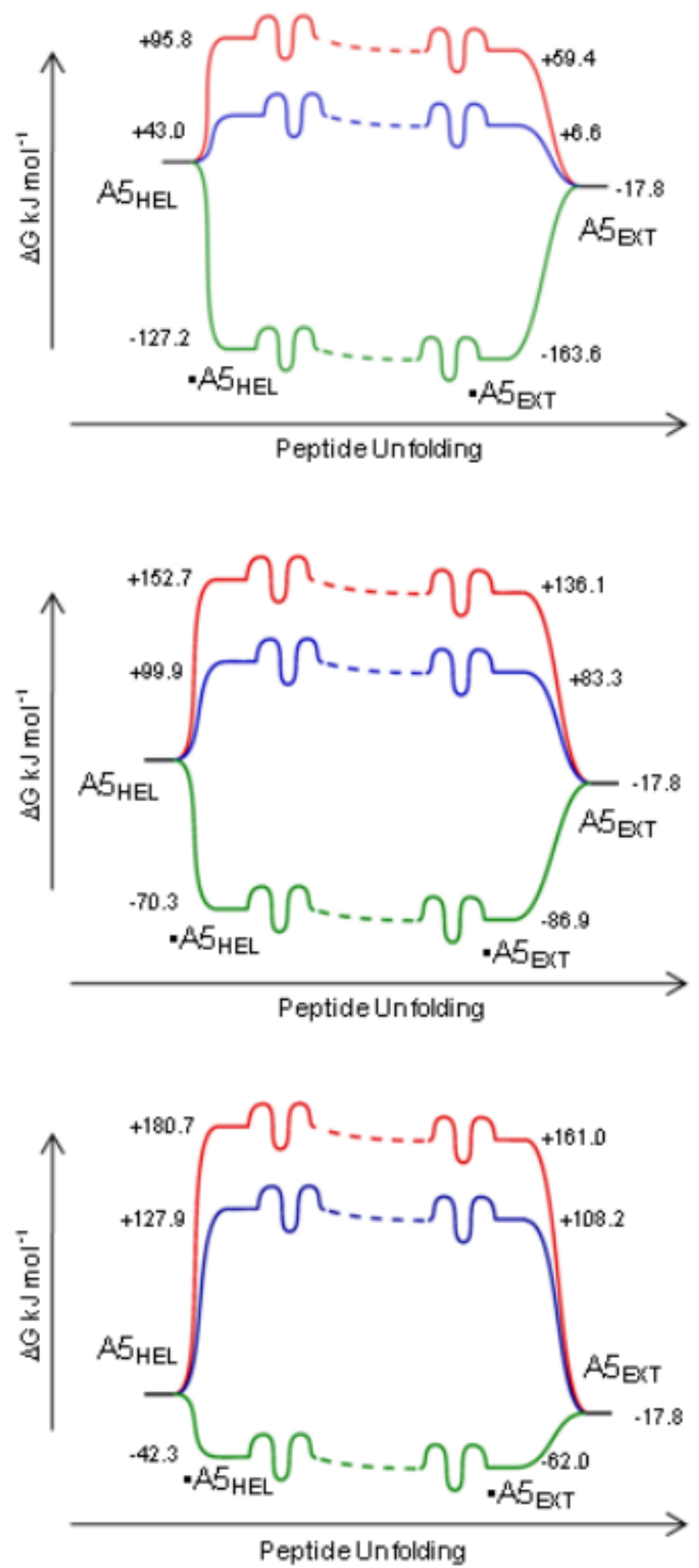

Figure 24. Schematic representations of the $\Delta \mathrm{G}^{\circ}$ associated with the radical-initiated conversion of $\mathrm{G} 5_{\mathrm{HEL}}$ to $\mathrm{G} 5_{\mathrm{EXT}}$ by ${ }^{\circ} \mathrm{OH}$,(green), $\mathrm{HO}_{2}{ }^{\circ}$ (blue) and $\mathrm{O}_{2}^{-{ }^{-}}$(red). The top panel shows the $\Delta \mathrm{G}^{\circ}$ for the reaction at the $\mathrm{C}_{\alpha}$, whereas the bottom panels show $\Delta \mathrm{G}^{\circ}$ for $\mathrm{H}$ abstraction from the amide nitrogen. 
unfolding is enthalpy-driven. In a previous study in which the entropy per residue of homooligomeric peptides was measured, it was shown that there is a greater entropy per each residue added in the extended conformation than in the helical conformation. ${ }^{104}$ The entropy contribution to the helical to extended equilibrium would favor the extended conformation in native peptides, however it remains to be seen how peptide length will affect this equilibrium when a $\mathrm{C}_{\alpha}$ radical is present.

\subsection{Comparison of the Unfolding of G5 to that of A5}

\subsubsection{Geometric Analysis}

A greater decrease in $\mathrm{N}-\mathrm{C}_{\alpha}$ and $\mathrm{C}_{\alpha}-\mathrm{C}=\mathrm{O}$ bond length was shown in the $\mathrm{G} 5$ peptide than for the A5 peptide, whereas the latter peptide showed a greater decrease in the length of the $\mathrm{C}_{\alpha}-\mathrm{R}$ bond length when a $\mathrm{C}_{\alpha} \cdot$ radical was formed. The difference between the G5 and A5 peptides is the identity of the $\mathrm{R}$ group, which is a hydrogen atom in G5 and a methyl group in A5. Since the $\mathrm{sp}^{3}$ orbital of the methyl group is larger than the s orbital of hydrogen, it can accommodate the unpaired electron from the $\mathrm{C}_{\alpha}$ to a larger degree than the s orbital of the hydrogen can. This should be the reason for the larger decrease in the length of the $\mathrm{C}_{\alpha}-\mathrm{N}$ and $\mathrm{C}_{\alpha}-\mathrm{C}=\mathrm{O}$ bonds shown in $\mathrm{G} 5$. This effect was observed both in the extended and helical peptides in the $\mathrm{C}_{\alpha}{ }^{\circ}$-containing peptides, but was not detected in the $\mathrm{N}^{*}$-containing peptides.

The increased delocalization observed after the $\mathrm{C}_{\alpha}$ radical formation caused residue 3 of G5 and A5 to be more planar. Since the G5 $5_{\text {EXT }}$ was already within $1^{\circ}$ of planarity, a greater RMSD was observed in the $\mathrm{A} 5\left(\mathrm{C}_{\alpha}{ }^{\circ}\right)_{\mathrm{EXT}}$ than in the $\mathrm{G} 5\left(\mathrm{C}_{\alpha}{ }^{\circ}\right)_{\mathrm{EXT}}$ compared to the respective $\mathrm{A} 5$ and G5 structures. However, a larger RMSD was shown in $\mathrm{G} 5\left(\mathrm{C}_{\alpha}{ }^{\circ}\right)_{\mathrm{HEL}}$ than in the 
$\mathrm{A} 5\left(\mathrm{C}_{\alpha}\right)_{\mathrm{HEL}}$, which can be attributed to the changes in the local (around the $\mathrm{C}_{\alpha}$ ) electronic environment, as observed in the changes in bond lengths surrounding the $C_{\alpha}$. As such, formation of a $\mathrm{C}_{\alpha}$ radical induced larger changes in the structure of $\mathrm{A} 5_{\mathrm{EXT}}$ than that of $\mathrm{G} 5_{\mathrm{EXT}}$, whereas a larger change was observed in the structure of $\mathrm{G} 5_{\mathrm{HEL}}$, than was observed in $\mathrm{A} 5_{\mathrm{HEL}}$.

\subsubsection{Thermodynamic Analysis}

The dissociation energies of the G5 and A5 $\mathrm{H}-\mathrm{C}_{\alpha}$ bonds are within $2 \mathrm{~kJ} \mathrm{~mol}^{-1}$ of each other in the extended conformation, whereas the $\mathrm{H}-\mathrm{C}_{\alpha}$ bond of $\mathrm{A} 5$ is slightly more labile (by $7 \mathrm{~kJ} \mathrm{~mol}^{-1}$ ) than G5 when the peptides are helices. The differences between the $\mathrm{H}-\mathrm{N}$ dissociation energies of the G5 and A5 peptides were less than $5 \mathrm{~kJ} \mathrm{~mol}^{-1}$. Both the $\mathrm{A} 5\left(\mathrm{C}_{\alpha}{ }^{-}\right)$ and $\mathrm{G} 5\left(\mathrm{C}_{\alpha}{ }^{\circ}\right)$ peptides released more free energy during unfolding than their respective A5 and G5 peptides, however, the $\mathrm{G} 5\left(\mathrm{C}_{\alpha}{ }^{\circ}\right)$ peptide releases $18.4 \mathrm{~kJ} \mathrm{~mol}^{-1}$ more free energy during unfolding than the $\mathrm{A} 5\left(\mathrm{C}_{\alpha}{ }^{\circ}\right)$ peptide does. This indicates that a peptide that has a hydrogen abstracted from a Gly residue will have a greater tendency to unfold than when hydrogen is abstracted from an Ala residue. Since this value for the hydrogen abstraction comes from one residue, this $\Delta \mathrm{G}^{\mathbf{0}}$ value could have a greater significance when multiple residues are considered. Therefore, when considering the hydrogen abstraction from the $\mathrm{C}_{\alpha}$ of peptides and proteins by free radicals, it can be assumed that regions that are rich in glycyl residues would be particularly susceptible to conformational changes.

\subsection{Comparing the MD Simulations to the Potential Energy Surfaces}

The quantum chemically-derived Ala and $\mathrm{Ala}^{\circ}$ potential energy surfaces can be compared to the Ramachandran map for the Ala and Alr residues at position 5 of the 
pentapeptides. The data points of the PES are the same as shown in Section 3.1.1. However, in Figure 26, the IUPAC cut, which goes from $-180^{\circ}$ to $180^{\circ}$ for $\phi$ and $\psi$, is used to enable comparisons to the Ramachandran maps to be made.
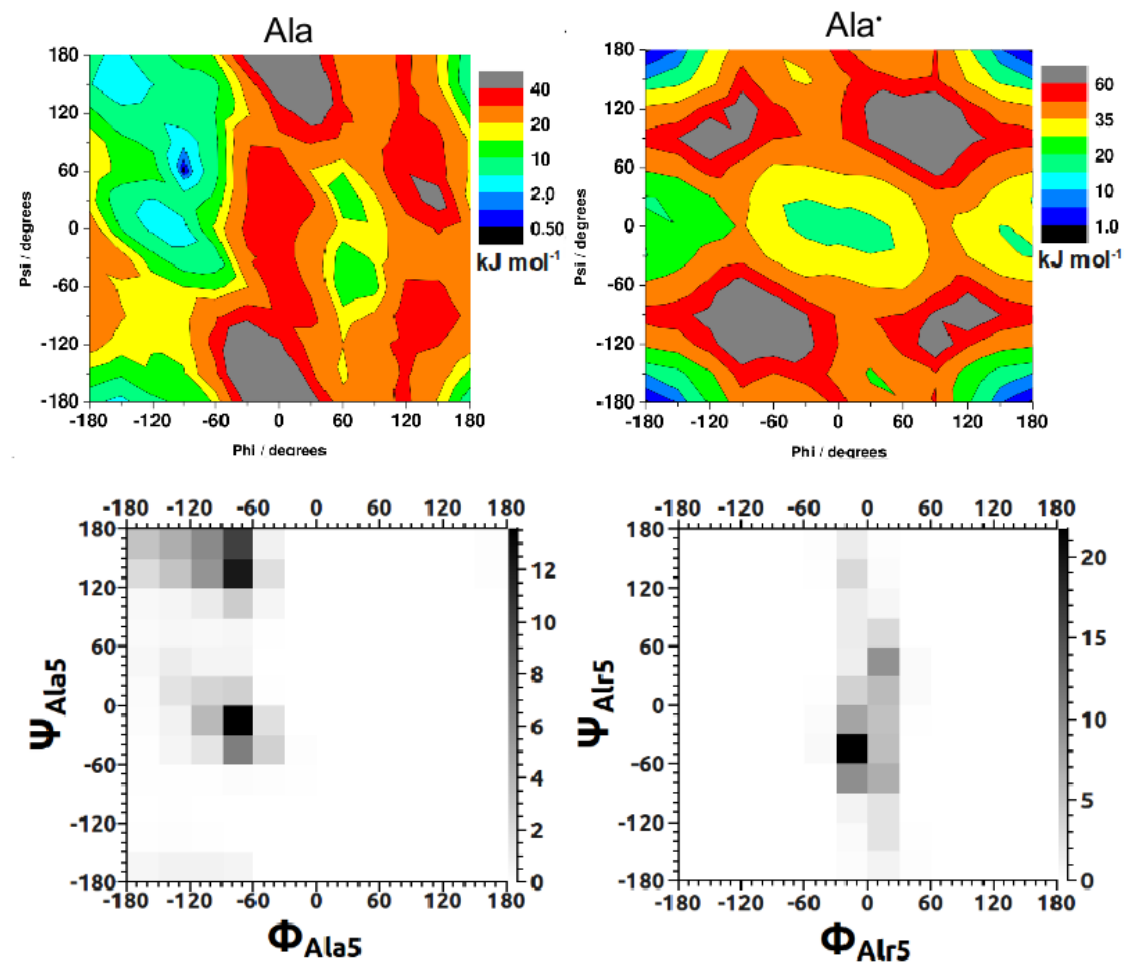

Figure 26. The IUPAC "cut" of the Ala and Ala potential energy surfaces (top) and the density Ramachandran map of the Ala5 and Alr5 residues.

It can be seen that the $\phi$ and $\psi$ angles of the most stable conformers of Ala agree well with the highest populated $\phi$ and $\psi$ angles of the Ala5 structures. The Ramachandran maps and potential energy surfaces show that the L conformational space is both lower in energy and has a larger population of structures than that which can be found in the D conformational space. The agreement between the $\phi$ and $\psi$ angles of the Ala potential energy surface and those of the Alr5 Ramachandran map is not as pronounced as those of Ala and Ala5, largely because the global minimum of the Ala ${ }^{\bullet}$ PES has a relatively low population density in the 
MD simulations. Instead, the minimum in the $\phi$ and $\psi$ equal to zero region has a higher population density. Moreover, the distribution of the population density is wider along the $\psi$ axis of the Alr Ramachandran map despite of the fact that the energy is lower along the $\phi$ axis of the Ala potential energy surface. These differences can be attributed to the tendency of the peptide to form a turn to enable intra-molecular hydrogen bonding and to reduce the solvent accessible surface area of the peptide. It is possible that the intramolecular hydrogen bonding observed in the peptide is more favorable when the $\phi$ angle is near zero degrees than when the $\psi$ angle is near zero degrees. However, the delineation of these and other parameters used to compare the $\phi$ and $\psi$ angles of single amino acids is still under investigation, considering that the solvent and secondary structures can perturb the ideal $\phi$ and $\psi$ angles of single amino acid residues. ${ }^{105-107}$ Both the quantum chemical and MD results presented herein show the conversion of helical $\phi$ and $\psi$ angles to planar $\phi$ and $\psi$ angles after hydrogen atom abstraction, which corresponds to the conformations that are also stabilized by the capto-dative effect. Both the potential energy surfaces from $a b$ initio methods and the Ramachandran maps from the MD simulations show the consequences of this effect on the structure of the $\mathrm{C}^{\alpha}$-centered peptide radical. 


\subsection{CONCLUSIONS}

The PES for the Gly, Gly Ala and Ala structures show the stable conformers for these residues. The Gly and Ala PES each contained 5 minima, which remained similar to the geometries of the respective pre-reaction complexes and transition states in the hydrogen abstraction reaction. Changes to the $\phi$ and $\psi$ angles were shown upon the formation of the post-reaction complexes, which where similar to the structures of the Gly and Ala conformers. The first-order saddle points of the PES showed that the Gly residue loses its flexibility when changed to Gly', whereas the flexibility of Ala and Ala is similar.

The stability of the $\beta_{\mathrm{L}}$ conformer of Gly and Ala radicals was shown in transition state and post-reaction van der Waals complex with the ${ }^{\circ} \mathrm{OH}$ radical. The $\beta_{\mathrm{L}}$ conformer of the Gly and Ala radicals is stabilized by resonance and the capto-dative effect and it is suspected that these factors also influence the stability of the transition state and van der Waals complexes. The $\gamma$ and $\alpha$ conformers of the Gly transition state were of similar energy, whereas the Ala side chain strongly destabilized the $\alpha$ conformers of the transition state structures. This could inhibit the abstraction of hydrogen from residues other than glycine in helical peptides and proteins. Given the similarity between the structures of $\mathrm{H}_{2} \mathrm{O}$ and ${ }^{\circ} \mathrm{OH}$, the structure of the complexes found herein should be similar to the structure of these complexes in the presence of structural water.

The unfolded Gly and Ala residues can be converted to Gly and Ala by $\mathrm{H}_{2} \mathrm{O}_{2}$, since the energy of the system remains well-below the pre- $\mathrm{OH}$ abstraction entrance. The conversion of Gly and Ala to the $\beta$ conformer shown in this work reveals a possible mechanism for the 
${ }^{\circ} \mathrm{OH}$-initiated unfolding of peptides and proteins.

Here it has also been shown how a free radical can initiate the unfolding of a helical peptide. Hydrogen atom abstraction from the $\mathrm{C}_{\alpha}$ of residue 3 of $\mathrm{N}$-Ac-GGGGG-NH $\mathrm{N}_{2}$ and $\mathrm{N}$ Ac-AAAAA- $\mathrm{NH}_{2}$ produces a radical that is stabilized by capto-dative and inductive effects, with no effects shown on the structure neighboring residues. The conformation of both $\mathrm{Ala}^{3}$ and $\mathrm{Gly}^{3}$ becomes more planar, however, the secondary structural elements are conserved. Hydrogen atom abstraction from the amide nitrogen eliminates the hydrogen bond with $\mathrm{Ala}^{1}$, but not $\mathrm{Gly}^{1}$ in the helix and the hydrogen bond within residue 3 in the extended conformation. The structural perturbations of the peptide containing the $\mathrm{C}_{\beta}$ radical are negligible. An increase in the length of the amide bond is shown when the $\mathrm{C}_{\alpha}$ and amide nitrogen radicals are formed, suggestive of a decrease in bond stability, which is not observed when a radical forms at $\mathrm{C}_{\beta}$.

The hydrogen abstraction reaction energies indicate that the $\mathrm{C}_{\alpha}$ radical is the most stable, whereas the radical at the amide nitrogen is the least. The $\Delta \mathrm{G}$ values for the transition from the $3_{10}$-helix to the extended conformation indicated that the unfolding of the peptides with the $\mathrm{C}_{\alpha}$ radical are the most favorable, followed by the those with the radical at the amide nitrogen, whereas the propensity of $\mathrm{A} 5\left(\mathrm{C}_{\beta}\right)_{\mathrm{HEL}}$ to unfold is similar to that of $\mathrm{A} 5_{\mathrm{HEL}}$. The secondary structure of a peptide has a strong influence on the $\mathrm{H}-\mathrm{C}_{\alpha}$ bond, but not the $\mathrm{H}$ $\mathrm{C}_{\beta}$, nor the $\mathrm{N}-\mathrm{H}$, which can protect the protein from radical-initiated hydrogen abstraction. Hydrogen abstraction by ${ }^{\circ} \mathrm{OH}$ radical is the most favorable of the ROS studied, followed by $\mathrm{HO}_{2}{ }^{\bullet}$ and $\mathrm{O}_{2}^{-*}$ 
The unfolding of the pentapeptides shown in the quantum chemical calculations was also shown in the MD simulations. The Ramachandran maps of the central residue of the hepta-alynyl peptide in its closed-shell and radical states were similar to the corresponding potential energy surfaces of the Ala and Ala diamides. These representations showed that planar conformations of the radicals were the most stable and the most abundant in the radical and distinct from the stable and abundant conformations of the closed-shell residue, which populated the more stable L conformations. Long-range interactions that stabilize turn structures are possible reasons for the differences shown between the representations of the radical, however future work could delineate the effect of long range interaction on peptide structures.

The thermodynamic cycles of A5 and G5 indicate that the conversion of the peptide helices to $\mathrm{A} 5_{\mathrm{EXT}}{ }^{\cdot}$ or $\mathrm{G} 5_{\mathrm{EXT}}{ }^{\circ}$ or are exergonic, exothermic and entropically favorable. Therefore, the radical-initiated unfolding of $\mathrm{A} 5_{\mathrm{HEL}}$ and $\mathrm{G} 5_{\mathrm{HEL}}$ is endothermic when initiated by ${ }^{\circ} \mathrm{OH}$ and terminated by a reducing agent.

This work provides new insight into the unfolding mechanism of peptides in the cellular condition known as oxidative stress. 


\subsection{REFERENCES}

1. Falkowski, P. G. Science 2006, 311, 1724-1725.

2. $\quad$ Raymond, J.; Segré, D. Science 2006, 311, 1764-1767.

3. Goldfine, H. J. Gen. Physiol. 1965, 49, 253-274.

4. Cohen, S. M. Environ. Health Perspect. 1983, 50, 51-59.

5. Kobliashev, V. A. Biochemistry (Moscow) 2010, 75, 675-685.

6. Fatehi-Hassanabad, Z.; Chan, C. B.; Furman, B. L. Eur. J. Pharmacol. 2010, 636, 8-17.

7. Jenner, P. Ann. Neurol. 2003, 53 (Suppl 3), S26-S36.

8. $\quad$ Barnham, K. J.; Masters, C. L.; Bush, A. I. Nat. Rev. Drug Discov. 2004, 3, 205-214.

9. $\quad$ Stadtman, E. R. Free Radic. Res. 2006, 40, 1250-1258.

10. Davies, K. J. A. J. Biol. Chem. 1987, 262, 9895-9901.

11. Fridovich, I. Annu. Rev. Biochem. 1975, 44, 147-159.

12. Halliwell, B.; Gutteridge, M. C. Biochem. J. 1984, 219, 1-14.

13. Spiteller, G. Free Radic. Biol. Med. 2006, 41, 362-387.

14. Dizdaroglu, M. Mutat. Res. 1992, 275, 331-342.

15. Fu, M. X.; Wells-Knecht, K. J.; Blackedge, J. A.; Lyons, T. J.; Thorpe, S. R.; Baynes, J. W. Diabetes 1994, 43, 676-683.

16. Gebicki, J. M.; Nauser, T.; Domazou, A.; Steinmann, D.; Bounds, P. L.; Koppenol, W. H. Amino Acids 2010, 39, 1131-1137.

17. Willix, R. L.; Garrison, W.M. Radiat. Res. 1967, 32, 452-462.

18. Garrison W. M.; Jayco, M. E.; Bennett, W. Radiat. Res. 1962, 17, 341-352.

19. Levine, R. L. J. Biol. Chem. 1983, 258, 11823-11827.

20. Davies, K. J. A.; Delsignore, M. E.; Lin, S. W. J. Biol. Chem. 1987, 262, 9902-9907.

21. Prütz, W. A.; Butler, J.; Land, E. J. Int. J. Radiat. Biol. 1983, 44, 183-196.

22. Schuessler, H.; Schilling, K. Int. J. Radiat. Biol. 1983, 45, 267-281.

23. Davies, K. J. A.; Delsignore, M. E. J. Biol. Chem. 1987, 262, 9908-9913.

24. Barlow, D. J.; Thornton, J. M. J. Mol. Biol. 1988, 201, 601-619.

25. Biron, Z.; Khare, S.; Samson, A. O.; Hayek, Y.; Naider, F.; Anglister, J. Biochemistry 2002, 41, 12687-12696.

26. Venkatachalam, C. M. Biopolymers 1968, 6, 1425-1436.

27. Moretto, A.; Formaggio, F.; Kaptein, B.; Broxterman, Q.B.; Wu, L.; Keiderling, T.A.; Toniolo, C. Biopolymers 2008, 90, 567-574.

28. Toniolo, C. CRC Crit. Rev. Biochem. 1980, 9, 1-44.

29. McPhalen, C. A.; Vincent, M. G.; Picot, D.; Jaonsonius, J. N.; Lesk, A. M.; Chothia, C. J. Mol. Biol. 1992, 227, 197-213.

30. Gertstein, M; Chothia, C. J. Mol. Biol. 1991, 220, 133-149.

31. Singh, Y.; Sharpe, P. C.; Hoang, H. N.; Lucke, A. J.; McDowall, A. W.; Bottomley, S. P.; Fairlie, D. P. Chem. Eur. J. 2011, 17, 151-160.

32. Armstrong, D. A.; Yu, D.; Rauk, A. Can. J. Chem. 1996, 74, 1192-1199.

33. Chass, G. A.; Sahai, M.; Law, J. M. S.; Lovas, S.; Farkas, O.; Perczel, A.; Rivail, J. L.; Czismadia, I. G. Int. J. Quant. Chem. 2002, 90, 933-968. 
34. Jorgensen, W. L.; Maxwell, D. S.; Tirado-Rives, J. J. Am. Chem. Soc. 1996, 118, 11225-11236.

35. Maxwell, D. S.; Tirado-Rives, J.; Jorgensen, W. L. J. Comp. Chem. 1995, 16, 9841010.

36. Kaminski, G.; Friesner, R. A.; Tirado-Rives J.; Jorgensen, W. L. J. Phys. Chem. B 2001, 105, 6474-6487.

37. Lifson, S.; Warshel, A. J. Chem. Phys. 1968, 49, 5116-5129.

38. Szőri, M.; Fittschen, C.; Csizmadia, I. G.; Viskolcz, B. J. Chem. Theory Comput. 2006, 2, 1575-1586.

39. Sousa, S. F.; Fernandes, P. A.; Ramos, M. J. J. Phys. Chem. A 2007, 111, 10439-10452.

40. Speck, E. J.; Olson, A.; Zhengshuang, S.; Kallenbach, N. R. J. Am. Chem. Soc. 1999, 121, 5571-5572.

41. Chou, P. Y.; Fasman, G. D. J. Mol. Biol. 1977, 115, 135-175.

42. Rauk, A.; Yu, D.; Armstrong, D. A. J. Am. Chem. Soc. 1997, 119, 208-217.

43. Rauk, A.; Yu, D.; Taylor, J.; Shustov, G.; Block, D.; Armstrong, D. Biochemistry 1999, 39, 9089-9096.

44. Galano, A.; Alvarez-Idaboy, J. R.; Montero, L. A.; Vivier-Bunge, A. J. Comput. Chem. 2001, 22, 1138-1153.

45. Galano, A.; Alvarez-Idaboy, J. R.; Bravo-Pérez, G.; Ruiz-Santoyo, M. E. J. Mol. Struct. (THEOCHEM) 2002, 617, 77-86.

46. Huang, M. L.; Rauk, A. J. Phys. Org. Chem. 2004, 17, 777-786.

47. Zhu, R.; Lin, M. J. Phys. Chem. A 2001, 105, 6243-6248.

48. Chersakov, A.; Jonsson, M. J. Chem. Inf. Comput. Sci. 2000, 40, 1222-1226.

49. MacInnes, I.; Walton, J. C.; Nonhebel, D. C. J. Chem. Soc. Chem. Commun. 1985, 712713.

50. Viehe, H.-G.; Janousek, Z.; Mirnyi, R; Stella, L. Acc. Chem. Res. 1985, 18, 148-154.

51. Owen, M. C.; Viskolcz, B.; Csizmadia, I. G. J. Phys. Chem. B 2011, 115, 8014-8023.

52. Owen, M. C.; Viskolcz, B.; Csizmadia, I. G. J. Chem. Phys. 2011, 135, 035101.

53. Tannor, D. J.; Marten, B.; Murphy, R.; Friesner, R. A.; Sitkoff, D.; Nicholls, A.; Ringnalda, M.; Goddard III, W. A.; Honig, B. J. Am. Chem. Soc. 1994, 116, $11875-$ 11882.

54. Marten, B.; Kim, K.; Cortis, C.; Friesner, R. A.; Murphy, R. B.; Ringnalda, M. N.; Sitkoff, D.; Honig, B. J. Phys. Chem. 1996, 100, 11775-11788.

55. Gaussian 09. Frisch, M. J. et al. Gaussian Inc, Wallingford CT, 2009.

56. Becke, A. D. Phys. Rev. A, 1988, 38, 3098-3100.

57. Becke, A. D. J. Chem. Phys. 1996, 104, 1040-1046.

58. Lee, C.; Yang, W.; Parr, R. G. Phys. Rev. B 1988, 37, 785-789.

59. Li, X.; Frisch, M. J. J. Chem. Theory and Comput. 2006, 2, 835-839.

60. Note that BHandHLYP means $0.5 \times \mathrm{E}_{\mathrm{X}}^{\mathrm{HF}}+0.5 \times \mathrm{E}_{\mathrm{X}}^{\mathrm{LSDA}}+0.5 \times \mathrm{E}_{\mathrm{X}}{ }^{\text {Becke88 }}+\mathrm{E}_{\mathrm{C}}{ }^{\mathrm{LYP}}$ functional.

61. Zhao, Y.; González-García, N.; Truhlar, D. G. J. Phys. Chem. A 2005, 109, 2012-2018.

62. Baboul, A. G.; Curtiss, L. A.; Redfern, P. C.; Raghavachari, K. J. Chem. Phys. 110, 
1999, 7650-7657.

63. Cossi, M.; Rega, N.; Scalmani, G.; Barone, V. J. Comput. Chem. 2002, 24, 669-681.

64. Lu, H. -F.; Li, F. -Y.; Lin, S. H. J. Comp. Chem. 2007, 28, 783-794.

65. Wille, U. J. Org. Chem. 2006, 71, 4040-4048.

66. Szőri, M.; Abou-Abdo, T.; Fittschen, C.; Csizmadia, I. G.; Viskolcz B. Phys. Chem. Chem. Phys. 2007, 9, 1931-1940.

67. Janoscheck, R.; Rossi, M. Int. J. Chem. Kin. 2002, 34, 550-560.

68. Fiser, B.; Szőri, M.; Jójárt, B.; Izsák, R.; Viskolcz, B.; Csizmadia I. G. J. Phys. Chem. B. 2011, 115, 11269-11277.

69. Cossi, M.; Rega, N.; Scalmani, G.; Barone, V. J. Comput. Chem. 2002, 24, 669-681.

70. Bayly, C. I.; Cieplak, P.; Cornell, W. D.; and Kollman, P. A. J. Phys. Chem. 1993, 97, 10269.

71. Cornell, W. D.; Cieplak, P.; Bayly, C. I.; Kollman, P. A. J. Am. Chem. Soc. 1993, 115, 9620-9631.

72 . Cieplak, P.; Cornell, W. D.; Bayly, C.; Kollman, P. A. J. Comp. Chem. 1995, 16, 13571377.

73. Case, D. A. et al. AMBER 8, University of California, San Francisco, 2004.

74. Maestro, version 9.2, Schrödinger, LLC, New York, NY, 2011.

75. Jorgensen, W. L.; Chandrasekhar, C.; Madura, J. D.; Impey, R.W.; Klein, M. L. J. Chem. Phys. 1983, 79, 926-935.

76. Martyna, G. J.; Tobias, D. J.; Klein, M. L. J. Chem. Phys. 1994, 101, 4177-4189.

77. Darden, T.; York, D.; Pedersen, L. J. Chem. Phys. 1993, 98, 10089-10092.

78. Chou, K. Anal Biochem. 2000, 286, 1-16.

79. Rauk, A.; Armstrong, D. A. Fairlie, D. P. J. Am. Chem. Soc. 2000, 122, 9761-9767.

80. Owen, M. C.; Komáromi, I.; Murphy, R. F.; Lovas, S. J. Mol. Struct. 2006, 759, $117-$ 124.

81. Zhu, X.; Koenig, P.; Hoffmann, M.; Yethiraj, A.; Cui, Q. J. Comput. Chem. 2010, 31, 2063-2077.

82. Sekusak, S.; Sabljic, A. Chem Phys Lett. 1997, 272, 353-360.

83. Alvarez-Idaboy J. R.; Mora-Diez N.; Boyd, R. J.; Vivier-Bunge, A. J. Am. Chem. Soc. 2001, 123, 2018-2024.

84. Shaik, S. S.; Hiberty, P. C.; Lefour, J. -M.; Ohanessian G. J. Am. Chem. Soc. 1987, 109, 363-374.

85. Kollmar, H. J. Am. Chem. Soc. 1978, 101, 4832-4840.

86. Katritzky, A. R.; Soti, F. J. Chem. Soc., Perkin Trans 1 1974, 1, 1427-1432.

87. MacInnes, I.; Walton, J. C.; Nonhebel, D. C. J. Chem. Soc., Chem. Commun. 1985, 712-713.

88. Bordwell, F. G.; Zhang, X. J. Org. Chem. 1990, 55, 6078-6079.

89. Stefancic, I.; Bonifacic, M.; Asmus, K.; Armstrong, D.A. J. Phys. Chem. A 2001, 105, 8681.

90. Leissmann, M. H.; Hansmann, B.; Blachly, P. G.; Francisco, J. S.; Abel, B. J. Phys. Chem. A 2009, 113, 7570 . 
91. Hawkins, C. L; Davies, M. J. J. Chem. Soc., Perkin Trans. 1998, 2, 2617-2622.

92. Garrison, W. M. Chem. Rev. 1987, 87, 381-398.

93. Plusquellic, D. F.; Pratt, D. W. J. Phys. Chem. A 2007, 111, 7391-7397.

94. Vystovsky, Y. B.; Bryantsev, V. S. Int. J. Quant. Chem. 2004, 96, 123-135.

95. Rauk, A. Chem. Soc. Rev. 2009, 38, 2698-2715.

96. Allsop, D.; Mayes, J.; Moore, S.; Masad, A.; Tabner, B. J. Biochem. Soc., Perkin Trans 1 2008, 36, 1293-1298.

97. Easton, C. J. Chem. Rev. 1997, 97, 53-82.

98. Sperling, J.; Elad, D. J. Am. Chem. Soc. 1971, 93, 3839-3840.

99. Elad, D.; Sinnreich, J. J. Chem. Soc. Chem. Commun. 1965, 471-472.

100. Doan, H. Q.; Davis, A. C.; Francisco, J. S. J. Phys. Chem. A 2010, 114, 5342-5357.

101. Berkowitz, J.; Ellison, G. B.; Gutman, D. J. Phys. Chem. 1994, 98, 2744-2765.

102. Eakin, C. M.; Berman, A. J.; Miranker, A. D. Nat. Struct. Mol. Biol. 2006, 13, 202-208.

103. Kellogg, E. W. $3^{\text {rd }}$; Fridovich, I. J. Biol. Chem. 1975, 250, 8812-8817.

104. Viskolcz, B.; Csizmadia, I. G.; Knack Jensen, S. J.; Perczel, A. Chem. Phys. Lett. 2010, 501, 30-32.

105. Tosatto, S. C.; Battistutta R. BMC Bioinformatics 2007, 8, 155.

106. Malkov, S. N.; Zivkovic, M. V.; Beljanski, M. V.; Hall, M. B.; Zaric, S. D. J. Mol. Model. 2008, 14, 769-775.

107. Beck, D. A. C.; Alonso, D. O. V.; Inoyama, D.; Daggett, V. Proc. Natl. Acad. Sci. U.S.A. 2008, 105, 12259-12264. 


\subsection{ACKNOWLEDGEMENTS}

I thank my supervisor, Professor Béla Viskolcz for giving me the opportunity to earn my $\mathrm{PhD}$ in his laboratory. I am grateful for his guidance and encouragement and providing an excellent work environment. I also thank Professor Imre Csizmadia for his guidance and for inspiring me over the course of ten years of studentship. I could not have received two better teachers as mentors, and for this I am very grateful. I also thank Professor Gregory A. Chass for his mentoring during these years.

I thank Professor István Marsi, Dr. Laszló Seres, Dr. Milán Szőri, Dr. Balázs Jójart, Dr. Szilárd Fejer, Béla Fiser, Laszló Müller, Máté Labadi and DongJin Lee for their technical expertise and for welcoming me into their research group.

I thank my past colleagues at Creighton University, Dr. Zsolt Bozsó, Dr. Atilla Borics, Dr. Krisztina Heredi-Szabó, Dr. Shawn Ahmed, Dr. Jeffrey Copps and Dr. Nicholas Palermo. I thank my parents, Winston Owen and Joyce Owen, my brother, Marlon Owen, and the rest of my family.

I thank Benjamin Currall, Anthony Florita, Kristin Woodley, Marsha Haynes, Andrew Court, Jason Palmer, Joseph Leo, Terry Wortman, Amanda Millemon, and others whom I have not mentioned, for their friendship. 


\section{APPENDIX A - PUBLICATION LIST}

\section{Publications related to this dissertation}

M. C. Owen, I. Komáromi, R. F. Murphy, S. Lovas. The conformational preference of $\mathrm{C}^{\alpha}$ centered radicals in proteins. Journal of Molecular Structure. (Theochem) 759, (2006) 117 124.

M. C. Owen, B. Viskolcz and I. G. Csizmadia. Quantum chemical analysis of the unfolding of a penta-alanyl $3_{10}$-helix initiated by $\mathrm{HO}^{\circ}, \mathrm{HO}_{2}{ }^{\circ}$ and $\mathrm{O}_{2}{ }^{-} \mathrm{J}$. Phys. Chem. B 115, (2011) 8014-8023

M. C. Owen, B. Viskolcz and I. G. Csizmadia Quantum chemical analysis of the unfolding of a penta-glycyl $3_{10}$-helix initiated by $\mathrm{HO}^{\bullet}, \mathrm{HO}_{2}{ }^{-}$and $\mathrm{O}_{2}^{-}{ }^{-} \mathrm{J}$. Chem. Phys. 135, (2011) 035101 .

M. C. Owen, Milán Szőri, Imre G. Csizmadia and Béla Viskolcz. Conformation-Dependent - $\mathrm{OH} / \mathrm{H}_{2} \mathrm{O}_{2}$ Hydrogen Abstraction Reaction Cycles of Gly and Ala Residues: A Comparative Theoretical Study. J. Phys. Chem. B 2011 DOI: 10.1021/jp2089559.

M. C. Owen, I. Komáromi, B. Jojárt, I. G. Csizmadia and B. Viskolcz. The development of alanyl radical parameters for the OPLS-AA/L force field. J. Chem Theory Comput. (Submitted)

\section{Other publications}

M. C. Owen, M. Szőri, B. Jojárt, B. Viskolcz, I. G. Csizmadia. Conformational and Thermodynamic Analysis of the COXIB Scaffold Using Quantum Chemical Calculations. International Journal of Quantum Chemistry, (2011). DOI: 10.1002/qua.23049

I. Komáromi, M.C. Owen, R.F. Murphy, S. Lovas. Development of glycyl radical parameters for the OPLS-AA/L force field. Journal of Computational Chemistry 29, (2008) 1999-2009.

N.Y. Palermo, J. Csontos, M.C. Owen, R.F. Murphy, S. Lovas. Aromatic-backbone interactions in model $\alpha$-helical peptides. Journal of Computational Chemistry 28, (2007) 1208-1214.

T.A. Pecora, M.C. Owen, C.N.J. Marai, D.H. Setiadi, G.A. Chass. Bridging the gap between pure science and the general public: comparison of the informational exchange for these extremities for scientific awareness. Journal of Molecular Structure. (Theochem) 666-667, (2003) 699-706. 


\section{ÖSSZEFOGLALÓ}

A disszertációban azt mutatjuk meg, hogy peptidekben kialakuló szabadgyök centrum, hogyan befolyásolja a peptidek másodlagos szerkezetét, és milyen szerkezeti változásokat tud indukálni.

Annak eldöntésére, hogy a glicin pro-L hidrogénatomját lehet-e könnyebben leszakítani, mint az ugyanolyan pozícióban lévő alanin hidrogénjét, a reakció kiindulási van der Waals komplexeinek, átmeneti állapotainak és a reakció utáni van der Waals komplexeinek szerkezet és energiáit számítottuk a $\beta_{L}, \gamma_{L}, \gamma_{D}, \alpha_{L}$ és $\alpha_{D}$ konformerekre MPWKCIS1K/6-311++G(3df,2p)//BHandHLYP/6-311+G(d,p) elméleti szinten.

A helikális szerkezetek $\mathrm{HO}^{*}, \mathrm{HO}_{2}{ }^{*}$ és $\mathrm{O}_{2}^{-{ }^{-}}$gyökök által indukált letekeredésének (unfolding) mechanizmusát (1. ábra) a különböző pozíciókból történő hidrogén absztrakciós reakciók segítségével, valamint a reakciók termodinamikájának számolásával derítettük fel. Ehhez modell peptidekben a középső aminosavakból képzett $\mathrm{C}_{\alpha}$ és amid nitrogénen kialakuló gyököket vizsgáltuk a G5 ( $N$-Ac-GGGGG-NH${ }_{2}$ ), valamint a $\mathrm{C}_{\alpha}, \mathrm{C}_{\beta}$ és amid nitrogénen centrált gyököket az A5 (N-Ac-AAAAA- $\left.\mathrm{NH}_{2}\right)$ esetekben a sürüségfunkcionál elmélet felhasználásával. A potenciális energia-, standard entalpia-, standard szabadentalpia- és standard entrópiaváltozásokat a reakciók során a B3LYP /6-31G(d) és B3LYP/6-311+G(d,p) elméleti szinteken számoltuk ki a G5 és A5 peptidekre, azok $3_{10}$-helikális és teljesen nyújtott struktúráin, követve az absztrakciós reakciót, mind gáz fázisban, mind pedig CPCM implicit vízmodell alkalmazásával.

Ahhoz, hogy az $\alpha$ szénatomon létrejövő szabad gyök hatását hosszabb peptidekben és fehérjékben lehessen szimulálni, hosszabb futási idejü molekula dinamikai (MD) számolásokat alkalmazhatunk. Az Ala-ból képződő szabad gyökre új paramétereket fejlesztettünk ki az OPLS-AA erőtérhez a kvantumkémiai és az OPLS-AA potenciálenergiahiperfelületek különbségének minimálásával. Ezt az új paraméter készletet használtuk MD szimuláció során, hogy felderítsük az $\alpha$ szénatomon létrejött szabad gyök hatását a heptaalanin peptid konformációjára. A Gly és Ala konformereiben történő szabadgyök-képződés 


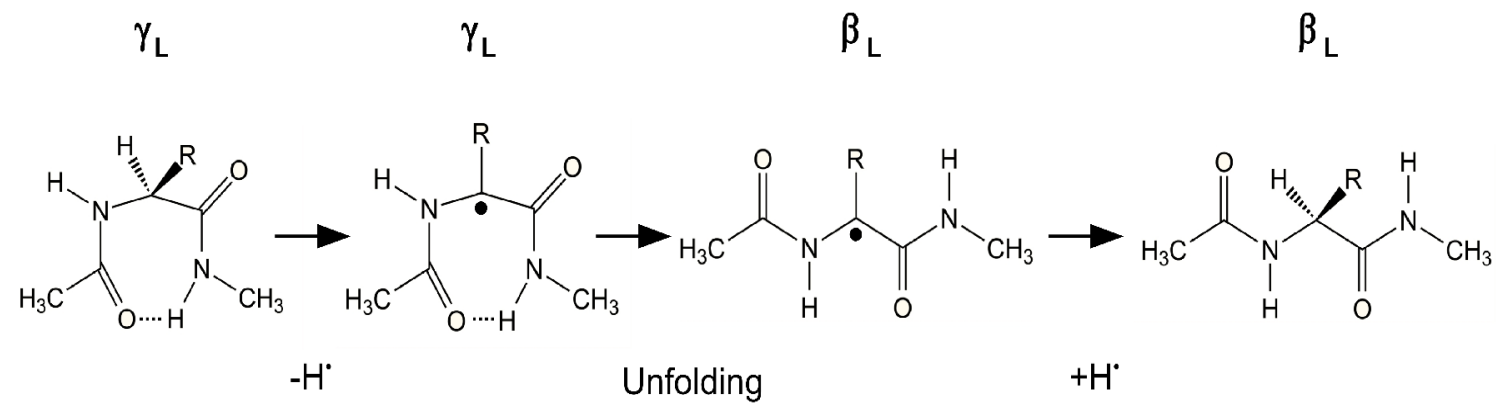

1. ábra. Egy aminosav részegységnek szabad gyök inicializált letekeredése sémája.

során jelentősen megváltozik a konformáció, és ezt a változást mindegyik aminosavegység konformereire követni lehet a legkisebb energiájú úton keresztül (kiszámolva a belső reakciókoordinátát). A H-elvonási reakciókban a Gly és az Ala $\beta_{\mathrm{L}}$ konformereinek átmeneti állapota (TS) rendelkezik a legkisebb relatív energiával. A TS-ekben az Ala oldallánca jelentősen destabilizálja az $\alpha$ konformereket a $\gamma$ konformerekhez képest. Lényeges különbség az Ala-tól, hogy a Gly esetében az $\alpha$ és $\gamma$ konformerek H-elvonási reakcióinak aktiválási energiája nem különbözik jelentősen. Ez a szerkezeti hatás gátolja a fehérjék hélixeiben a királis aminosavakból történő hidrogénelvonási reakciót. A gyökképződést követő H-elvonás átmeneti állapota a $\mathrm{H}_{2} \mathrm{O}_{2}$ és $\mathrm{Ala}{ }^{*}$, ill. Gly reakciójában is mintegy $90 \mathrm{~kJ} \mathrm{~mol}^{-1}$-lal alacsonyabban fekszik, a kezdeti lépéshez viszonyítva. Ez azt sugallja, hogy a hidoxil gyök képes $\alpha \rightarrow \beta$ átmenetet okozni egy aminosav szekvenciában, miután a peptidgyök pl. a $\mathrm{H}_{2} \mathrm{O}_{2}$ segítségével normál peptiddé alakul vissza.

A G5 és A5 pentapeptidek esetén megmutattuk, hogy a H-elvonási reakció az $\alpha$ szénatomon a legkedvezőbb, majd a $\beta$-szénatomon, és utána az amid nitrogénen. $\mathrm{A} H-\mathrm{C}_{\alpha}$ kötés disszociációs energiájára nagy hatással van a peptid másodlagos szerkezete, de ez a hatás nem figyelhető meg a $\mathrm{H}-\mathrm{CH}_{2}$ és $\mathrm{H}-\mathrm{N}$ kötések esetén. A $\mathrm{HO}$ ' gyök a legerősebb hidrogénelvonó ágens, ezt követi a $\mathrm{HO}_{2}{ }^{*}$ és végül az $\mathrm{O}_{2}{ }^{-}$. Másodlagos szerkezeti elemek, mint például a hidrogénhidak a $3{ }_{10}$-hélixben, védelmet nyújtanak a gyökökkel szemben, gátolva a kialakuló elektron-delokalizációt az $\alpha$-szénatomon. Ezzel szemben a nyújtott szerkezet a 
gyökcentrum és a szomszédos peptidkötések delokalizációját segít elő. Az $\alpha$-szénatomon létrejött szabad gyökök jelentősen elősegítik a pentapeptidek letekeredését a zárt elektronszerkezetü pentapeptidekkel szemben. Megmutattuk, hogy csak a HO` képes a pentapeptidek nyújtott szerkezetté történő letekeredését inicializálni, és az $\alpha$-szénatomon létrejött szabad gyökök miatt könnyebben letekeredik a G5 mint az A5.

Az újonnan kifejlesztett OPLS-AA torziós paraméterek jó egyezést mutattak az LMP2CCpVTZ(-f) hiperfelülettel, míg a kovalens kötés paraméterei elhanyagolható mértékben változtak az illesztés során. Az új paraméterezéssel végzett MD szimulációk azt mutatták, hogy az $\alpha$-szénatomon levő gyökcentrumot tartalmazó aminosav (Alr) a nyújtott konformációt kedveli, és ezek a konformációk megnövelik a $\gamma$-, $\alpha$ - és $\pi$-turn-ok (kanyarok) számát, attól függően, hogy a szabad gyök melyik aminosavon található. A magasabb rendü struktúrákat destabilizálja az Alr gyök jelenléte, kivéve, amikor ez az aminosav a $3{ }_{10}$-hélix "i +1"-edik pozíciójában található.

Eredményeink egy új értelmezést adnak a fehérjék hibás felcsavarodási mechanizmusára, amiket a fehérjék részegységeinek $\alpha$-szénatomról történő hidrogénelvonása idéz elő. 